\title{
Tectonics controls on fluvial landscapes and drainage development in the westernmost part of Switzerland: Insights from DEM-derived geomorphic indices
}

\author{
Omar M.A. Radaideh*, Jon Mosar \\ Unit of Earth Sciences, Department of Geosciences, University of Fribourg, Switzerland
}

\section{A R T I C L E I N F O}

\section{Keywords:}

Fluvial landscape

Geomorphic anomalies

Geomorphic indices

Hypsometry

Inherited faults

Reactivation

\begin{abstract}
A B S T R A C T
This work focuses particularly on the geomorphological evidence for the tectonic controls on the development of the present-day fluvial landscapes in the westernmost part of Switzerland. The tectonic deformation was evaluated on the basis of a combined analysis of several classical geomorphic indices (hypsometric curves and integrals, transverse topographic symmetry index, and channel's bottom gradients) through high-precision DEM processing. A new optimization strategy was applied for defining geomorphic anomalies related to tectonic activity along the channels of three rivers, based on a combined investigation of topographic swath, longitudinal profiles, geological and geophysical observations. The results show that the abnormally high values of hypsometric integral are spatially occurred on the hanging walls of thrust faults, while abnormally low ones are spatially observed in the same locations of paleo-ice stream pathways. Observations obtained from transverse topographic symmetry index display asymmetries in the most of the studied drainage basins with a predominant SE direction of lateral migration. This direction is in agreement with the dominant dip-direction of the bedding planes within the study area. Abnormal changes in the channel's bottom gradients, which almost coincide in space with pronounced change in the depth of the subsurface geologic layers and in the geophysical properties, are marked by distinct topographic relief in areas where rivers flow above blind and emergent faults. Our analysis not only confirms that there is a significant tectonic control on the evolution of drainage systems, but also revealed a possible evidence for the reactivation of some inherited faults.
\end{abstract}

\section{Introduction}

The development of Earth's landscapes in tectonically active areas is the result of dynamic interactions between tectonic processes that induce vertical and horizontal ground movement, and erosive processes that depend mainly on the lithology and climate among different factors (Armitage et al., 2011; Bishop and Shroder, 2000; Burbank and Anderson, 2001; Champagnac et al., 2012; Hartley et al., 2011; Norton et al., 2010a; Trauerstein et al., 2013; Vernon et al., 2009; Whipple, 2004, 2009; Whittaker, 2012). These interactions have a unique fingerprint in the development and evolution of topographic landforms and fluvial systems (Wobus et al., 2006). In other words, the landscapes contain important archival information of the rates and spatial distribution of deformation and erosion (Armitage et al., 2011; Kirby and Whipple, 2012). Quantitative analysis of such landscapes by using geomorphic indices can therefore provide valuable information about the genetic link between tectonic and erosion processes, which is an issue of modern tectonic geomorphology (Mayer, 1986), and help recognize late Quaternary tectonic movement (Brookfield, 1998; Delcaillau, 2001; El Hamdouni et al., 2007; Gao et al., 2016; Harvey et al., 2015; Hoke et al., 2007; Jackson et al., 1998; Keller and Pinter, 2002; Vojtko et al., 2011).

The Central European Alps region (Fig. 1a), which formed as a result of the collision between the European and African tectonic plates since late Cretaceous times (Schmid et al., 1996), is one of the most important key areas to study the nature of intra-plate compressional deformations (e.g., Kley and Voigt, 2008; Ziegler, 1987; Ziegler et al., 1995) and represents an ideal laboratory to describe feedback mechanisms between tectonic forcing and surface erosion (Champagnac et al., 2009; Madritsch et al., 2009; Schlunegger and Hinderer, 2002; Willett et al., 2006). The present-day landscapes of this region and its northern foreland basin were significantly shaped by several climatic, geological and geomorphical processes, such as glacial erosion, landslides, and debris flows (e.g., Fiore, 2007; Kelly et al., 2004; Korup,

\footnotetext{
* Corresponding author at: Unit of Earth Sciences, Department of Geosciences, University of Fribourg, Chemin du Musée 6, CH - 1700 Fribourg, Switzerland.

E-mail addresses: omar.radaideh@unifr.ch, o.sabbah@ymail.com (O.M.A. Radaideh).
} 


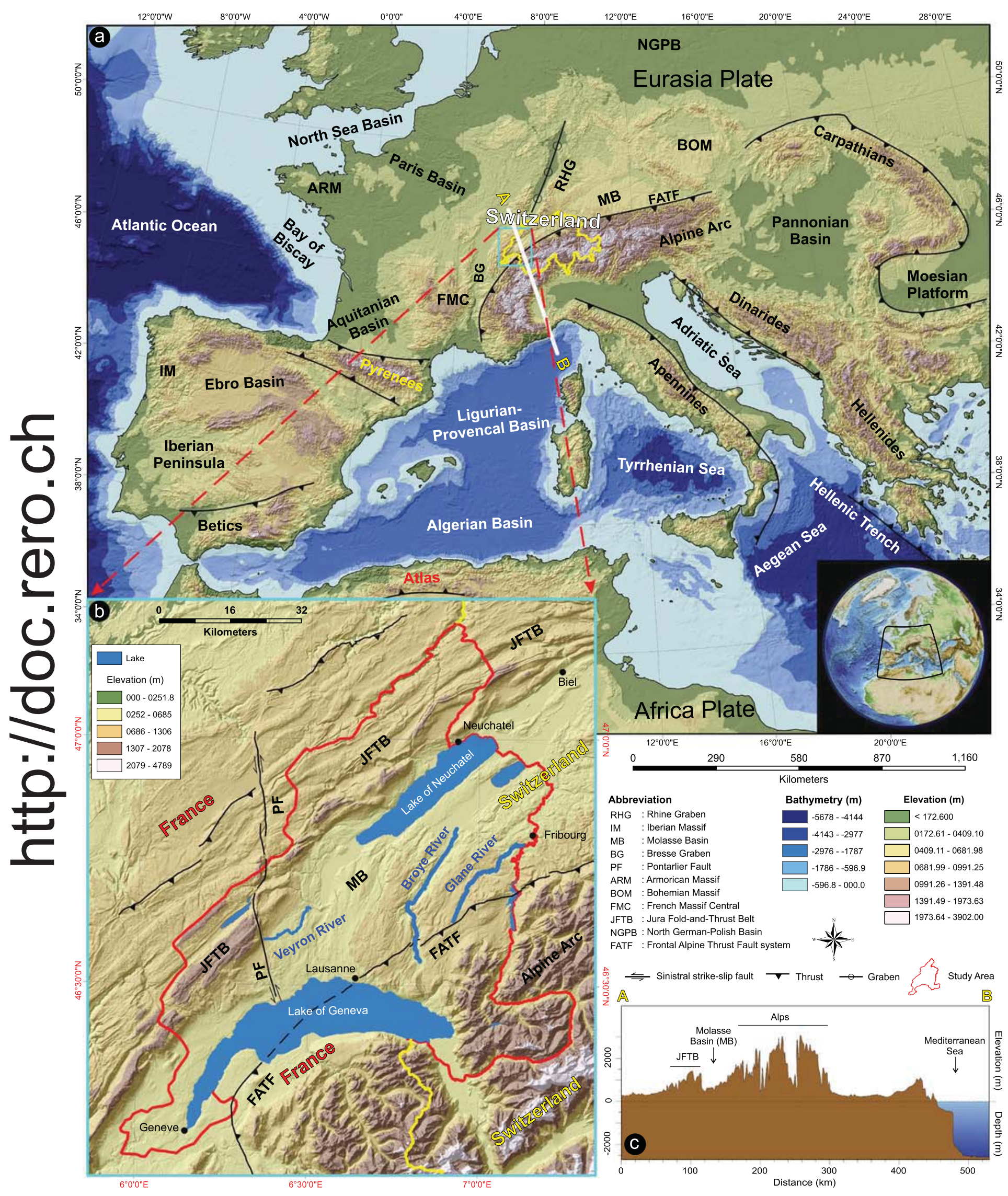

(caption on next page) 
Fig. 1. Geodynamic settings of central and western parts of Mediterranean Basin and surrounding region. (a) Central and western parts of Mediterranean Basin showing the major plate boundaries (Africa and Eurasia), major tectonic systems, and orogenic belts. Insert box in the lower-right corner of the map showing the location of the Mediterranean Basin and surrounding areas. (b) The westernmost area of Switzerland and surrounding regions showing the location of the studied rivers (Broye, Glane, and Veyron). (c) Topographic cross-section showing major topographic features, as well as the change of elevation along a white line A-B in (a). Digital elevation model (30 and 90 m DEMs), global hill shading image (Becker et al., 2009), and bathymetry datasets are provided by the European Environment Agency, e- Atlas, and EMODnet Bathymetry.

2006; Norton et al., 2010a; Salcher et al., 2014; Schlunegger and Hinderer, 2003; Schlunegger and Norton, 2013; Valla et al., 2011). While several studies have already highlighted the impacts of climate (Claude et al., 2019; Delunel et al., 2014; Norton et al., 2010a \& 2010b; Schlunegger and Hinderer, 2003; Schlunegger and Norton, 2013), hillslope (Korup, 2006; Schlunegger, 2002), tectonic uplift (Giamboni et al., 2004; Korup and Schlunegger, 2008; Madritsch et al., 2009, 2010; Persaud and Pfiffner, 2004), bedrock orientation (Chittenden et al., 2013; Nunes et al., 2015), and bedrock erodibility (Dürst-Stucki and Schlunegger, 2013; Korup and Schlunegger, 2008; Kühni and Pfiffner, 2001; Stutenbecker et al., 2015, 2016) on the evolution of Alpine landscapes, and/or on denudation rates, no comprehensive analysis of several geomorphic indices has yet been made to clearly explore how the tectonic controls on fluvial landscape development. Thus, the link between tectonics and fluvial landscapes remains rather unclear.

The availability of high-quality digital elevation data, together with the presence of a large variety of tectonic features (i.e., fault zones and fold systems) and the significant spatial variability of topography make the western part of Switzerland (Fig. 1b) a suitable area to conduct morphotectonics analysis. A quite different approach is applied here, based mainly on the combined analysis of several geomorphic indices of the drainage systems. Our hypothesis is that tectonic movements along faults cause substantial topographic and fluvial geomorphic modifications; namely, lateral tilting of the ground surface, topographic rejuvenation, as well as remarkable anomalies in drainage patterns (e.g., abnormal change in the gradients of river channel and a sudden shift in river channel position). We have tested this hypothesis by using (i) hypsometry (area-altitude analysis) that is an effective indicator to quantify uplift and erosion rates of a landscape (Demoulin, 2010; Hurtrez et al., 1999a, 1999b; Montgomery et al., 2001; Pérez-Peña et al., 2009; Sternai et al., 2011; Strahler, 1952; Willgoose and Hancock, 1998); (ii) Transverse Topographic Symmetry Index (TTSI) that is commonly used to identify areas of a possible tectonic tilting (Cox, 1994; Cox et al., 2001; Keller and Pinter, 2002; Tsodoulos et al., 2008); and (iii) longitudinal profiles based on channel's bottom elevation and gradient that are useful to assess short-term tectonic activity (Chen et al., 2003; Delcaillau et al., 2011; Demoulin, 2010; Font et al., 2010; Hack, 1973). The profiles constructed along the courses of three rivers (Broye, Glane, and Veyron, Fig. 1b) are also supported by topographic-swath profiles and available geological and geophysical information. The strategy of such combinations is to add important constraints on the origin of any possible geomorphic anomaly and to see whether such anomalies can be attributed to tectonic or any other potentially influencing causes. However, it has been proved that tectonics can't always be straightforward, and other factors, particularly deferential erosional strength of the bedrock, glaciation, and hillslope processes, can also induce considerable modifications in the fluvial landscapes (Brocklehurst and Whipple, 2001, 2004; Cox, 1994; Garrote et al., 2006; Hack, 1973; Korup, 2006; Korup et al., 2010; Lifton and Chase, 1992; Norton et al., 2010a; Schlunegger, 2002; Seeber and Gornitz, 1983; Stutenbecker et al., 2016). Based on the above hypothesis, this study aims to quantify the spatial imprints of tectonic deformation on the development of the present-day topographic landscapes and the drainage systems of the northern Alpine foreland in the western part of Switzerland.

\section{General geological and geographical setting}

The Swiss Alps and northern Alpine foreland areas have been the subject of several neotectonic studies. These studies are mainly based on seismicity and stress indicators (e.g., Cloetingh et al., 2006; Diehl et al., 2018; Marschall et al., 2013; Maurer et al., 1997; Ustaszewski and Pfiffner, 2008), on geodetic observations (e.g., Cloetingh et al., 2006; Kahle et al., 1997; Schlatter et al., 2004; Schlunegger and Hinderer, 2002; Wittmann et al., 2007) and on different geological archives that include active faults, lake deposits, slopes, and caves (Becker et al., 2002, 2005; Lemeille et al., 1999; Monecke et al., 2006). The area of investigation is part of the northern foreland of the Swiss Alps and is situated on either side of the water divide between Rhine and Rhone river systems. It covers an area of $5136.6 \mathrm{~km}^{2}$ and lies completely in the westernmost corner of Switzerland between latitudes $46^{\prime} 08^{\prime} 49^{\prime \prime} \mathrm{N}$ and $47^{\circ} 14^{\prime} 19^{\prime \prime} \mathrm{N}$ and longitudes $5^{\circ} 57^{\prime} 35^{\prime \prime} \mathrm{E}$ and $7^{\circ} 17^{\prime} 05^{\prime \prime} \mathrm{E}$. It characterized by abrupt changes in topography with elevation ranges from $\sim 400 \mathrm{~m}$ to $\sim 2500 \mathrm{~m}$. It consists of the exposed record of Triassic to Quaternary rocks (Fig. 2), and is mainly characterized by the presence of widespread strike-slip faults and fold - thrust belt structures. From a tectonic viewpoint, the study area mainly consists of three large-scale zones, namely: the Jura fold-and-thrust belt, the Molasse Basin, and the Prealpes Klippen belt.

The Jura fold-and-thrust belt represents a classic thin-skinned, fold and thrust belt, where a thin Mesozoic sedimentary cover deformed (folded and thrusted) above décollement by "distant push" (Affolter and Gratier, 2004; Burkhard, 1990; Buxtorf, 1907; Laubscher, 1986, 1992; Madritsch et al., 2008; Mosar, 1999; Sommaruga, 1997, 1999). The Jura fold-and-thrust belt, which has a crescent-like shape, is generally divided into three main sectors, which are from north to south: AvantMonts, the External Jura, and the Internal Jura (Sommaruga, 1997, 1999). The tectonic evolution of the Swiss Molasse Basin is tectonically linked to the formation of the Jura fold-and-thrust belt (Burkhard and Sommaruga, 1998; Gorin et al., 1993; Mosar, 1999; Pfiffner et al., 1997; Signer and Gorin, 1995; Sommaruga, 1997, 2011). It is tectonically subdivided into the Plateau Molasse, and the imbricated Subalpine Molasse. The Plateau Molasse presents areas of relatively little deformation between the Jura fold-and-thrust belt and the Subalpine Molasse. It is dominated by low-amplitude northeast-trending folds, and several reverse and strike-slip faults with N-S, NW-SE and WNW-ESE trends (Sommaruga, 1997). The strata are characterized by nearly flat or gentle dips in the areas of Plateau Molasse, but are progressively more tilted toward the Subalpine Molasse. The latter represents a narrow deformation zone composed of thrust sheets of Cenozoic rocks that were overthrust by the Penninic Prealpine Klippen and Helvetic nappes (Pfiffner et al., 1997; Pfiffner, 2014). The Swiss Molasse basin consists essentially of four lithostratigraphic units: the Lower Marine Molasse and the Lower Freshwater Molasse, which together form the first sedimentary sequence of Oligocene to early Miocene age, and the Upper Marine Molasse and the Upper Freshwater Molasse, which together form the second sedimentary sequence of Miocene age (Pfiffner et al., 1997; Schlunegger et al., 1997a, 1997b). The south-eastern corner of the study area is marked by the Prealpes Klippen nappe (Fig. 2a), which consists of several lithologies (Matzenauer, 2012). 
a

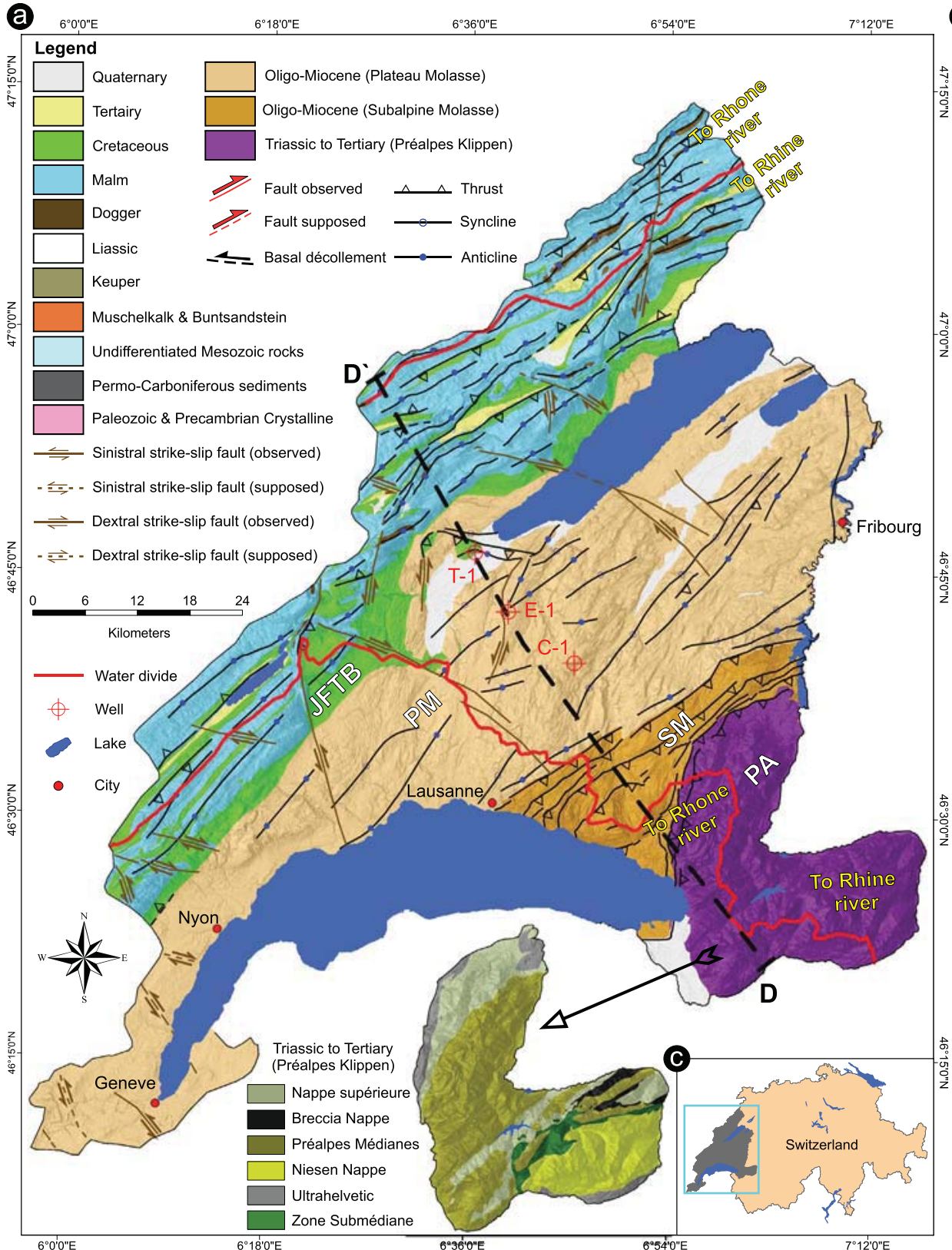

b

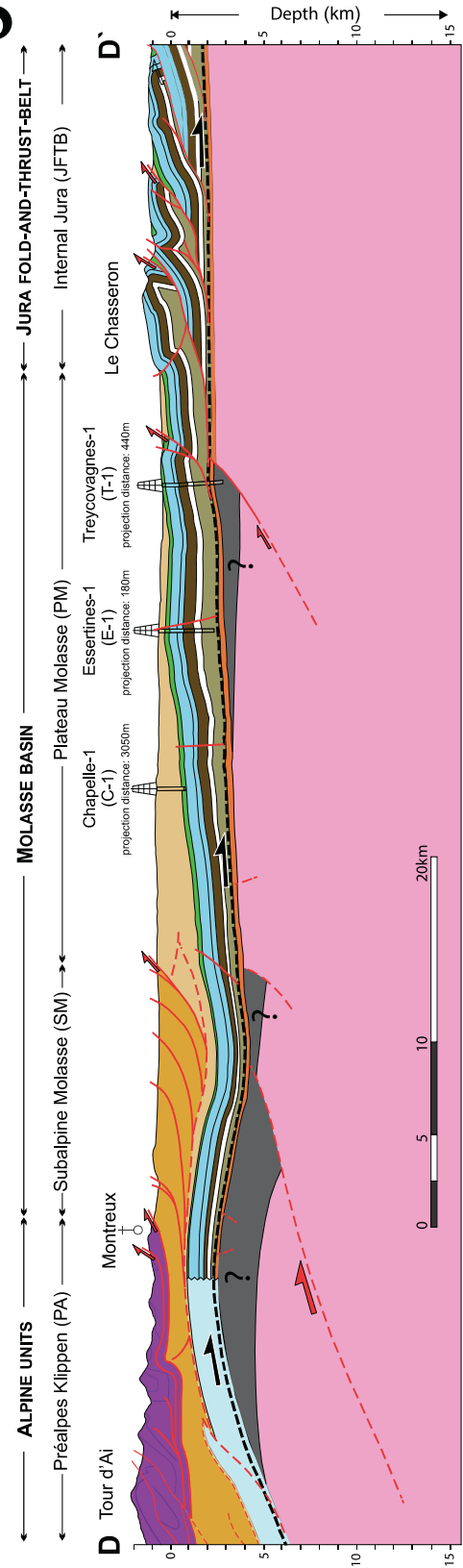

Fig. 2. (a) Simplified geological and structural map of the study area in the westernmost part of Switzerland. Geological data provided by the Swiss Federal Office of Topography (Swisstopo). Structural elements map was compiled by Gruber (2017). (b) General geological cross-section across Jura Fold-and-Thrust-Belt (JFTB), Plateau Molasse (PM), Subalpine Molasse (SM), and Préalpes (PA). The location of the cross-section is marked by a dashed black line D-D' in (a). Cross-section based on Burkhard and Sommaruga (1998), Gruber (2017), Madritsch et al. (2008), Mosar (1999), and Rigassi and Jaccard (1995). (c) Location map of the study area.

\section{Materials and methods}

\subsection{Data collection}

Two sources of data were mainly used in this study: elevation and potential field (gravity and aeromagnetic) data. The elevation data are composed of high and medium resolution digital elevation models (DEMs). The high-precision DEM with a grid size $2 \mathrm{~m}$ (swissALTI3D) provided by the Swiss Federal Office of Topography (Swisstopo). The medium-precision ASTER Global DEM (GDEM) with a grid size $\sim 30 \mathrm{~m}$ is a product of METI (Japanese Minister of Economy, Trade and Industry) and NASA (United States National Aeronautics and Space Administration). Ground Bouguer and aeromagnetic maps are published at a scale of 1:500,000 by Swisstopo. The Bouguer data are part of an extensive gravimetric survey covered the whole Switzerland during the period 1975-1979. The survey was performed jointly by the Institute of Geophysics of the University of Lausanne (IGPL) and by the Swiss Federal Institute of Technology in Zurich. Almost $80 \%$ of the Molasse Basin was covered with a station density ranging between 1 and 3 stations per $1 \mathrm{~km}$ square (Klingelé, 1992). The theoretical gravity value was calculated using the International Gravity Formula of 1967. Topographic corrections were computed using a constant density of $2670 \mathrm{~kg} / \mathrm{m}^{3}$ to a depth of $167 \mathrm{~km}$ (Klingelé and Olivier, 1980). The aeromagnetic data are part of a wide aeromagnetic survey covering the Swiss territory between 1978 and 1981 by the Swiss Geophysical Commission. The data were performed at two different flight levels (5000 $\mathrm{m}$ and $1680 \mathrm{~m}$ above sea level) and along north-south oriented flight lines with a line spacing of $5000 \mathrm{~m}$. The higher flight level covered the whole Swiss territory, whereas the lower one covered the Molasse Basin and the Jura Mountains. The effect of diurnal variations, 
the effect of secular variations, instrument drift, and regional field were removed from the measured data before constructing the total intensity magnetic anomaly map (Klingelé, 1992; Klingelé and Verdun, 2003).

\subsection{Methods}

Geomorphic responses to tectonic forcing have been examined by combining analyses of drainage basins, and both, swath and longitudinal river profiles in areas of spatially variable topography. There are two key aspects for our examination: firstly, to compare drainage basins experiencing different levels of uplift/erosion rates and different lateral migration for their main stream trunks, and secondly, to identify any abrupt variations in the stream channel geometry and gradient along their courses. We employed three morphometric parameters to highlight the tectonic effects: (1) hypsometric integral to assess whether the variation in the landscape's topography is the result of the tectonic uplift, and/or other processes such as glacial erosion and contrasts in bedrock erodibility (Lifton and Chase, 1992; Pérez-Peña et al., 2009; Sternai et al., 2011; Stutenbecker et al., 2016; van Der Beek and Bourbon, 2007), (2) Transverse Topographic Symmetry index (TTSI) to quantify the possibility that lateral migration of main stream channels is induced by a tectonic tilting of the land surface (Cox, 1994; Cox et al., 2001; Garrote et al., 2006; Tsodoulos et al., 2008), and (3) channel's bottom elevation and gradient (SL index) to detect areas of abrupt changes in river gradients that could possibly indicate the presence of tectonic control (Delcaillau et al., 2011; Peters and van Balen, 2007; Seeber and Gornitz, 1983). The analysis was combined with geological field work and available geological and geophysical (gravity and aeromagnetic) data.

\subsubsection{Extraction of drainage systems}

The automatic derivation of drainage systems (both stream networks and basins) has recently attracted a considerable attention (e.g., Fairfield and Leymarie, 1991; McMaster, 2002; Palacios-Vélez and Cuevas-Renaud, 1986; Tarboton, 1997; Turcotte et al., 2000). Different algorithms have been developed to extract drainage systems from a DEM by using GIS tools. D8 is the most popular used algorithm for automatic drainage extraction (e.g., Anders et al., 2009; ArizaVillaverde et al., 2013, 2015; Liu and Zhang, 2011; Nigel and Rughooputh, 2010; Persendt and Gomez, 2015; Turcotte et al., 2000). This algorithm is specifically relied on determining direction of water flow from every cell in the DEM raster to one of its eight neighbors, either adjacent or diagonal, in the direction of the steepest descending slope (O'Callaghan and Mark, 1984; Tarboton, 1997). It has been implemented in ArcHydro Tools v 2.0, toolset for the water resource applications developed to operate within ArcGIS by the University of Texas (Maidment, 2002). These tools were used to extract drainage systems of the study area from a $2 \mathrm{~m}$-resolution DEM based on successive processing steps that are described elsewhere (ESRI, 2011).

\subsubsection{Drainage catchment analysis}

A total seventy-four drainage-catchments of mostly higher Strahler orders (Table A.1) were selected to quantify the causal influences of both tectonic uplift and tilt activities on the drainage basin morphology. The catchments were selected in areas characterized by significant measurements of bedding dip azimuths so that the possible tectonic tilt could be well defined.

3.2.2.1. Spatial distribution of hypsometric integrals. Recent studies have shown that hypsometric curves are very useful tools in geomorphic analysis, since they provide important indicators in regions experiencing intensive erosion processes (Chen et al., 2003; Hurtrez et al., 1999a, 1999b; Luo, 2000, 2002; Montgomery et al., 2001; Ohmori, 1993; Sternai et al., 2011; Willgoose and Hancock, 1998). The hypsometric curve describes the relative elevation distribution of a drainage basin and is thus a measure for the shape of a basin (Strahler,
1952).

Determining the hypsometric curve for a 3rd order basin is shown in Fig. S.1a (in the supplementary data), where (H) and (A) represent respectively the maximum height, and the total area of the basin and (x) represents the surface area within the basin above a given line of elevation (h). Strahler (1952) linked the shape of the hypsometric curve with three stages of landscape development, namely: youth, maturity and old age (Supplementary Fig. S.1b). These stages characterize weakly eroded regions with convex-up curves, moderately eroded regions with S-shaped curves, and significantly eroded regions with concave-up curves.

Pérez-Peña et al. (2008a) present an ArcGIS extension (CalHypso) to automatically extract hypsometric curves and calculate simple statistic attributes related to these curves (integral, skewness and kurtosis). The hypsometric integral is the area lying under the curve, ranging from 0 to 1 . The hypsometric integral value is very close to zero in the areas experienced the highest levels of erosion, whereas it is very close to 1 in weakly eroded areas (Keller and Pinter, 2002; Pike and Wilson, 1971; Strahler, 1952). The geomorphological significance of the hypsometric skewness and hypsometric kurtosis are shown by Harlin (1978), where a larger positive value of skewness reflects a greater amount of headward erosion in the upper reach of a basin; and a larger value of kurtosis reveals a more erosion in both upper and lower reaches of a basin. While hypsometry can assess erosion and describes the distribution of elevations within an area, it is possibly unclear whether there is a causal relationship between hypsometry and geological structures. This has led us to suggest the hypothesis that thrust-related fold growth creates a local relief, which is then eroded by rivers incision. We tested this hypothesis by detecting abnormally high values of hypsometric integral and relating them to existing structures, with taking into account the possible impact of other factors.

The hypsometry curves can be used in drainage watersheds of different sizes (e.g., Giaconia et al., 2012; Girish et al., 2016; Luo, 2000, 2002; Mahmood and Gloaguen, 2011; Omvir and Sarangi, 2008). Indeed the change in dimension of drainage catchments may play a more important influence on hypsometry than the uplift and erosion rates. Because small catchments are generally showing convex-up hypsometric curves associated with higher hypsometric integral values approaching 1.0, whereas larger catchments are having concave-up hypsometric curves with much smaller values approaching zero (Chen et al., 2003; Hurtrez et al., 1999a; Willgoose and Hancock, 1998). To avoid such pitfalls related to changes in catchments scale we calculated hypsometric curves not only for the drainage catchments but also for regular squares of different sizes through using CalHypso (Pérez-Peña et al., 2008a). Particular attention must also be paid here not only to the analysis size but also to the resolutions of the DEM used to calculate the hypsometric curves with their attributes. In this context, three different regularly spaced grids $(1 \mathrm{~km}, 2 \mathrm{~km}$, and $3 \mathrm{~km})$ with two different resolution DEMs $(2 \mathrm{~m}$ and $30 \mathrm{~m}$ ) were analysed. ArcGIS extension Hawth's Analysis Tools (Beyer, 2004) was first employed to create three vector grid files with $1 \times 1,2 \times 2$ and $3 \times 3$ square kilometres cells. The hypsometric curve and related attributes were then computed for each vector grid file over both DEMs separately. The hypsometric integral values obtained from each case were then interpolated in order to obtain a continuous surface. In this way, we obtained regularly-spaced grids of the hypsometric integral values for the whole area and quantify the degree of similarity between the results that obtained by using different scale sizes and DEM resolutions.

3.2.2.2. Drainage basin asymmetry. Tectonic tilting of the surface can cause a deflection of the stream channel away from the midline of drainage basin toward one of its sides (e.g., Keller and Pinter, 2002; Mathew et al., 2016). The Transverse Topographic Symmetry Index (TTSI) and Asymmetry Factor are commonly used to differentiate between symmetric and asymmetric drainage basins and to identify whether they had experienced by a possible tectonic tilting (Cox, 1994; 
Fig. 3. An example showing the calculation of Transverse Topographic Symmetry Index (TTSI). (a) High-resolution flow direction grid showing surface-water flow paths of 3rd order catchment no. 45. (b) Calculated TTSI via the method explained by Cox (1994). Two thick black transect-lines (1\&2) enable measurements of the distance between catchment midline to the trunk stream (Da) and from the catchment midline to the respective drainage margin (Dd). Here there are two vectors, each one composed of the magnitude ( $\mathrm{Da} / \mathrm{Dd}$ ) and the line azimuth. Polar plot (equal-area, lower hemisphere) visualizing the magnitudes and azimuths of TTSI vectors obtained from transect-lines. The polar plot has TTSI magnitude ranging from 0 in centre, meaning that the stream flowing near the catchment midline, to 1 on the outer margin, implying that the stream flowing near vicinity of catchment margin. Yellow star on the polar plot (a mean Fisher vector) represents the most prominent direction of stream migration. Rose diagram plotted in terms of frequency against TTSI azimuth values expressing preferential directions of channel migration. (c) Color-coded grid showing the spatial distribution of the TTSI magnitude values. Zone with a dark-green color (TTSI close to 0) indicating no lateral migration of the stream away from the catchment's midline whereas those with dark red (TTSI close to 1) highlighting a significant lateral migration of the stream toward the catchment's margin. (d) A critical issue about the accuracy of asymmetry factor (AF) that is not applied in this study. The calculated AF for the catchment no. 14 is very close to $50 \%$ (50.29\%), indicating there is no dominant direction of migration. Whereas the calculated TTSI shows two prominent directions of migration, NE and SW. (e) Schematic showing geomorphic response of drainage system to tectonic deformation caused by listric faults. When the earth's surface layers were tilted, the main stream was migrated away from the midline of basin toward the down-tilt direction. It is important to note here that other influencing factors, such as variation in rock-type erodibility can also generate similar geomorphic responses. (For interpretation of the references to color in this figure legend, the reader is referred to the web version of this article.)

Cox et al., 2001; Garrote et al., 2006; Keller and Pinter, 2002; Mahmood and Gloaguen, 2011; Sboras et al., 2010; Tsodoulos et al., 2008). The TTSI is described as a ratio (Da/Dd), where $\mathrm{Da}$ is the perpendicular distance between the trunk stream to the basin midline, and Dd is the perpendicular distance between the basin midline to the basin margin along the same line. The Asymmetry Factor is defined as the product of ratio (Ar/T) multiplied by 100 (Keller and Pinter, 2002), where Ar is the basin area on the right-side of the trunk stream while facing downstream, and $\mathrm{T}$ is the total area of the drainage basin. The - Asymmetry Factor and TTSI values are respectively close/equal to 50 and 0 if the river incises along the basin midline, and $\neq 50$ and $\approx 1$ if the river flows near to the basin boundary (Cox, 1994; Cox et al., 2001; Keller and Pinter, 2002). The absence of tectonic controls can often lead to develop symmetric basin with Asymmetry Factor $\approx 50$ and TTSI $\approx 0$, whereas the presence of such controls would develop asymmetric basin with Asymmetry Factor $\neq 50$ and $0<\mathrm{TTSI} \leq 1$ (Cox, 1994; El Hamdouni et al., 2007; Mahmood and Gloaguen, 2011). Asymmetric basin often occurs as a result of the tilt of the ground surface caused by uplifting folds and tilting fault blocks (Cox, 1994). Consequently, tilting of the ground surface generally causes the rivers to be laterally migrated toward the steepest gradient in a direction roughly parallel to its original course. Tectonic activity is not unique and other geological and geomorphological factors, such as paleo-slope surface, wedge-shaped channel (Levee) deposits, and coarse-grained alluvial deposits can also develop lateral channel migrations (Cox, 1994; Garrote et al., 2006).

In many orogenic belts like the Zagros and Himalaya, where there is a significant interaction between the growth of thrust-related folds and drainage system development, the rivers do not only flow in a direction roughly parallel to the strike of the fold axes, but also perpendicular to them (e.g., Burberry et al., 2010; Delcaillau et al., 2006; Ghassemi, 2005; Lu et al., 2017; Ramsey et al., 2008; Tucker and Slingerland, 1996; Walker et al., 2011). The rivers that flow parallel to the axis of the fold respond to changes in topographic gradient associated with anticlinal growth, by either incise a gorge through the nose of the folds, or by deflected out of their present courses around the tips of the growing folds in the direction of fold propagation (Burbank and Anderson, 2001; Ramsey et al., 2008). As the result, the rivers eventually flow perpendicular to the fold crests with a significant change in their direction along the length of the fold (Ramsey et al., 2008). Such rivers combine information about the lateral migration in the upper part of their courses, which is inherited from the initial stages of fold growth, with information about the perpendicular deflection, which is inherited when the rivers bend away from their initial courses in the direction of folds growth. Therefore, determining whether ground surfaces have experienced tectonic tilting is not always straightforward. Despite possible uncertainties, an attempt was made to confirm the hypothesis that tectonic deformation associated with the growth of thrust-related folds cause lateral tilting of the ground surface in a direction parallel to the direction of maximum compressive stress. Thus, evidence on a possible lateral tilting of the ground surface is the presence of channel migration that can be highlighted by TTSI. The TTSI was determined in successive steps using GIS tools and following the method described elsewhere (Cox, 1994; Cox et al., 2001). Due to the undulating and very irregular shapes of the drainage channel, the main stream trunk was divided into discrete segments of the same length ( $25 \mathrm{~m}$ in this case). The ArcGIS's Polygon to Centerline tool (Dilts, 2015) was used to extract a centerline for a given catchment vector layer. A series of transect-lines that were created orthogonally to the stream's segment-lines were divided into two groups; those bound by the stream and centerline (Da), and those bound by centerline and catchment boundary (Dd). The length of the groups Da and Dd, as well as their azimuth values were then calculated. Having the magnitude (the ratio of the length of Da to the length of Dd) and the azimuth values, we were able to graphically represent these data on the polar diagram. To determine the preferred direction of stream migration, the Fisher mean vector with its associated confidence cones were calculated using Stereonet v9.9.6 (Allmendinger et al., 2011; Cardozo and Allmendinger, 2013). To obtain further information about the spatial distribution of TTSI magnitudes, a color-coded grid bounding between catchment's midline and main-stream was created for each catchment. An example of calculating the TTSI for the 3rd order catchment (no. 45) that formed part of the Prealps area in the SE corner of the study area is shown in Fig. 3b and c. The calculated TTSI vectors (Fig. 3b and c) are significantly concentrated in the NW quadrant of the polar plot and have a mean vector (trend/magnitude) of $305.4^{\circ}$ / 0.20 with a small cone of confidence at the $95 \%$ level. The reliability of Asymmetry Factor is questionable, especially when there is an apparent deflection of the main river channel. This can be explained by the catchment no. 14 (Fig. 3d) where its main channel is sharply deflected in the northeast and southwest directions. The calculated Asymmetry Factor is almost close to the threshold $50(50.3 \%)$, indicating that there is no any significant migration direction for the principal channel, whereas the calculated TTSI indicates two main directions of migration with mean vector values (trend/magnitude) of $\mathrm{N} 39^{\circ} \mathrm{E} / 0.4$, and $\mathrm{N} 233^{\circ} \mathrm{E} / 0.49$. For this reason, the TTSI was only used in this study to infer any possible tectonic tilting.

\subsubsection{River longitudinal and topographic swath profiles}

To better define the location/source of the geomorphic anomalies, we suggest a new stepwise approach by integrating analysis of several longitudinal profiles along the course of three rivers (Broye, Glane, and Le-Veyron Fig. 1b). These rivers flow perpendicular to major sub/surface structural features over areas characterized by the presence of ubiquitous geological and geophysical (Bouguer gravity and aeromagnetic) data. The profiles have been evaluated based on two different aspects: channel floor gradient and geophysical properties. This integration is also supported by topographic-swath profiles and new geologic model based on stratigraphic and structural interpretation of seismic lines (Gruber, 2017; Meier, 2010). Our objective behind such a 
combination is to add important constraints on the origin of any possible geomorphic anomaly.

3.2.3.1. Channel floor-gradient. The spatial changes in the channel's bottom elevation and slope from its headwaters to its estuary are currently the most common indicators used to detect signs of Quaternary tectonic activity. Any rapid change in these properties causes pronounced geomorphic anomaly or knickpoint that represents non-steady state signatures in the river channel geometry. Such anomaly results from several factors, such as lithologic resistance to fluvial erosion, variations in tectonic uplift, changes in stream discharge, changes in local base-level, and rock-slope failures (Bishop et al., 2005; Brocard and van Der Beek, 2006; Clark et al., 2004; Delcaillau et al., 1998; Duvall et al., 2004; Gardner, 1983; Hack, 1973; Hayakawa and Oguchi, 2006; Korup, 2006; Larue, 2007; Norton et al., 2010a; Ouchi, 1985; Rabin et al., 2015; Radaideh et al., 2016; Schlunegger, 2002; Seeber and Gornitz, 1983; Stutenbecker et al., 2015, 2016; Whipple and Tucker, 1999). Thus, the shapes of the river longitudinal profiles reflect the causal relationship between lithology, fluvial erosion, tectonics, and base level change (Clark et al., 2004; Delcaillau et al., 1998; Hack, 1973; Kale et al., 2013; Merritts and Vincent, 1989; Wobus et al., 2006). The concave-up longitudinal profile indicates that erosion has kept pace with tectonic uplift and thus, the rates of uplift equal the rates of erosion. If the rate of fluvial incision is greater than the rates of rock uplift and base-level fall, then the shapes of the profile tend to show a smooth downstream concavity due to increase of sediment flux. Conversely, if the rate of uplift is greater than fluvial incision, then the shapes of the profile will be convex (Seeber and Gornitz, 1983).

Several geomorphic indices have been proposed to detect the knickpoint locations along the river courses. Among them, the most commonly used indices are river channel steepness and river channel length-gradient. The channel steepness index is a measure of streamchannel slope normalized to drainage area (Wobus et al., 2006), and follows the equation: $S=k_{s n}{ }^{*} A^{-\theta r e f}$, where $S$ is the channel slope, $k_{s n}$ is a normalized steepness index, $\mathrm{A}$ is the upstream drainage area, $\theta_{\text {ref }}$ is a reference concavity index. It has widely used to infer relative differences in rock uplift in a variety of landscapes (Chittenden et al., 2013; Cyr et al., 2010; Fraefel, 2008; Gasparini and Whipple, 2014; Kirby et al., 2003; Kirby and Whipple, 2012; Norton et al., 2010a; Ouimet et al., 2009; Safran et al., 2005; Schlunegger et al., 2011; Snyder et al., 2000; Whipple and Gasparini, 2014).

The channel length-gradient index (also known as SL index) is the product of the channel slope and channel length (Hack, 1973), and is represented as: $\mathrm{SL}=(\Delta \mathrm{H} / \Delta \mathrm{L})^{*} \mathrm{~L}$, where $\Delta \mathrm{H}$ is the difference in elevation between the ends of the segment, $\Delta \mathrm{L}$ is the length of the segment, and $\mathrm{L}$ is the total length from the midpoint of the channel segment to the drainage divide (Supplementary Fig. S.2). The SL index has been widely adopted in different geodynamic settings (Chen et al., 2003; Delcaillau et al., 2011; El Hamdouni et al., 2007; Figueiredo et al., 2018; Font et al., 2010; Gao et al., 2016; García-Tortosa et al., 2007; McKeown et al., 1988; Merritts and Vincent, 1989; Troiani et al., 2014) because (i) it is highly sensitive to changes in channel slope that mainly related to the presence of tectonic and/or lithological controls on the basin configuration (Chen et al., 2003; Hack, 1973; Pedrera et al., 2009; Pérez-Peña et al., 2008b; Troiani and Seta, 2008); and (ii) the SL values can be statistically filtered to remove those values that mainly characterize each lithology unit from the whole dataset (Troiani et al., 2014; Troiani et al., 2017). In light of the above-mentioned advantages, several longitudinal profiles based on the SL index were constructed to identify any significant anomaly in the study area. The SL index was calculated at equally spaced stream segments of $25 \mathrm{~m}$ using $2 \mathrm{~m}$ DEM.

3.2.3.2. Geophysical and geological observations. Gravity and aeromagnetic data can be helpful in areas where rock outcrops are typically scarce or absent. Analysis of those data can provide important information about the subsurface structure of the geologic bodies exist beneath the respective river. Surface and blind faults may have distinct gravity and magnetic signatures, especially when they are accompanied by the occurrence of mineral deposits and abrupt changes in the density of rocks. Such signatures, which are often subtle and sometimes hard to distinguish from other causes of apparent anomalies, can be highly improved and recognized by applying selective enhancement filters, such as horizontal gradient, total gradient, vertical integral and derivative (Bournas and Bake, 2001; Boyce and Morris, 2002; Cooper and Cowan, 2007; Elo et al., 1989; Ferraccioli et al., 2001; Grauch and Drenth, 2009; Mickus and Hinojosa, 2001; Phillips, 2000).

We used both Bouguer and residual aeromagnetic maps to define possible subsurface anomalies that may coincide in the space with the observed geomorphic anomalies along the river path. We isolated the regional trends from Bouguer map to obtain residual anomalies, which correspond to the shallow structural boundaries (Guy et al., 2014). The regional trends, which originate from deep-seated sources, were calculated by applying second order polynomial fitting method (e.g., Li and Oldenburg, 1998; Thompson, 1967; Zeng, 1989) using Golden Software's Surfer 8.0 (Golden, 2002). The residual Bouguer and aeromagnetic maps were then processed and filtered using Geosoft eXecutables (Phillips, 2007). We extracted profiles from the resulting enhanced grids along the locations of river channels. In this way, a database of each river showing the values of latitude, longitude, distance, elevation, mean slope, gravity with its filters, and aeromagnetic with its filter was built. These data were finally imported into Golden Software's Grapher (Golden, 2002) and used to create river longitudinal profiles. Moreover, we extracted 2D geological cross-sections along the path of the rivers from a new 3D geological subsurface model (Gruber, 2017) in order to define any possible blind faults that could be responsible for the occurrence of the geomorphic anomalies.

3.2.3.3. Topographic swath profile. Swath profiles describe statistical properties (minimum, mean, maximum, etc.) of elevation values lying within a given domain. The shape of these profiles may provide clues about the process patterns or any other transient features that have contributed to shape the region (Brocklehurst and Whipple, 2007). A convex-up shaped minimum elevation curve is typical of regions that experienced glacial erosion (e.g., Dortch et al., 2011). In many landscapes, a mean elevation curve lies close to the minimum curve. An upward deflection of the mean occurs when the mean approaches the maximum elevation. This deflection indicates that the rates of hillslope lowering are unable to keep pace with the rate of rock uplift (Burbank and Anderson, 2011).

The analysis of the swath profile is often based on rectangular window, whereas here we used irregular-shaped polygon around the whole path of river so that local-scale variations in topographic relief can be recognized anywhere on the both sides of river. Our objective is to detect how geomorphic anomalies along the river course can be robustly linked to local-scale differences in topography. The swath area was outlined by creating a buffer polygon or corridor with a distance of $500 \mathrm{~m}$ on either side of the targeted river channels ( $1 \mathrm{~km}$ wide). Then a set of transects evenly spaced at an interval of $20 \mathrm{~m}$ was created perpendicular to the long axis of the buffer polygon. Maximum, minimum, mean, and standard deviation values of the altitude were extracted for each individual transect-line from a $2 \mathrm{~m}$-DEM dataset, using ArcGIS's spatial analyst toolset. The local relief can, however, be defined along these profiles as the difference between maximum and minimum elevation at each point (Kühni and Pfiffner, 2001).

\subsubsection{Lithological filter}

The SL and hypsometric indices are particularly sensitive to variation in lithology and rock-type erodibility (Hack, 1973; Hurtrez and Lucazeau, 1999; Lifton and Chase, 1992). This influence can be clearly observed in areas where there is a specific lithological unit that is more resistant to erosion than adjacent units. Fluvial erosion of such 
lithological heterogeneities can generally result in the formation of ridges that will inevitably appear as knickpoints in the longitudinal profile. It can also cause more variability in the shape of the hypsometric curve, and thus hypsometric integral value, than the tectonic process itself. Massive, resistant rocks (i.e., carbonate rocks) of an erosional escarpment have a convex-up hypsometric curve with high hypsometric integral value, whereas weak rocks (i.e., weak sands and clays) of low relief have a concave-up hypsometric curve with low hypsometric integral value (Hurtrez and Lucazeau, 1999; Strahler, 1952). To get rid of lithology signals, we applied a special filter that is defined by Troiani et al. (2014). The filter relies on statistical methods to remove those SL and hypsometric integral values that are dominant in each lithology cropping out in the study area from the entire dataset. More specifically, we classified the lithology information, which is provided by Swisstopo at scales of 1:25,000 and 1:500,000, into four classes (limestone/dolomite rocks with marl, silt/clay deposits, calcareous sandstone with marl, and hard sandstone/conglomerates) according to the similarity of composition and hardness levels. We then created a histogram with standard box plots to visualize the frequency distribution of hypsometric integral and SL values within each group of lithologies, and highlight the statistical anomalies. Only these latter were presented in the final map using the Ordinary Kriging method (e.g., Troiani et al., 2014) and were further assessed using additional geological information. However, the statistical examination of lithology effect on the hypsometric integral for a drainage basin is not always possible, especially in the case where the basin is made up of many different lithological units. For this reason we tested the impact of lithology on the hypsometric integral values that are derived from a regularly spaced grid, rather than from a basin.

\section{Analysis and results}

Here we present the results obtained from the combined analysis of drainage basins and several topographic-swath, and longitudinal river profiles.

\subsection{Hypsometric curves and attributes}

The hypsometric analysis for the selected fluvial catchments of the western part of the Switzerland shows a variety of hypsometric curve patterns and wide range values of hypsometric attributes (Table A.1 in the supplementary information). To highlight these differences, the values of the hypsometric integral are plotted against the hypsometric kurtosis and skewness values (Fig. 4). Many catchments have very similar hypsometric attribute values, which make them cluster together more tightly than others (Fig. 4). Both variables (hypsometric integral vs. hypsometric skewness and hypsometric integral vs. hypsometric kurtosis) follow the same distribution (Fig. 4). On the basis of relationships among the values of hypsometric integral, skewness and kurtosis (Fig. 4), twenty-one different shapes of the hypsometric curves were distinguished (Fig. 5a). As can be seen from the graph in Fig. 4, the values of hypsometric skewness and hypsometric kurtosis provided further information about the curve patterns, especially in the cases of identical values of hypsometric integral. For example, styles 13a \& 13b (Fig. 4) have apparently very similar hypsometric integral values but both hypsometric skewness and hypsometric kurtosis values for style $13 \mathrm{~b}$ are slightly increased. This is confirmed by the change in shape of curves from being nearly S-shape (style 13a, Fig. 5a) to concave upward (style 13b, Fig. 5a). The same observation can be made for the styles (12, 12a and 12b, Fig. 4), and for the styles (16a \& 16b, Fig. 4). Ignoring hypsometric kurtosis and hypsometric skewness could thus have adverse effects on the ability to recognize different patterns of hypsometric curves. Fig. 5b shows the spatial distribution of hypsometric integral within the study area. Significant numbers of catchments have hypsometric integral $>0.52$ and are mostly characterized by convex hypsometric curves, which indicate that an important volume of original rock mass has not yet eroded within these catchments (Strahler, 1952).

On the other hand, we find a considerable consistency among the results of the hypsometric analysis obtained when the same/different DEMs and grid size were used (Fig. S.3 in the supplementary data). Thus, it can generally be suggestive of no significant influence of the changing in DEM resolution and in the size of analysis area on the calculation of hypsometric attributes within the study area. Conversely, the accuracy of other morphometric results (e.g., SL index) is sensitive to the resolutions of the DEMs.

\subsection{Drainage basin asymmetry (TTSI)}

The results of Transverse Topography Symmetry Index (TTSI) that has been applied to 71 of the total 74 catchments are shown in the supplementary information (Table A.1, Figs. S.4 and S.5 in the supplementary data). However, it was difficult to determine the TTSI for the catchments no. 58, 60, and 61 because there is no clear mainstream, but several drainage tributaries flow into the basin outlet. Overall, TTSI values range from 0.014 (for both symmetric catchments no. 32 and 42) to 0.885 (for highly asymmetric catchment no. 5, Table A.1). For comparative purposes, to obtain further information and a more interpretable visualisation, we divided the TTSI results into two large groups according to their spatial distribution: those obtained from catchments located around and along the Swiss part of Pontarlier fault (Fig. 6) and those obtained from catchments of the central and easternmost part of the study area (Fig. 7).

TTSI values of the catchments $3,8,53,62$ and 65 of the domain-I (set-0, Fig. 6a) and the catchments 21, 37, 43, and 46 of the domain-II (set-0 in Fig. 7a) show very low dispersion (TTSI equal or very close to 0 ) and without uniform migration trends, whereas most other catchments in both domains display clearly visible migration trends with medium to high scale of dispersion. TTSI for some catchments (no. 1, 5, 14, and 72) display evidence of multi-directions of lateral migration for their principal channels, indicated by differently oriented mean vectors in the polar plots (set-6, Fig. 6a) and (sets-7, -8, -9, Fig. 7a).

Three main directions of lateral channel migrations in domain-I can be distinguished, as shown in the corresponding polar plots (Fig. 6a). Eight catchments (7, 27, 51, 52, 54, 55, 56, and 57, set-1 of Fig. 6a) are characterized by medium-scale lateral movement for their principal drainage channels toward SE direction, and have Fisher mean vectors (trends/magnitudes) of $129^{\circ} / 0.54,151^{\circ} / 0.67,154^{\circ} / 0.18,146.9^{\circ} / 0.33$, $153^{\circ} / 0.35,123^{\circ} / 0.42,133^{\circ} / 0.36$, and $144^{\circ} / 0.71$, with relatively small to medium cones of confidence at the $95 \%$ and $99 \%$ levels (Supplementary Table A.1). SW direction of lateral channel migration (set-2, Fig. 6a) was found in seven catchments with mean TTSI magnitudes ranging from 0.246 (catchment no. 59) to 0.572 (catchment no. 50, Table A.1). The third set in the domain-I is characterized by NW lateral migration (set-3, Fig. 6a). In addition to the aforementioned main trends, there are two other minor trends of channel migration, NE and $\sim$ E (sets-4 and -5, Fig. 6a). Both NW and NE lateral migration are observed together in the catchment no. 1 (set-6, Fig. 6a). Such a combination of different migration trends in the same drainage channel most probably indicates that the relevant catchment has experienced a tectonic movement with two different directions.

Domain-II (43 out of 74 catchments) shows four dominant sets of lateral channel migration (Fig. 7a). The migrations of principal drainage channels toward SE direction are also dominant in this domain (Fig. 7a). It is observed alone in twelve catchments (set-1, Fig. 7a) and in combination with other migration directions in the catchments 5 and 72 (set-9 and -8, Fig. 7a). NW directed lateral channel migration was found alone in seven catchments (set-2, Fig. 7a) and in a combination with SE migration in the catchment 72 (set-8, Fig. 7a). Westward migration, which is not noted in domain-I, is observed in seven catchments (set-3, Fig. 7a). Eastward migration, which is more common in this domain than in the domain-I, is observed in four catchments (set-4, 


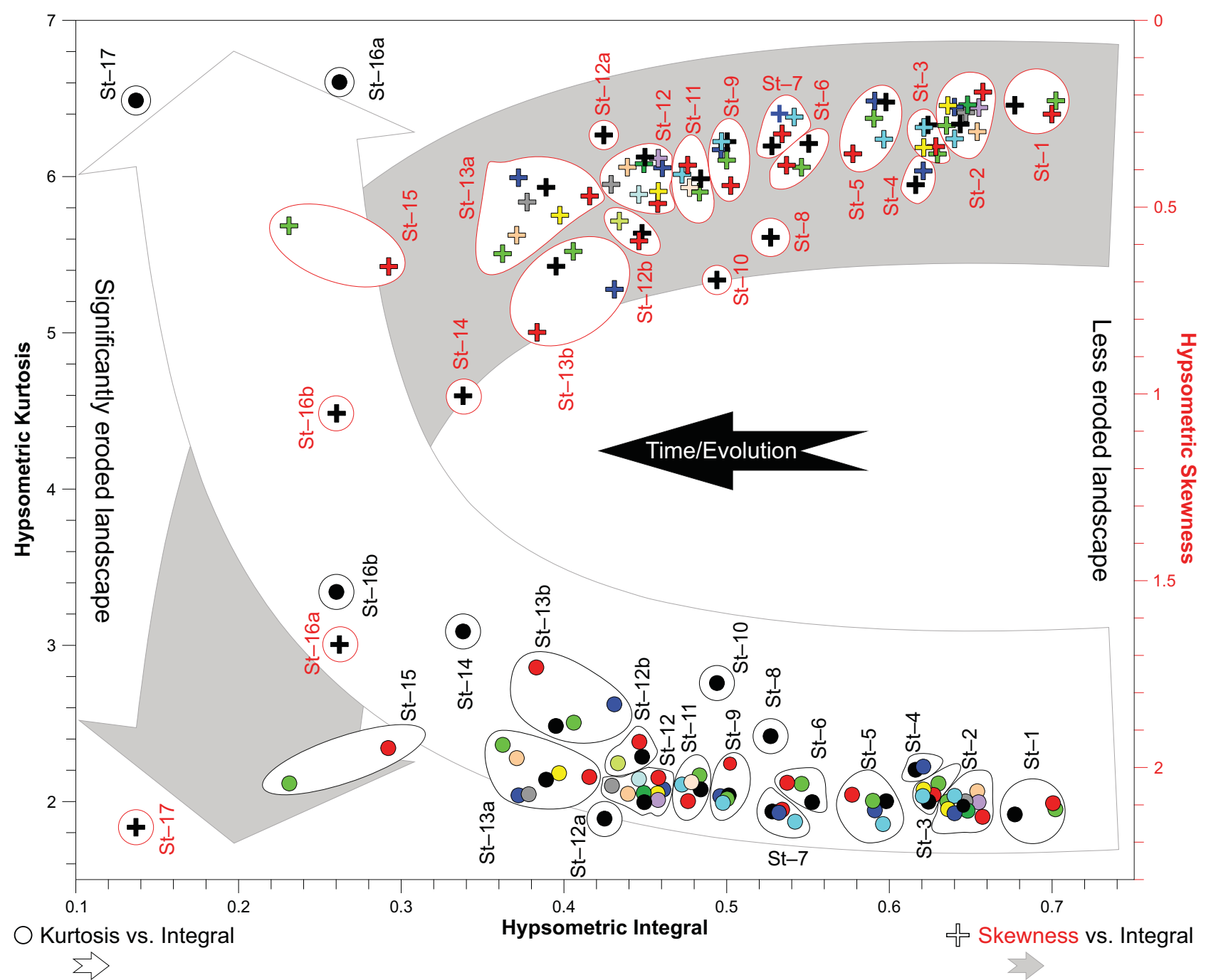

Fig. 4. A graph showing hypsometric integral as a function of the hypsometric kurtosis and skewness values. In general, the hypsometric integral decrease when the skewness and kurtosis values becomes larger. Based on this graph, twenty-one different styles of hypsometric curves can be distinguished. Each style is indicated by a symbol "St" with a number on the graph. In each style, dot and cross symbols with the same color accurately represents one drainage catchment. Colored dots represent hypsometric integral versus hypsometric kurtosis values while colored crossmark represents hypsometric integral versus hypsometric skewness values. (For interpretation of the references to color in this figure legend, the reader is referred to the web version of this article.)

Fig. 7a). In addition to the aforementioned main trends, there are three other minor trends of channel migration observed only in few catchments. NE migration is only observed alone in three catchments (set-5, Fig. 7a) and in combination with SW direction of migration in catchment no. 14 (set-7, Fig. 7a). Unlike domain-I, SW- migration is less common and only observed alone in two catchments (set-7, Fig. 7a), and in combination with SE direction of migration in catchment 5 (set9, Fig. 7a). South directed lateral channel migration (set-6, Fig. 7a), which is not also noted in domain-I, is observed only in two catchments (36, and 74).

\subsection{Topographical, geophysical and longitudinal profiles}

The investigated parts of the Broye, Glane, and Veyron rivers vary in length from $20.6 \mathrm{~km}$ to $44.5 \mathrm{~km}$, and in the altitude difference (between upstream and downstream) from $885.9 \mathrm{~m}$ (Glane river) to $444.3 \mathrm{~m}$ (Broye river). Their topographical, longitudinal, and geophysical profiles show variable gradients and anomalies along their entire courses. Here it is important to bear in mind that small-scale spatial variation in the channel gradients, and topographical and geophysical characteristics was not taken into account because it could result from the inaccuracy or unavailability of the data.

The studied part of the Broye river extends $44.5 \mathrm{~km}$ from the south, near Palézieux-village in the Swiss Prealps, to the northeast in the vicinity of the city of Payerne, and crosses many major fault systems (Fig. 8). A swath profile shows significantly higher values in the mean and maximum altitudes on the upstream side (southern side) of the river (Fig. 8a). Although the mean and maximum altitude curves show roughly the same rate of change (increase or decrease) along the entire strip, five distinct positive topographic anomalies can be recognized (labelled B0-B4, Fig. 8a). Fluvial incision variations in a given swath can be indicated by the standard deviation (e.g., Riquelme et al., 2002), which is the most robust measure of these variations (Evans, 1998). Thus the highest rate of fluvial incision is observed between profile distances of $\sim 12$ to $\sim 25 \mathrm{~km}$ (Fig. $8 \mathrm{a}$ ).

The analysis of longitudinal profile shows three main SL anomalies (B0, B1and B2 in Fig. 8b), which show a direct correlation with the location of the topographic anomalies (B0, B1and B2 in Fig. 8a). The highest value of SL $(\sim 1300 \mathrm{~m})$ is observed at profile distance $\sim 11.5 \mathrm{~km}$ (Fig. 8a). From the middle toward the end of the profile (distance $>$ $21 \mathrm{~km}$, Fig. 8b), the river was channelized and regulated which was not considered here in terms of the SL assessment. 


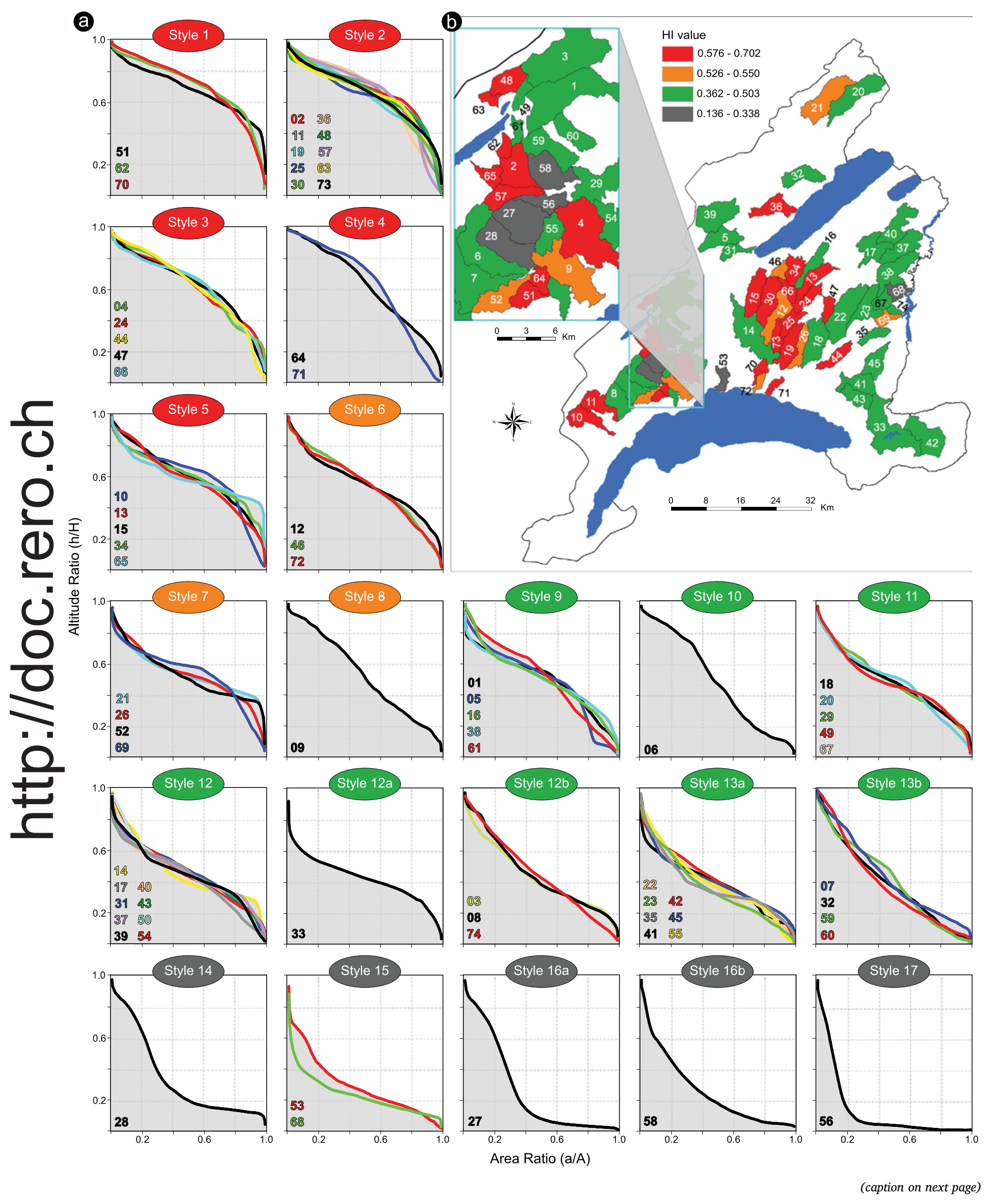


Fig. 5. Hypsometric curves for seventy-four catchments located in the westernmost part of Switzerland. (a) Twenty-one different shapes of hypsometric curves discriminated based on the relationships between the values of hypsometric integral, skewness and kurtosis (Fig. 4). The area under these curves portrays the volume of material left after erosion (Strahler, 1952). The shapes of these curves are diversified, mostly convex up, S-shaped, and extremely concave up. Catchment no. 62 of the style 1 has the highest value of the hypsometric integral relative to the rest of the data set with a convex-up curve, reflecting a significant amount of land material still existed at high altitude. Whereas catchment no. 56 of the style 17 has the lowest values of the hypsometric integral with the most concave-up curve, indicating that a significant amount of catchment's materials has been removed. (b) Catchment-scale distribution of the hypsometric integral in the westernmost part of Switzerland. The numbers identify each catchment.

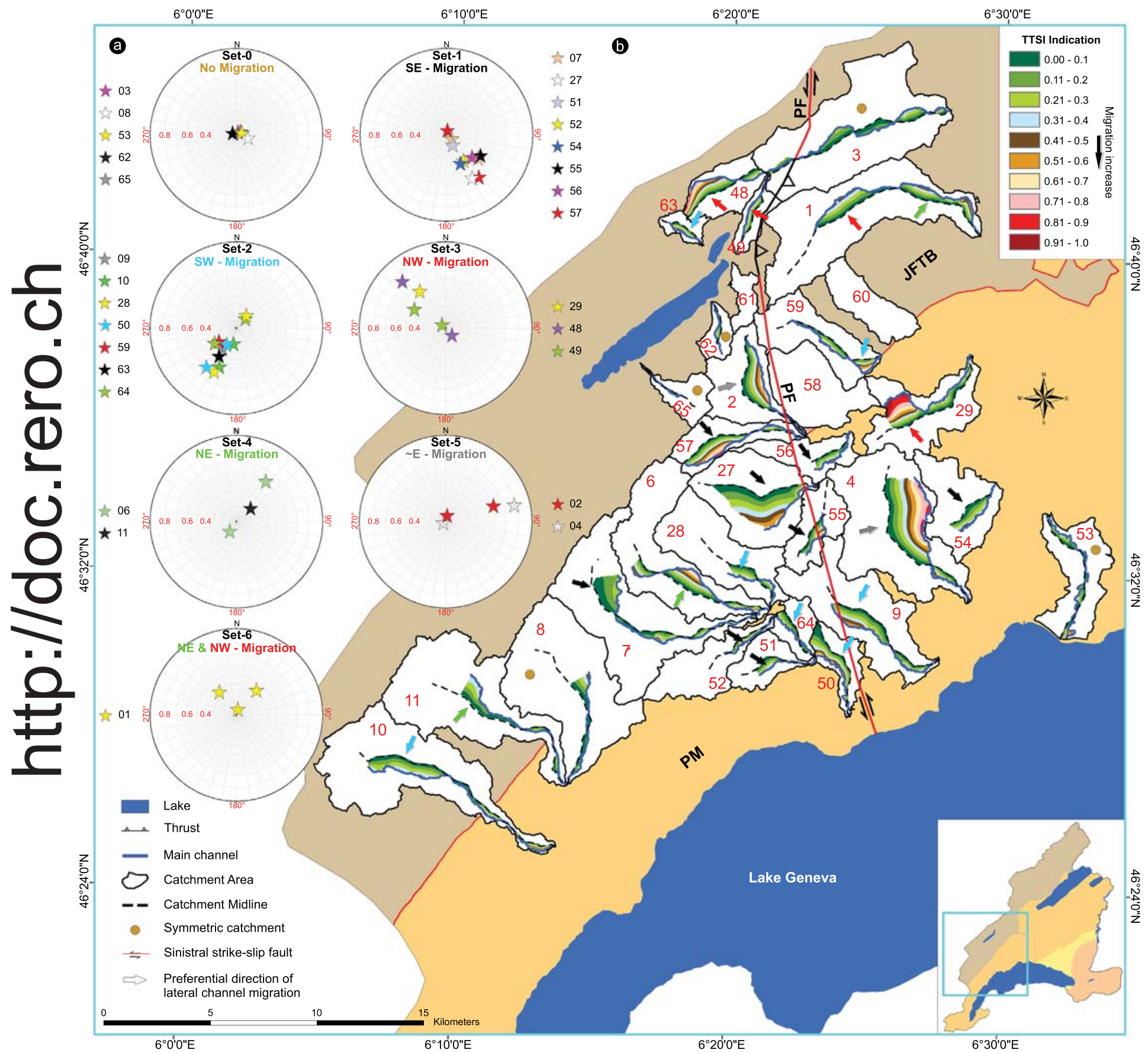

Fig. 6. Mean vectors of TTSI (Transverse Topography Symmetry Index) for the drainage catchments of the westernmost part of the Switzerland (Domain-I). (a) Polar plots (equal-area, lower hemisphere) showing the preferred direction of the principal channel migration in each catchment. Set-0 (TTSI magnitudes $\approx 0$ ) indicates there is no preferred direction of the principal channel migration (symmetric catchments). The principal channels of the most catchments have migrated uniformly toward SE and SW directions, set- 1 and set- 2 respectively. Keys for polar plot are the same as those in Fig. S.4b. (b) Map showing color coded distribution of TTSI magnitude values. Anomalous zone with dark red color (TTSI magnitude $\approx 1$ ) implying that stream flowing nearby the catchment margin, whereas those of dark green (TTSI magnitude $\approx 0$ ) indicating that stream flowing nearby the catchment midline. TTSI analysis are not applied to the catchments no. 58,60 and 61 because they have no clear principal channels, but rather several drainage tributaries flowing into their outlets. PF: Pontarlier Fault; JFTB: Jura fold-thrust belt; PM: Plateau Molasse. (For interpretation of the references to color in this figure legend, the reader is referred to the web version of this article.) 


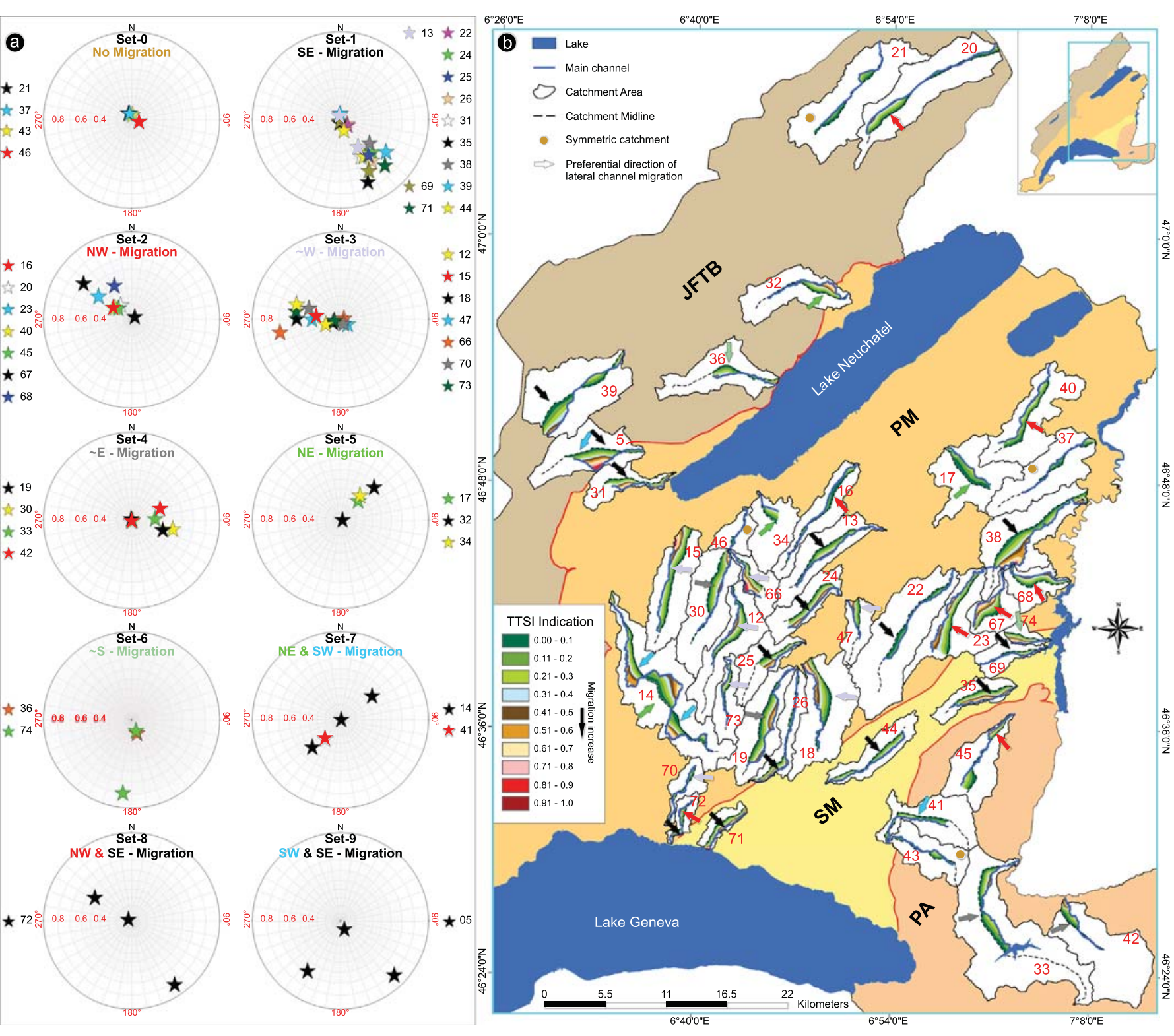

Fig. 7. Mean vectors of TTSI (Transverse Topography Symmetry Index) for the drainage catchments of the westernmost part of the Switzerland (Domain-II). (a) Polar plots (equalarea, lower hemisphere) showing the preferred direction of the principal channel migration in each catchment. Set-0 (TTSI magnitudes $\approx 0$ ) indicates there is no preferred direction of the principal channel migration (symmetric catchments). Most of the catchments showing a significant migration for their principal channels toward SE and NW directions (set-1 and set- 2, respectively). Keys for polar plot are the same as those in Fig. S.4b. (b) Map showing color-coded distribution of TTSI magnitude values. Anomalous zone with dark red color (TTSI magnitude $\approx 1$ ) implying that stream flowing nearby the catchment margin, whereas those of dark green (TTSI magnitude $\approx 0$ ) indicating that stream flowing nearby the catchment midline. JFTB: Jura fold-thrust belt; PA: Prealps; PM: Plateau Molasse; SM: Subalpine Molasse. (For interpretation of the references to color in this figure legend, the reader is referred to the web version of this article.)

A distinct change in the curves of the gravity filters and horizontal gradients of magnetic data at profile distances between $\sim 5$ to $\sim 20 \mathrm{~km}$ (Fig. 8c and d) occurs in approximately the same positions of the aforementioned anomalies, B1 and B2 (Fig. 8a and b). Pre-Cenozoic rocks beneath this river, which are relatively deformed and dip down to the south, occur at a significant depth (Fig. 8e) and are buried beneath the thick Cenozoic sedimentary rocks (Gruber, 2017). In general, toward the south in upstream direction (a distance $<20 \mathrm{~km}$ ), there is a clear increase in the Cenozoic thickness (Fig. 8e) as well as in the residual magnetic gradients (black curve, Fig. 8d).

The Glane river extends about $37 \mathrm{~km}$ from its confluent (Neirigue stream) in the southeast, near the town of Vuisternens-devant-Romont, to its outlet into the Sarine river (Supplementary Fig. S.6). The swath topographic profile (Supplementary Fig. S.6a) shows that the maximum and average altitude curves are changing at nearly the same rate, and reveals several pronounced positive relief zones (labelled by G0, G1, G2, G3, and G4, Fig. S.6a). The highest values of standard deviation (highest rates of incision) are observed in three zones namely, G1, G3, and G4, where the differences between maximum and minimum altitudes are highest. The highest SL gradients are noted at two zones (G3 and G4, Fig. S.6b). Small, but noticeable, changes in the first vertical gradients of the Bouguer gravity at a profile distance $<12 \mathrm{~km}$ (Fig. S.6c) are noted in the same place of the previously determined anomalies, namely G0 and G1 zones (Figs. S.6a and S.6b). Relatively high residual Bouguer values were observed between profile distances 27-34 km (G3, Fig. S.6c), where the residual magnetic gradients are gradually increasing (Fig. S.6d) and the thickness of Cenozoic rock is relatively decreasing (Fig. S.6e). A dramatic decrease in residual magnetic values (Fig. S.6d) is observed at profile distance $<6 \mathrm{~km}$, and coincides with a decrease in the altitude of the bottom of the river channel 

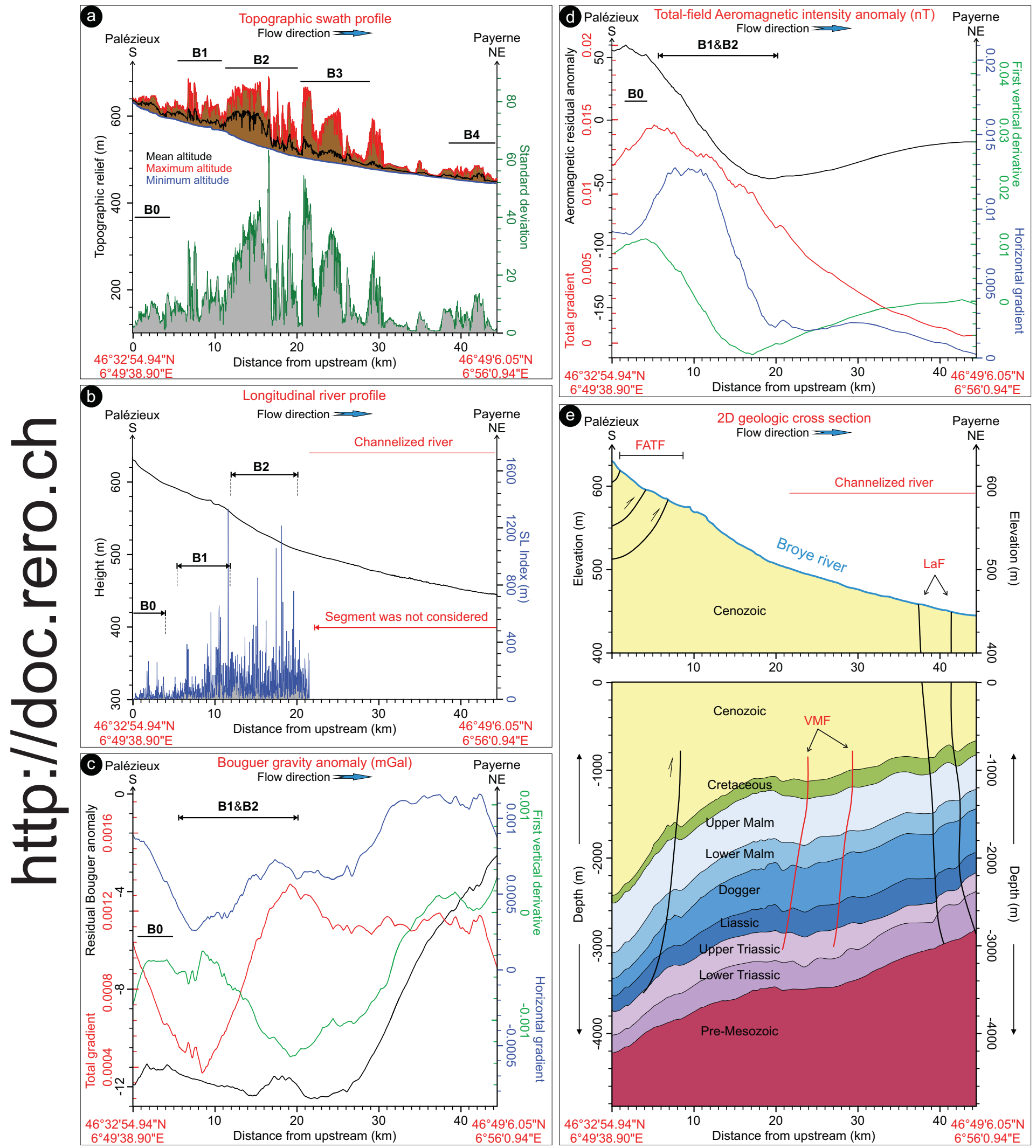

Fig. 8. Topographical, geophysical, and longitudinal profiles of the entire 44.5-km length of the Broye river in the westernmost of Switzerland. (a) One-km wide swath profile showing a conspicuous relief approximately on the middle part of river (zones B2 and B3). Maximum and mean altitude curves nearly follow the same pattern of change. (b) Longitudinal profile based on the channel's bottom elevation and gradient (SL index). SL index clearly displays three prominent breaks, labelled by B0, B1, and B2. (c) and (d) Unfiltered and filtered residual gravity and aeromagnetic anomaly profiles along the river path, respectively. (e) Geological crosssection along the river, extracted from a 3D geological model based on the interpretation of seismic reflection data (Gruber, 2017), showing a significant decrease in the thickness of Cenozoic rocks from being $\sim 3000 \mathrm{~m}$ at the upper section of river to $<1200 \mathrm{~m}$ near the river mouth. Black and red colored lines represent different types of faults interpreted by Gruber (2017) and Meier (2010), respectively. FATF: Frontal Alpine thrust fault; LaF: La-Lance strike-slip fault; VMF: VuacherensMoudon fault. (For interpretation of the references to color in this figure legend, the reader is referred to the web version of this article.) 
(Fig. S.6e). The geologic cross section along the river consists of $\sim 2000$ to $\sim 2800 \mathrm{~m}$ thick Cenozoic sediments covering layers of Mesozoic age (Supplementary Fig. S.6e). Alternate patterns of high and low residual Bouguer values characterize the profile along the river (Fig. S.6c) and are relatively parallel to the subsurface geometry of the Mesozoic strata (Fig. S.6e).

The studied part of the Veyron river extends $20.56 \mathrm{~km}$ from its confluent (Malagne stream) in the west, near the town of Montricher, to the northeast in the vicinity of the town of la Sarraz (Supplementary Fig. S.7). Its swath profile shows three distinct topographic anomalies, located in the upper, central and lower parts of the profile (V0, V1 and V2, Fig. S.7a). The lower part of the profile, however, shows the highest rate of incision, as the standard deviation reaches 20 (Fig. S.7a). Two pronounced SL anomaly zones can be identified in the central and lower parts of the river course (V1 and V2, Fig. S.7b). The most prominent one (V2 Fig. S.7b) is characterized by a sharp break in the elevation curve with the highest SL value $(\sim 3000 \mathrm{~m})$. A conspicuous change in the filter curves of the gravity and magnetic at the central part of the profile $(\sim 6$ $-\sim 14 \mathrm{~km}$, Figs. S.7c and S.7d) is noted at the same location of the zone V1 (Figs. S.7a and S.7b). Cretaceous rocks under the studied part of the river course, occur at shallow depth and crop out in a small portion at the upper and lower section of the river course (Fig. S.7e).

\section{Discussion}

We discuss the results of GIS-based quantitative geomorphic analysis and the level of evidence they provide to highlight the effects of tectonic deformation on the development of fluvial landscape in the westernmost part of Switzerland.

\subsection{Tectonic controls on hypsometry}

The results achieved by considering interrelationships among hypsometric attributes (integral, skewness and kurtosis), presented as graph (Fig. 4), clearly highlight the importance of the hypsometric attributes for classification and characterization of landscape evolution patterns. According to these attributes, significant differences in the shape of the hypsometric curves, and thus fluvial landscapes, were observed (Fig. 5a), that cannot be fully noticed with the integral values alone. These variations reflect a relatively high level of evolutionary diversity in the study area that is usually attributed to the isolated or combined impacts of tectonic uplift, lithology, and glacial erosion (e.g., Hurtrez and Lucazeau, 1999; Lifton and Chase, 1992; Schlunegger and Norton, 2013; Sternai et al., 2011; Stutenbecker et al., 2016).

Knowledge about the effects of the lithology and glacial erosion is therefore essential for evaluating tectonic role. The lithology effect was statistically segregated (Fig. 9) using a special filter, described in Section 3.2.4. According to the composition of the host lithology, the hypsometric integral values were classified into four different groups. Summary statistics for each group are separately shown in Fig. 9a. Although there are some anomalous observations, the hypsometric integral values in all the classes are roughly clustered around their mean values of $\sim 0.5$ and follow quite closely a normal distribution, indicating that the lithology exerted an important influence on the distribution of hypsometric integral values. The anomalous observations, which have unusually high and low hypsometric integral values, are sparse and irregularly distributed in the study area (labelled H-1, H-2, $\mathrm{H}-3$, and L in Fig. 9b). These abnormalities can't be explained as being the results of variation in lithology, but rather as the results of glacial erosion or tectonic processes. The Alpine glacier at the last glacial maximum had significantly influenced the landscape evolution of the Swiss Alps and the northern Alpine foreland (e.g., Norton et al., 2010a; Salcher et al., 2014; Schlunegger and Norton, 2013; Stutenbecker et al., 2016; Valla et al., 2011; van Der Beek and Bourbon, 2007). It left behind unique topographical imprints, which are noticeably different from those achieved by fluvial erosion process, such as hanging valleys, moraine ridges, glacial cirques, and glacially polished rocks (e.g., Fiebig and Preusser, 2008; Ivy-Ochs et al., 2006; Kelly et al., 2004; Wirsig et al., 2016). Several studies have shown that the last glacial maximum deglaciation associated with an isostatic crustal rebound of the Alpine region (Gudmundsson, 1994; Mey et al., 2016). This implies that the isostatic rebound cannot be ruled out as partly or largely responsible for the elevation differences in the study area. However, it is not possible here to differentiate between the impacts of post-glacial isostatic adjustment and tectonic processes.

The extent of the Alpine glacier at the last glacial maximum in the Swiss Alps and in the northern Alpine foreland (around 24,000 years ago) was reconstructed by a group of researchers (e.g., Florineth, 1998; Florineth and Schlüchter, 1998; Kelly et al., 2004), which was then updated in a recent map covering the entire Switzerland by (Bini et al., 2009). This map (Fig. 9c) displays almost none or very limited influence of ice on the areas where the unusually high values of hypsometric integral ( $\mathrm{H}-1$ and $\mathrm{H}-3)$ are developed, and therefore the latter can be directly attributed to tectonic activity. In this context, we interpreted anomaly H-1 (Fig. 9b) as a result from the growth of the anticlines in response to slip movements along thrust faults. This agrees with our hypothesis that thrust-related fold growth creates a local relief, which is then eroded by rivers incision. The H-3 anomaly (Fig. 9b) occurs on the hanging wall of the Frontal Alpine thrust fault system, suggesting that the tectonic movement along Frontal Alpine thrust fault system is most probably responsible for increasing the hypsometric integral values.

Conversely, high values of hypsometric integral (H-2) occur in the area that was covered by a $\sim 1 \mathrm{~km}$ thick ice sheet (Fig. $9 \mathrm{~b}$ and $\mathrm{c}$ ), where glacial erosional features were identified using the Swisstopo LiDAR data. Thick glaciers that have high ice discharges often induce a significant landscape modification through increasing the amount and intensity of glacial erosion and consequently a reduction in the value of hypsometry (Brocklehurst and Whipple, 2004). This suggests that the anomaly H-2 is not caused by the glacial erosion but by tectonic effects. Comparison of the location of anomaly $\mathrm{H}-2$ with subsurface tectonic map suggests (Fig. 9b) that it is caused by reactivation of pre-existing thrust fault. The unusually low values of the hypsometric integral ( $\mathrm{L}$ in Fig. 9b), which are roughly developed in the same locations of paleo-ice stream pathways, where the depth to bedrock increases, are most probably due to the intensive glacial erosion. Variations in bedrock surface elevation beneath the Quaternary cover can provide essential information for the identification of erosional processes during past glaciations (Dürst-Stucki and Schlunegger, 2013). However, hypsometric technique alone cannot offer conclusive evidence on the process that is responsible for the land surface modifications because many processes can have very similar imprints on the topography.

\subsection{Tectonic controls on the lateral channel migration}

Our findings obtained from the analysis of TTSI indicate that most of the studied catchments of the study area are asymmetric and characterized by uniform patterns of lateral channel migration (Figs. 6 and 7). Remarkably, both the domains show a great similarity in the prevailing directions of channel migration toward SE and NW (sets-1\&-3 of Fig. 6a and sets-1\&-2 of Fig. 7a). They differ, however, in the presence of other main trends of channel migration toward SW within the domain-I (sets-2, Fig. 6a) and toward $\sim \mathrm{W}$ and $\sim \mathrm{E}$ within the domain-II (sets-3\&-4 of Fig. 7a). Growing body of research demonstrates that the lateral migration of river would be useful to infer the direction of tectonic tilting if the other influencing factors, e.g., lithology and glacial erosion, remain neutral (Alves et al., 2018; Cox, 1994; Cox et al., 2001; Ibanez et al., 2014; Salvany, 2004). Thus, a common problem that faces us is to discriminate between channel migrations driven by tectonics or by the lithological variations and glacial erosion. The abundant presence of glacial erosional features, such as roches moutonées and drumlins, in many parts of the study area makes it extremely difficult to differentiate between the influence of glacial and tectonic processes. 

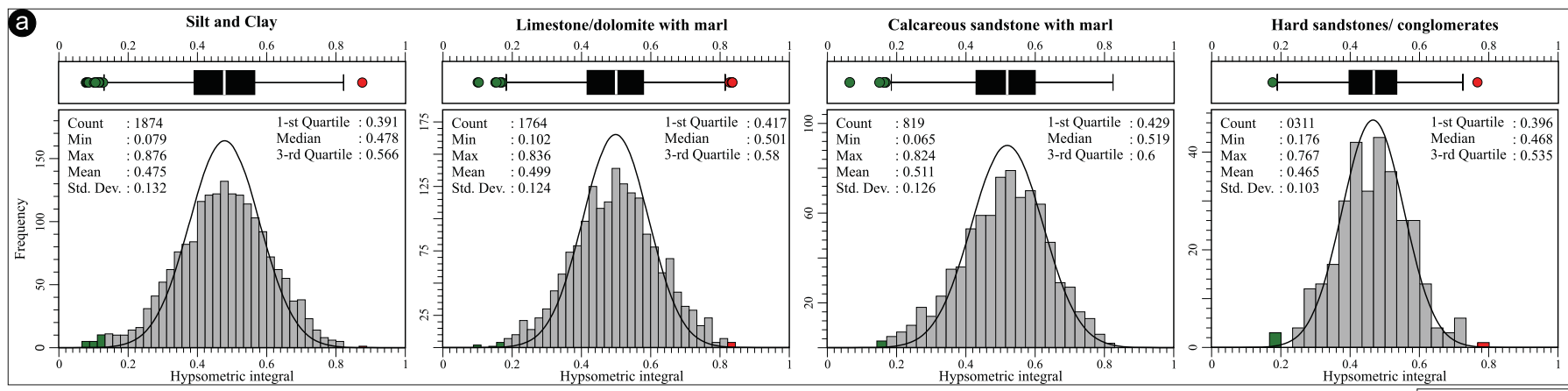

b

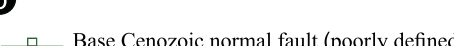

$\ldots \_$Base Cenozoic normal fault (poorly defined)
$\_$_ Base Cenozoic thrust fault (poorly defined)

- Base Cenozoic normal fault

$\leftrightharpoons$ Sinistral strike-slip fault (observed)

........ Sinistral strike-slip fault (supposed)

$\rightleftharpoons$ Dextral strike-slip fault (observed)

.......... Dextral strike-slip fault (supposed)

$\triangle \wedge$ Thrust

— Syncline

$\longrightarrow$ Anticline

$\square$ Lakes

City
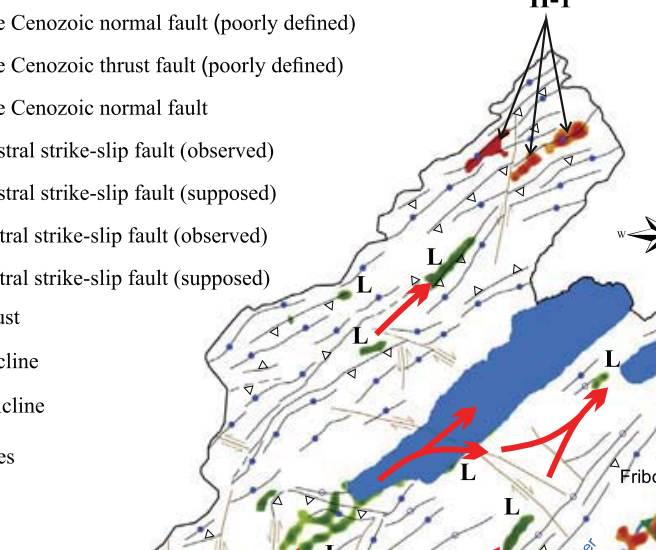

H-1

c

High hypsometric integral values (residual values after lithology filter)

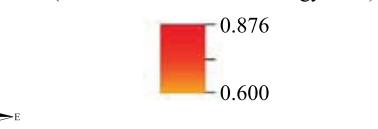

Low hypsometric integral values (residual values after lithology filter)

Fig. 9. Hypsometric integral values versus lithology and ice thickness distribution. a) Box plots and frequency histograms (lithological-filtering) showing the normal and abnormal values of the hypsometric integral for each host rock lithology. Most of the hypsometric integral values in all lithological units are roughly clustered around their mean values of $\sim 0.5$, highlighting the significant impact of lithology on the hypsometry. b) Spatial distribution of abnormal hypsometric integral values (labelled H-1, H-2, H-3, and L), superimposed on a simplified sub/surface tectonic elements of the westernmost of Switzerland. c) Ice thickness distribution during the last glacial maximum (LGM, 24,000 years ago) covered large parts of the study area (Bini et al., 2009). Unusually high values of the hypsometric integral (H-1and H3) are shown to be related to the hanging walls of the thrust faults, while unusually low values (L) are shown to be related to glacial erosion.

Furthermore, the effect of lithology can't be neglected, especially in many drainage catchments, where the spatial variations in their underlying rock properties appear to be non-uniform (e.g., catchment no. 41, 42, 43, and 45 Fig. 10a).Despite the difficulties in assessing the impacts of lithological variations and glacial erosion on the fluvial landscapes, most of the bedding planes within both domains are slightly dipping toward SE and NW directions (Fig. 10b and c). The latter are in agreement with the dominant directions of channel migration shown in Fig. 6a (sets-1\&-3) and Fig. 7a (sets-1\&-2). This fact generally supports findings from previous studies (Chittenden et al., 2013; Nunes et al., 2015) that imply that landscape properties in many basins within the Central European Alps are highly controlled by the tectonic architecture of the underlying bedrock. It could also support our hypothesis that tectonic processes have caused lateral tilting of the ground surface in a direction parallel to the direction of maximum compressive stress. Such behaviour of lateral ground tilting dates back to any time after the beginning of deformation in the Jura Mountains and Molasse Basin (Miocene time).

\subsection{Fault-induced uplift, stream migration and deflection}

Possible tectonic control can be observed in the drainage system located in the vicinity of known structures. A first example is given by the catchments (no. 23, 26, 35, 44, 67, 68, 69, 71, 72 and 74, Fig. 11a) that are located immediately in the south (hanging wall) and north (footwall) sides of Frontal Alpine thrust fault system. The catchments (no. 35, 44, 69, 71, and 74) located immediately in the hanging wall of the Frontal Alpine thrust fault display SE to $S$ directed migration for 
a

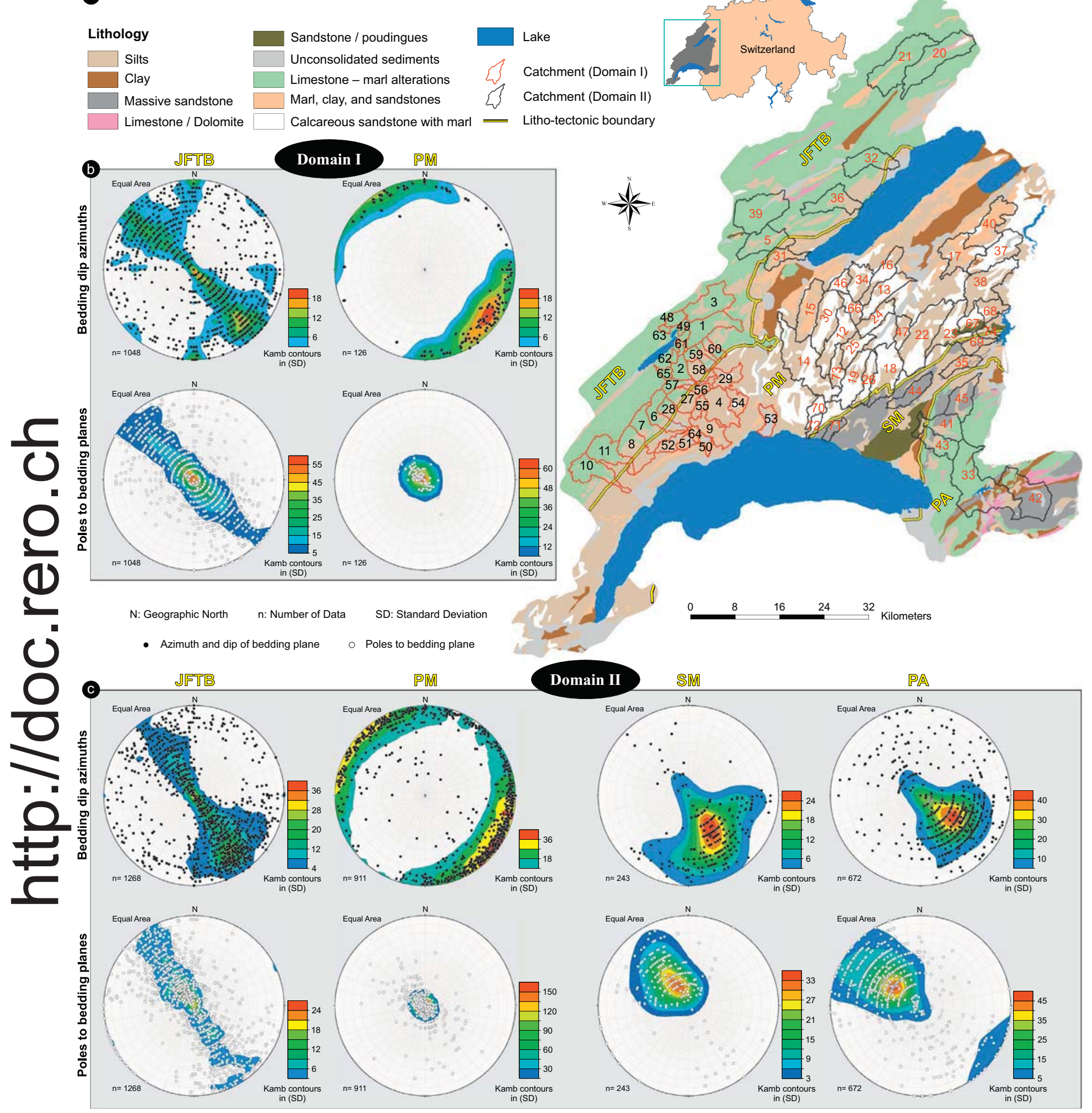

Fig. 10. (a) Catchment outlines superimposed on the main lithological units of the study area. (b) \& (c) Kamb contour diagrams (Equal-Area, lower hemisphere) of dip direction of the bedding planes and poles to bedding planes, displaying that the exposed beds in the catchments of both domains show gentle to moderate dips mostly toward SE and NW. These directions are in agreement with the dominant directions of the lateral stream migration (sets- $1 \&-3$ of Fig. 6 a and sets-1\&-2 of Fig. 7a). Lithological information as well as the measurements of the bedding planes obtained from Swisstopo. JFTB: Jura fold-thrust belt; PA: Prealps; PM: Plateau Molasse; SM: Subalpine Molasse.

their principal streams (Fig. 11a) coinciding almost with high hypsometric integral values (Fig. 11b), whereas most of those located immediately in the footwall of the Frontal Alpine thrust fault (no. 23, 67, 68, and 70) show almost NW migration for their principal streams
(Fig. 11a) with medium to relatively high hypsometric integral values (Fig. 11b).

Secondary tributaries within each wall also vary in their length. In the hanging-wall catchments (no. 35, 44, 69, 71, and 74), the 


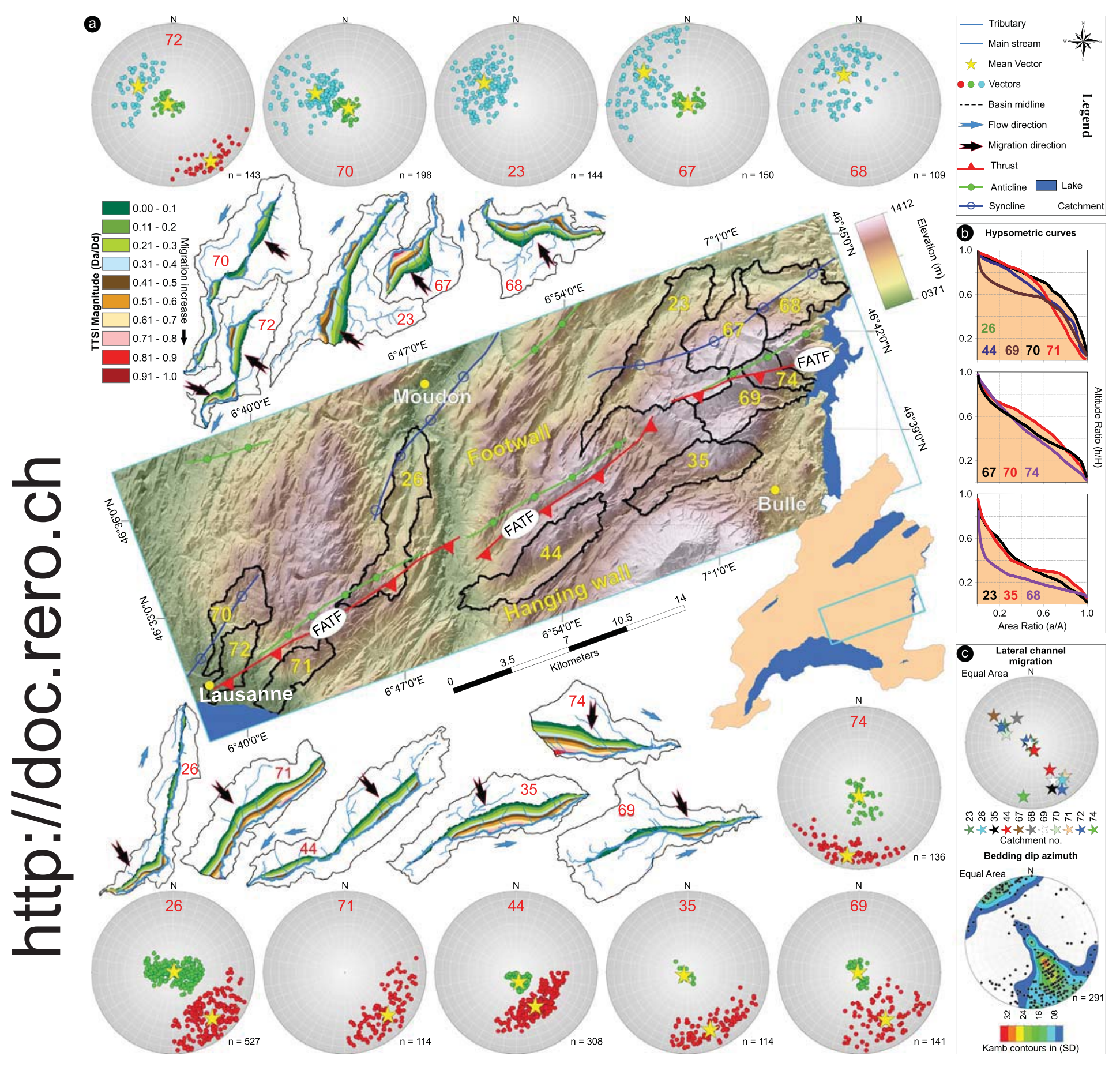

Fig. 11. Possible influence of thrusting movement along Frontal Alpine thrust fault system (FATF) on the development of drainage system. (a) Background image showing the locations of the FATF and the studied catchments. Insert map showing the geographical location of the FATF and surrounding areas. Polar diagram (equal-area, lower hemisphere) resulting from the TTSI analysis for each catchment. The yellow-star in the polar graph represents the preferred direction of the principal channel migration for each catchment. Keys for polar plot are the same as those in Fig. S.4b. The color-coding grid represents a range of TTSI magnitude values from 0 (no migration) to 1 (maximum migration). Black arrows represent the lateral migration directions, whereas blue arrows indicate the water flow directions. (b) Different patterns of hypsometric curves for the given catchments. Several catchments have high hypsometric integral values with convex-upwards hypsometric curves, indicating an important volume of original rock mass has not yet eroded (Strahler, 1952). (c) Lower hemisphere, Kamb contour plot of the dip azimuths of bedding within the studied catchments (Swisstopo data) showing dominant SE and NW directions, which are in agreement with the directions of lateral channel migrations. All the polar plots were plotted using Stereonet v9.9.6 (Allmendinger et al., 2011; Cardozo and Allmendinger, 2013). SD: Standard deviation. (For interpretation of the references to color in this figure legend, the reader is referred to the web version of this article.)

tributaries in the north bank are longer than those in the south bank (Fig. 11a), whereas in the footwall catchments (no. 23, 67, 68, and 70), the tributaries in the south and southeast bank are longer than those in the north and northwest bank (Fig. 11a).

These facts, however, are the most likely result from tectonic tilting and uplifting caused by the Frontal Alpine thrust fault (Fig. 12a). In more detail, the thrusting movement along the Frontal Alpine thrust fault has uplifted and tilted the hanging-wall toward the S and SE, where the catchments (no. 35, 44, 69, 71, and 74) are located (Figs. 11a and 12a), and associated with NW- tilted footwall, where the 


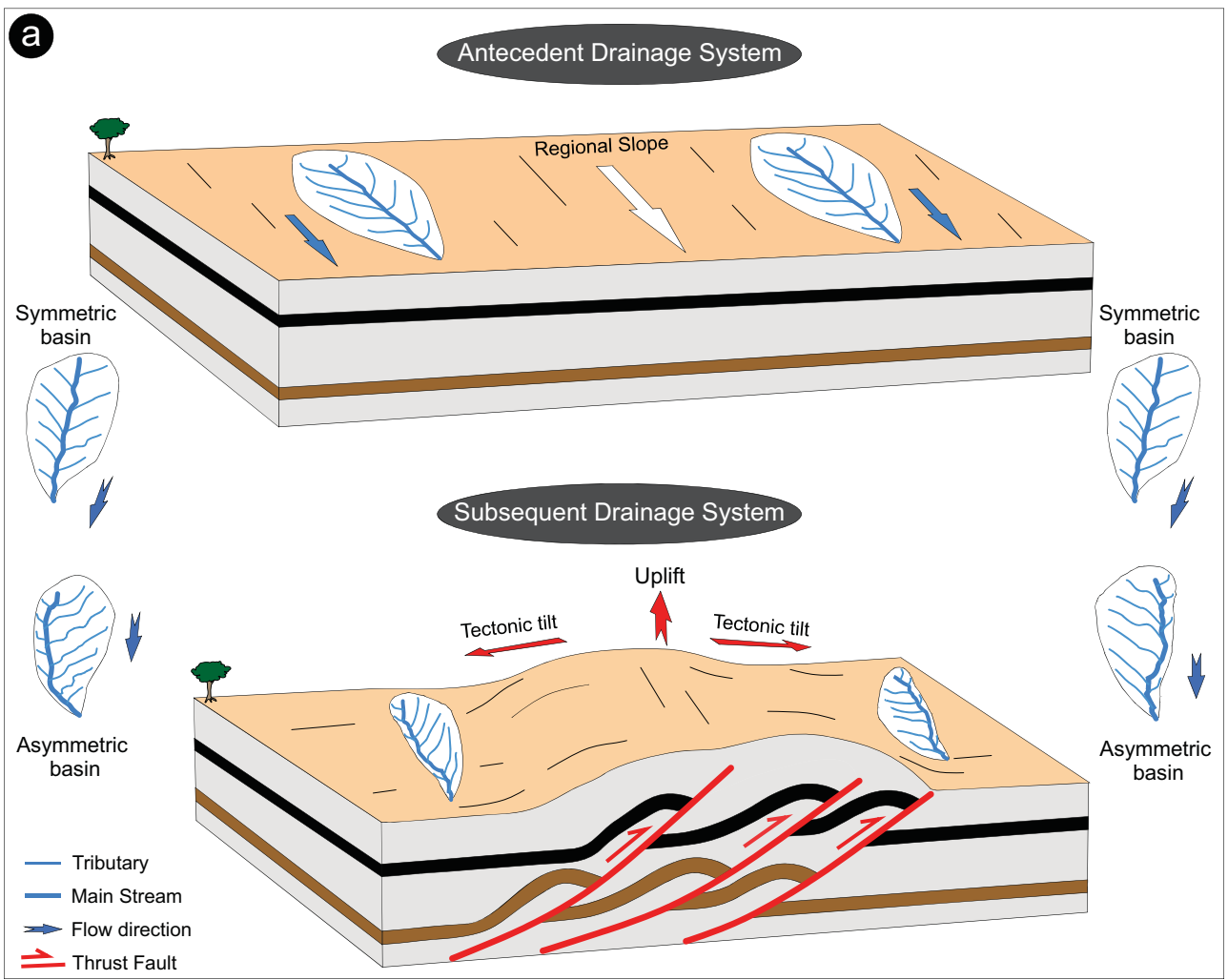

Fig. 12. Schematic cartoons showing a possible interpretation for the observations presented in Figs. 11 and 13. It is worth mentioning here that there is uncertainty in when and how both the lateral channels migration and the main-channel flow deflection were occurred. (a) Schematic showing possibly how the principal channels of the catchments in the hanging- and foot-walls of the Frontal Alpine thrust fault system (FATF, Fig. 11a) have responded to the tectonic movement by moving away from the catchment's midlines toward the catchment's margins. The length of tributaries on one side of the catchment increased after the thrusting movement relative to those on the other side. (b) Schematic showing the possible tectonic scenario for the deflection of the mainchannel flow of the less eroded catchment no. 14 (Fig. 13). The main-channel flow was sharply deflected toward NE direction against the regional slope, probably in response to oblique-slip movement along the fault plane.

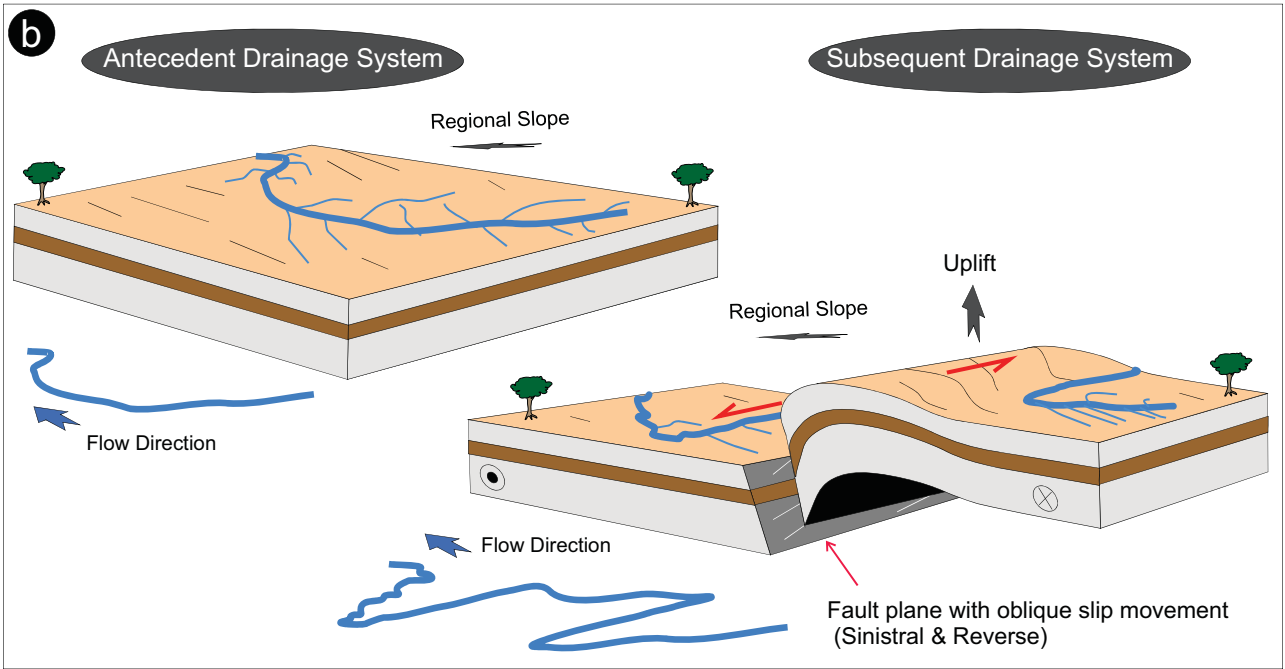

catchments (no. 23, 67, 68, and 70) are located (Figs. 11a and 12a).

The less-eroded catchment no. 72, located in the hanging and foot walls of the Frontal Alpine thrust fault (Fig. 11a), shows NW and SE -directed migration for the upper and lower parts of its main channel, respectively. This pattern of migration can be explained by the intervention of the Frontal Alpine thrust fault that caused NW- tilted footwall and SE-tilted hanging-wall, where the upper and the lower parts of the catchment are respectively located. The upper part of the catchment no. 26 shows SE -directed migration for its main channel (Fig. 11a) that is most likely as a result of tectonic tilting caused by the intervention of Frontal Alpine thrust fault. Since the initiation of thrusting and folding in the Subalpine Molasse occurred during the Miocene times (Burkhard, 1990; Mock et al., 2019; Ortner et al., 2015; Pfiffner, 2014; von Hagke et al., 2012), the maximum age limit for the channel migrations here dates back to the late Miocene or early Pliocene times. Another example of possible structural control on drainage systems is shown by the catchments (no. 14, 15, and 30) in the close vicinity of Essertines fault
(EF, Fig. 13a). The catchments (15 and 30), which located on opposite sides of the Essertines fault, respectively show west- and eastward lateral movements for their principal channels (Fig. 13b) with high hypsometric integral values (Fig. 13c). This could be due to oblique-slip movement along the Essertines fault with a dominant sinistral strikeslip component, which is presumably accompanied with ground-surface tilt. According to the stratigraphic position of the affected rocks (Aquitanian Lower Freshwater Molasse unit), the maximum age of this deformation dates back to middle/late Miocene time.

A remarkable drainage deflection within the catchment no. 14 is further evidence that supports the role of the Essertines fault in the development the drainage catchments (Fig. 13a). Due to the intervention of NNE-SSW trending Essertines fault, the main channel flow of the catchment no. 14 was sharply deflected $\sim 4.5 \mathrm{~km}$ toward NE direction against the regional NW gradient (Fig. 12b). The deflection of river courses in the place where faults interact can generally provide compelling evidence for the role of tectonics in fluvial landscape 


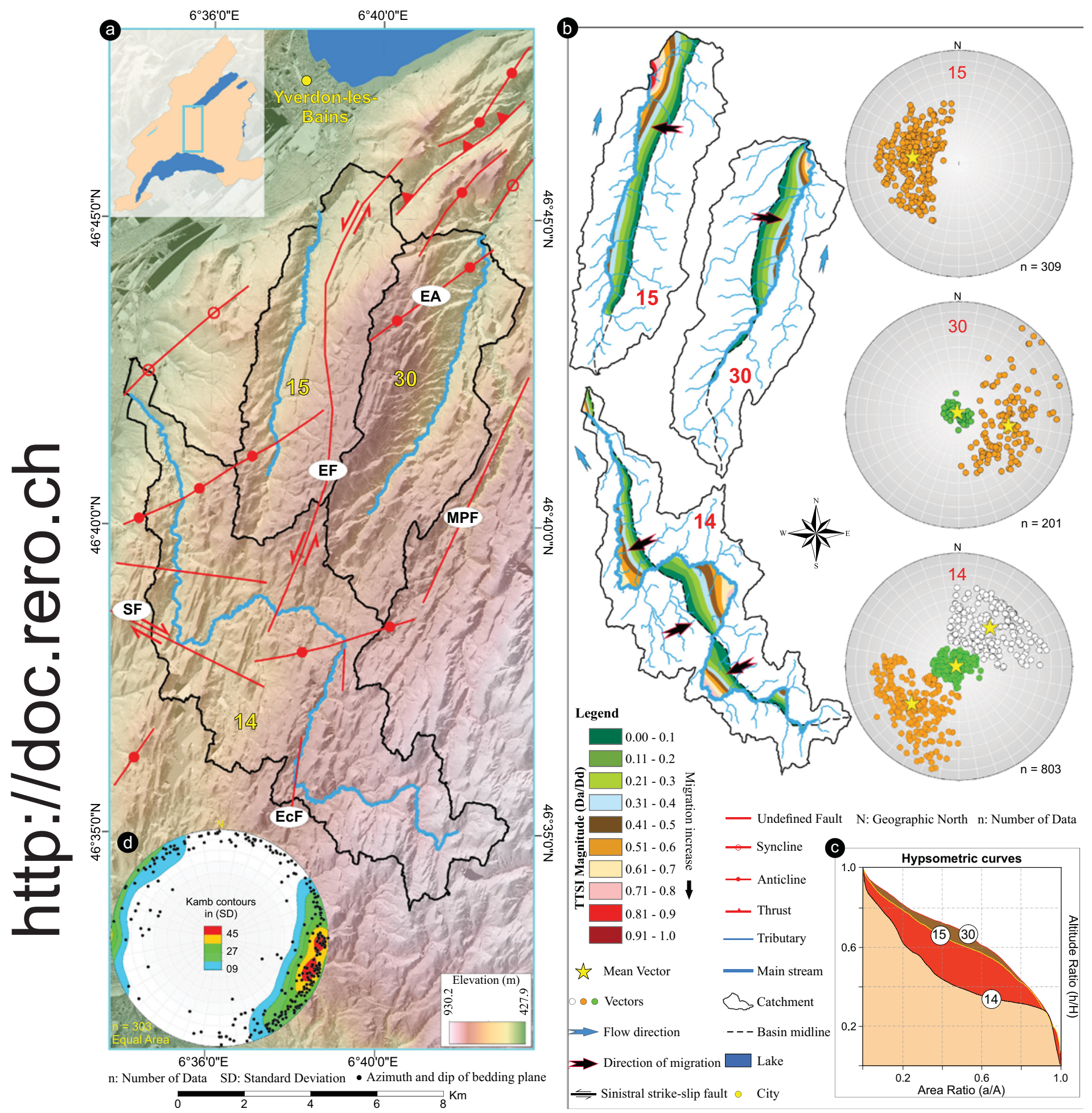

Fig. 13. Possible effects of tectonic activity along Essertines fault (EF) on the development of drainage systems. (a) Flow direction grid showing three catchments located immediately in the vicinity of EF. (b) Direction of lateral channel migration indicated by polar plot and color coding grid. Keys for polar plot are the same as those in Fig. S.4b. The color-coding grid represents a range of TTSI magnitude values from 0 (no migration) to 1 (maximum migration). (c) Hypsometric curves for the given catchments. (d) Lower-hemisphere, Kamb contour plot of the dip azimuths of bedding within the studied catchments (Swisstopo data) showing dominant $\sim \mathrm{E}$ and $\sim \mathrm{W}$ dip directions, which are respectively in agreement with east and westward migration of the principal channel of the catchments no. 30 and 15 . Possible oblique-slip movement along the EF caused lateral migration for the principal channels of the catchments 15 and 30, and deflected the mainstream flow of the catchment 14 against the general slope direction (see Fig. 12b). All the polar plots were plotted using Stereonet v9.9.6 (Allmendinger et al., 2011; Cardozo and Allmendinger, 2013). EA, Essertines-Chêne-Pâquier Anticline; EcF, Echallens Fault; MPF, Menthue-Prahins Fault; SF, La Sarraz Fault. 
development (Leeder and Jackson, 1993; Malik and Mohanty, 2006; Selvakumar and Ramasamy, 2014).

Therefore, the occurrence of drainage deflection and the presence of the lateral channel migration, together with convex-up to S-shaped hypsometric curves (high hypsometric integral) may shed light on the tectonic activities along the Essertines fault that took place at any time after middle Miocene.

\subsection{Reactivation of Mesozoic structures during Mio-Quaternary times}

Credible evaluative arguments about the reactivation of inherited faults may convince in the places where the location of anomalies in the river longitudinal profiles coincide with the locations of sub/surface faults, distinct changes in geophysical gradients, and significant topographic relief. Anomalies in the river longitudinal profiles, especially those related to SL index, are widely used as useful indicators to assess short-term tectonic activity (Chen et al., 2003; Delcaillau et al., 2011; Demoulin, 2010; Font et al., 2010; Hack, 1973; Ul-Hadi et al., 2012). Nonetheless, tectonic activity is not unique and other effects, particularly erodibility contrasts between different lithological units and slope instability (landslide damming), can also cause perturbations along the river course (Chen et al., 2003; Chittenden et al., 2013; El Hamdouni et al., 2010; Goldrick and Bishop, 2006; Hack, 1973; Harkins et al., 2005; Korup, 2006; Korup et al., 2006; Korup et al., 2010; Miller, 1991; Schlunegger, 2002; Seeber and Gornitz, 1983; Stutenbecker et al., 2015, 2016; Troiani et al., 2014). Therefore, to segregate the imprint of tectonics on the present-day fluvial landscape and assess our hypothesis that tectonic deformation causes a proportional increase in the river channel gradients, the lithology and landslides effects should be taken into consideration.

The Broye, Glane, and Le-Veyron rivers flow over four different bedrock lithologies, namely the well-consolidated sandstones, calcareous sandstone with marl interbeds, limestone-marl alterations, and silt/clay deposits. Although there are common (recurrent) values of SL for each bedrock lithology, there are some others showing considerable variability and spread (Fig. 14a). These statistical outliers are detected in all lithologic units except limestone-marl alterations (Fig. 14a) and found in zones B0, B1, B2, G1, G2, G3, G4, V1 and V2 (Fig. 14b).

Fig. 15 shows the spatial distribution of abnormal SL values (remaining SL anomalies after lithological filter) with respect to other known geological features. Many of the remaining SL anomalies that are observed in the areas of lateral changes in lithologic composition (black stars in Fig. 15), are most likely the result of local contrasts in bedrock erodibility. The rest of the remaining SL anomalies (indicated by red asterisks in Fig. 15) can directly be linked to landslide and/or tectonic processes. However, it is hard, if not impossible, to distinguish SL anomalies caused by landslide from those caused by tectonics since the latter, which is often accompanied with occurrence of several geological phenomena such as tilting and shaking of the ground surface, can easily induce gravitational slope failures couple with landslide activities (e.g., Chittenden et al., 2013; Gori et al., 2013; Jibson, 1996; Korup, 2006; Korup et al., 2006; Li et al., 2014; Nunes et al., 2015; Ouimet, 2009). With the availability of high-precision airborne LiDAR data, the identification of the spatial location of landslides is now possible.

The abnormal distribution of SL within zone B0 (red stars in Fig. 15a) is developed in areas of gentle to moderate tilted strata (Fig. 16a) that were influenced by the thrusting motion along the Frontal Alpine thrust fault, and struck by multiple earthquakes (Fig. 15a). No landslides were observed in these areas using the Swisstopo LiDAR data. Therefore, such abnormalities most likely resulted from the tectonic activities along the Frontal Alpine thrust fault. The abnormal distribution of SL within zone B2 (red star in Fig. 15a) is associated with a distinctive topographic change and a deeply incised valley (at profile distance $\sim 15 \mathrm{~km}$, Fig. 8 a). It also coincides in the space with a prominent change in the thickness of Cenozoic deposits (at profile distance $\sim 15 \mathrm{~km}$ Fig. $8 \mathrm{e}$ ) with a remarkable change in the geophysical properties (Fig. $8 \mathrm{c}$ and d), and is not spatially associated with landslides. These observations may suggest that there is an interaction between fluvial landscape and tectonic reactivation of subsurface thrust fault, which is lurking in the immediate vicinity of river segment (yellow asterisk in Fig. 15a). This interaction could also be supported by the occurrence of several earthquakes in the vicinity of zone B2 (red star in Fig. 15a). The abnormal distribution of SL in GI (Fig. 15b) are developed in the area where the Glane river is draining over pre-Cenozoic thrust fault (Gruber, 2017). Therefore it may occur as a result of tectonic reactivation of subsurface fault, which coincides in space with several faults cutting the middle Miocene deposits (Fig. 16c), during late Miocene to Quaternary times. The extreme SL values along zone G3 (Fig. 15b) have taken place in an area where no obvious landslide was observed. This area is characterized by unusual high values of the hypsometric integral (H-2 in Fig. 9b), by a significant decrease in the depth of the Mesozoic rocks (Supplementary Fig. S.6e), and by relatively high Bouguer gravity values (Supplementary Fig. S.6c) that do not increase gradually as residual aeromagnetic values. Standard deviation values increase significantly for a few kilometres across this zone before they begin decreasing again (Supplementary Fig. S.6a), indicating that the valley section becomes noticeably more incised. These observations suggest that the extreme values of SL could be the result of the tectonic uplift caused by reactivation of pre-existing thrust fault.

In the lowest part of the Glane river near the confluence with the Sarine River, extreme SL values are noted within a deep incised valley (G4, Fig. 15b) where no landslide mass was identified. These values could therefore be the result of tectonic activity.

The abnormalities of SL values within zone V1 (red star in Fig. 15c), which are noted over deeply-rooted Mesozoic fault (Meier, 2010), are associated with a considerable variations in the river incision (profile distance between $\sim 8$ to $\sim 14 \mathrm{~km}$, Fig. S.7a in the supplementary data) and coincide in the space with a remarkable change in the thickness of Cenozoic deposits (Supplementary Fig. S.7e) and in the geophysical properties (Supplementary Figs. S.7c and S.7d). This suggests that they are most likely caused by subsurface fault reactivation, regardless of its original type, which coincides in space with several faults cutting the middle Miocene deposits (Fig. 16d) and occurrence of a number of earthquakes. The reactivation of some pre-existing faults in the Swiss Molasse Basin has been documented by recent studies (e. g., Mock and Herwegh, 2017).

\section{Conclusions}

This work represents one of very few avenues for documenting and assessing the impact of tectonic activity on the development of fluvial landscapes in the westernmost of Switzerland. Our analysis is mainly based on the combined use of several classical geomorphic indices, including Hypsometric curves, Transverse Topographic Symmetry Index (TTSI), and channel's bottom gradients (SL index).The results show that the hypsometric attributes (integral, skewness and kurtosis) are particularly useful for detecting subtle differences in the shape of the hypsometric curves, and thus fluvial landscapes. It also show that the hypsometric technique alone can't provide sufficient information to determine the process that is responsible for a substantial modification in topographic characteristics of landscape, because many processes can have very similar imprints on the topography. Lithology filter approach through statistical analyses enables us to highlight several abnormalities in the spatial distribution of hypsometric integral and SL that have not been previously defined. Extremely high hypsometric integral values are spatially occurred on the hanging walls of the thrust faults, whereas the extremely low ones are observed in the areas where palaeo-ice stream pathways were posited.

The abnormal spatial distribution of SL values, supported by the available geological and geophysical data, not only enables us to mark 

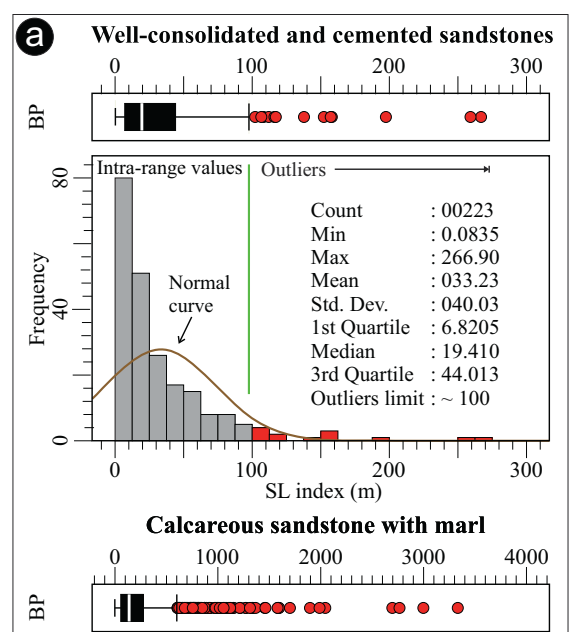

ले
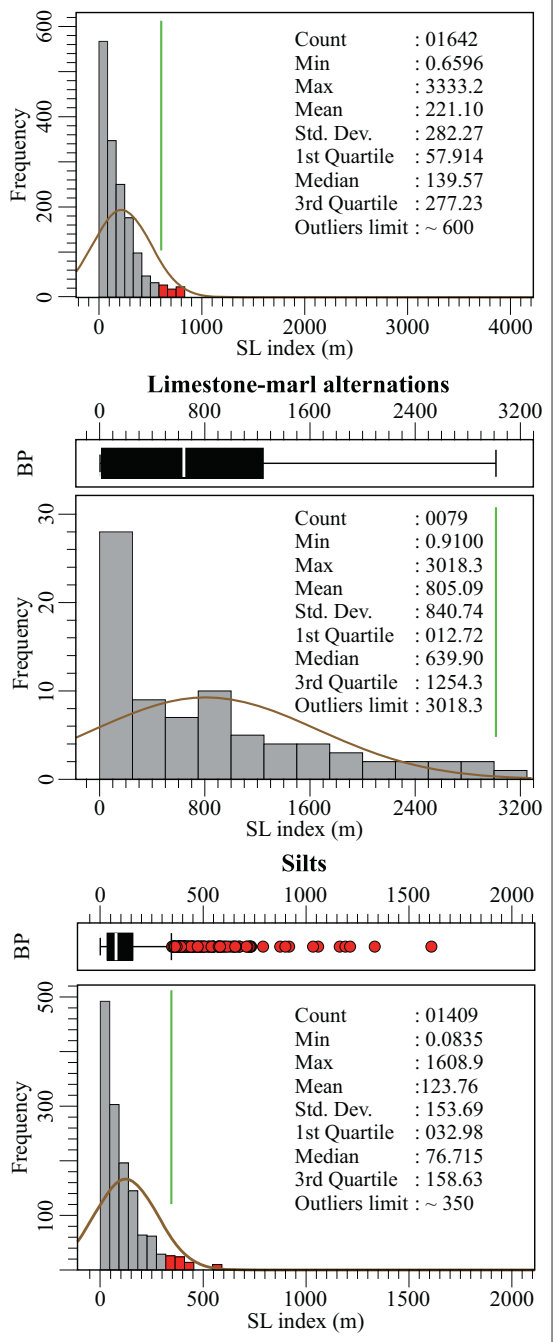

b

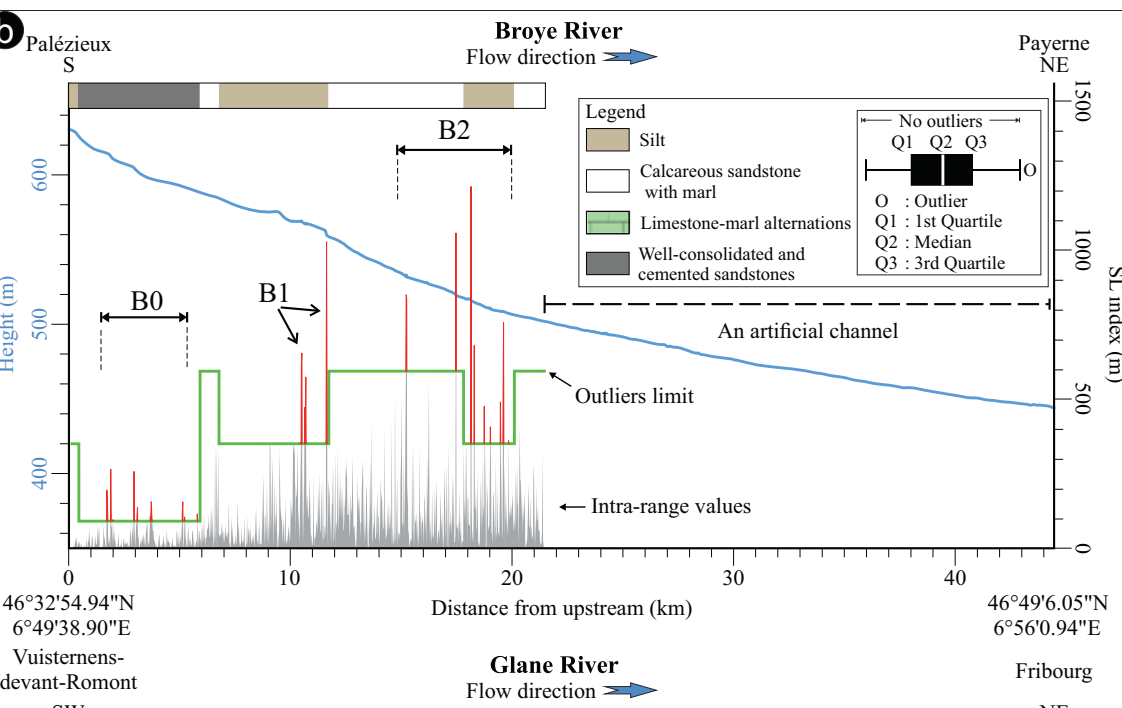

devant-Romont

SW
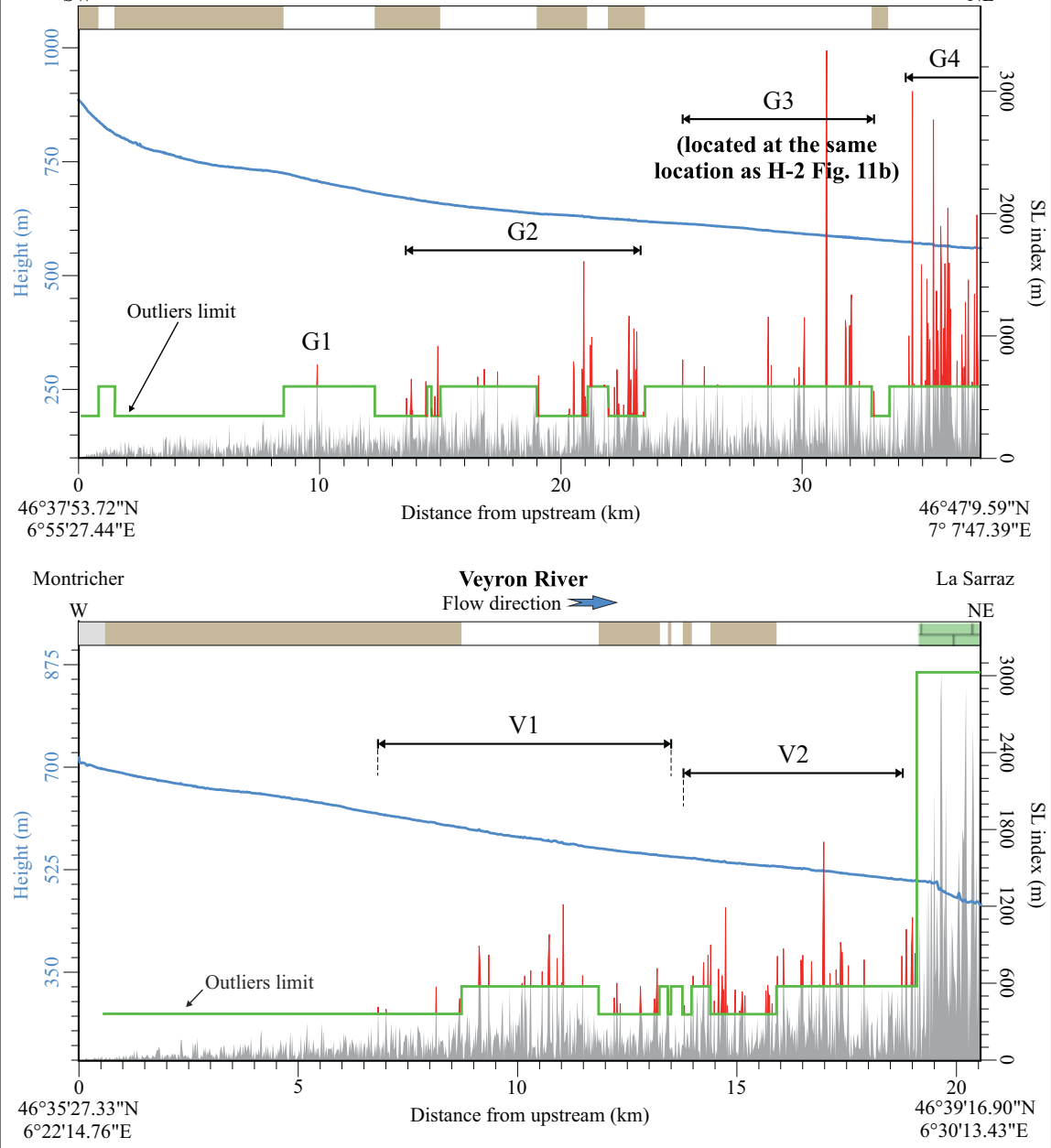

Fig. 14. Statistical characterization of SL values for each bedrock lithology beneath the studied parts of Broye, Glane, and Veyron rivers. (a) Frequency histograms and box-plots (lithological-filtering) showing the normal and abnormal values of SL for each host rock lithology. (b) Longitudinal profiles based on the channel's bottom elevation and gradient (SL index) showing threshold limit between normal and abnormal values of SL. Only abnormal values were taken into consideration and represented in the Fig. 15.

out the influence of tectonic on the landscape development, but also gives us possible clues about the reactivation of some inherited faults. In particular, high topographic relief, high values of fluvial incision, and high anomalous values of SL that almost coincide in space with remarkable changing in the depth of the subsurface geologic layers and in the geophysical properties, are exactly observed in the areas where the river flows above blind and emergent faults. These changes support the idea that the reactivation of some inherited fault zones played a crucial role in the development of present-day drainage systems.

Furthermore, the observations obtained from TTSI analysis also 


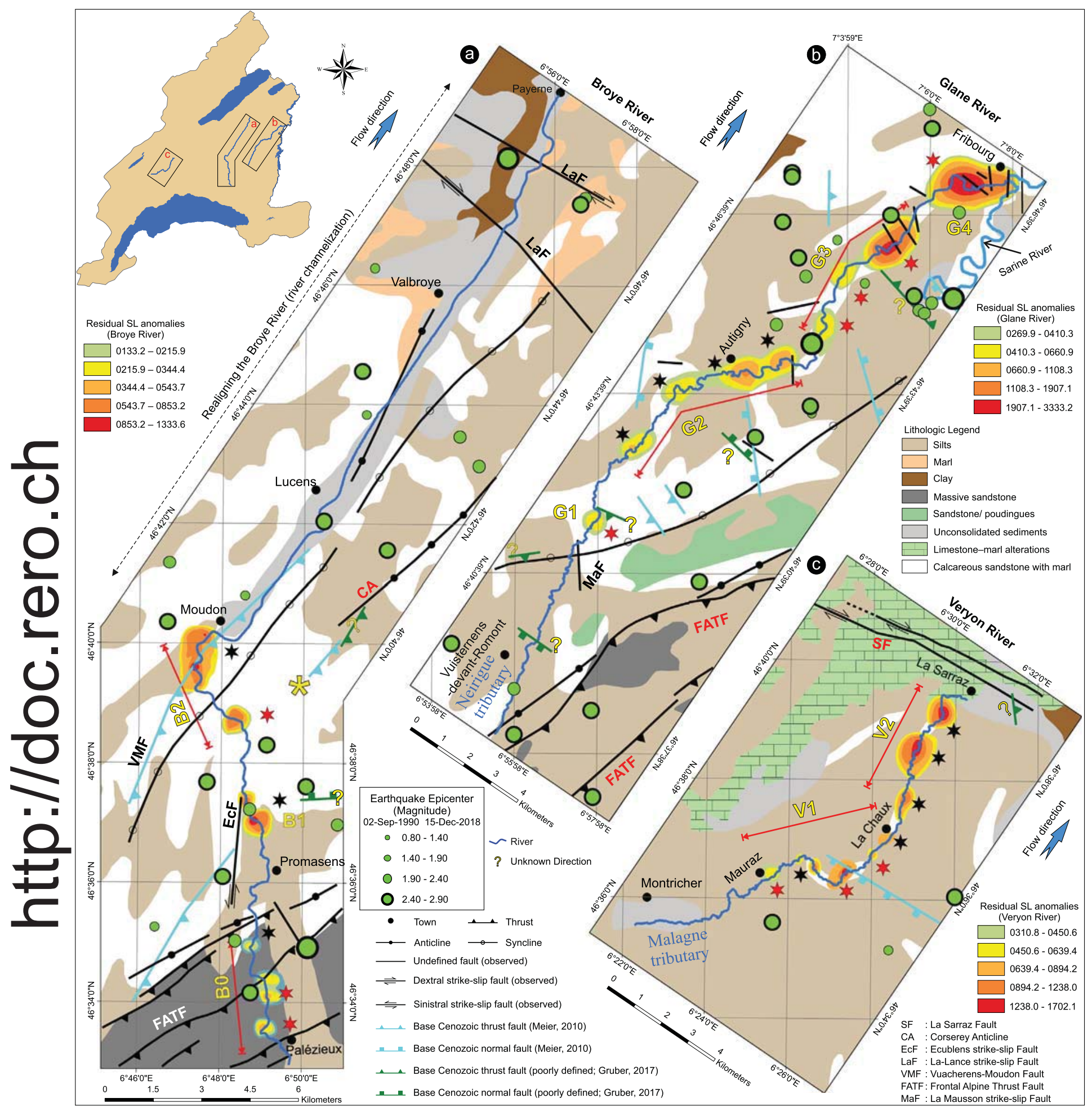

Fig. 15. Residual SL anomalies after the lithological-filtering for the studied parts of (a) Broye, (b) Glane, and (c) Veryon rivers. The black-colored stars indicate the SL anomalies associated with local contrasts in bedrock erodibility, while red-colored stars indicate the SL anomalies related to tectonic processes. Earthquake epicenters obtained from IRIS - Incorporated Research Institutions for Seismology (https://www.iris.edu/hq/). (For interpretation of the references to color in this figure legend, the reader is referred to the web version of this article.)

provide important clues about the role of tectonic on the modification of fluvial landscape, despite the great uncertainty posed by the impacts of lithology variation and glacial erosion during the last glacial cycle. In more detail, we find a general positive correlation between the preferred directions of channel migration and dominant dip azimuths of bedding planes within the area of study toward SW and NW, reflecting possible land-surface tilted due to tectonic forcing. Our results also show that lateral ground-tilting associated with Frontal Alpine thrust fault is likely responsible for the asymmetric geometry of many drainage basins. We can conclude that the analysis of the geomorphic indices combined with the geological and geophysical clues provides new and valuable insights to assess the effects of tectonics on the 

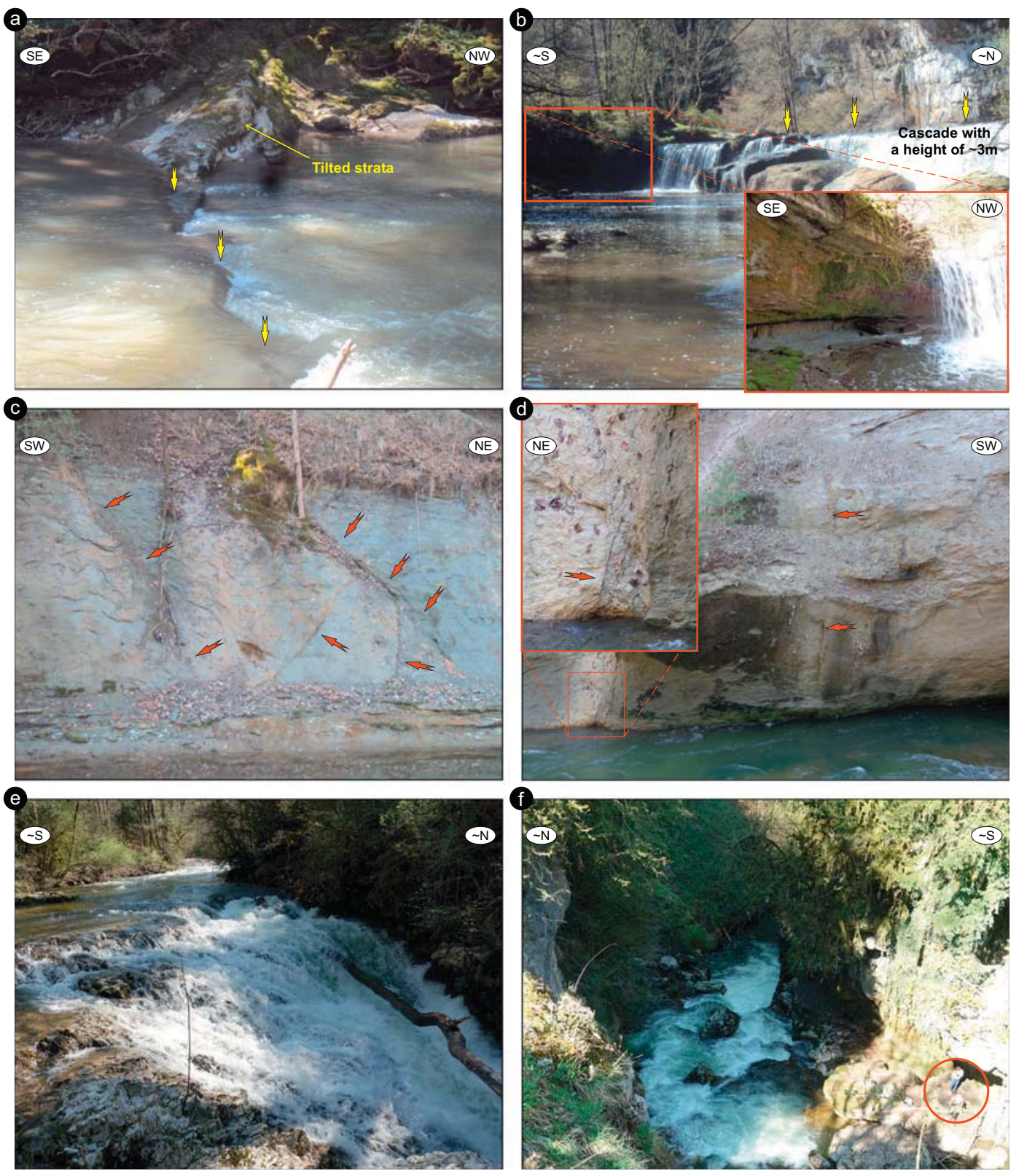

Fig. 16. Field photos showing spatial variations in channel bottom gradients of several rivers in the westernmost of Switzerland and evidence of late Miocene/early Pliocene tectonic faulting. Abrupt variations of channel bottom gradients can be explained by the tectonic processes if other influencing factors, particularly variations in bedrock erodibility, remain neutral. (a) and (b) Upstream portion of the Broye river showing a change in its channel-floor gradient (marked by yellow arrows), located in zone B0 (at profile distance $\sim 3 \mathrm{~km}$, Fig. 14b) and in zone B1 (at profile distance $\sim 11.5 \mathrm{~km}$, Fig. 14b) respectively. (c) and (d) Several NW-SE trending faults with different dip angles (marked by red arrows) cutting Neogene Molasse sedimentary deposits on the left bank of the Glane river (zone G1 at profile distance $\sim 10 \mathrm{~km}$, Fig. 14b) and on the right bank of the Veyron river (zone V1 at profile distance $\sim 10.5 \mathrm{~km}$, Fig. 14b) while facing downstream, respectively. According to the stratigraphic ages of the affected rocks, the maximum age of these faults dates back to the late Miocene/early Pliocene. Downstream portion of the Veyron river showing (e) a steep channel with a prominent waterfall and (f) a deeply incised valley with a depth of $>10 \mathrm{~m}$ within Cretaceous sedimentary bedrock, located in zone V2 at profile distance $\sim 19 \mathrm{~km}$ (Fig. 14b). (For interpretation of the references to color in this figure legend, the reader is referred to the web version of this article.)

development of fluvial landscape in the area characterized by poor rock exposures.

Supplementary data to this article can be found online

\section{Acknowledgments}

We would like to warmly thank Prof. Fritz Schlunegger from University of Bern, and an anonymous reviewer, for their thoughtful and constructive comments that substantially improved the final version of this manuscript. We would also like to cordially thank Prof. Philippe Agard and his editorial colleagues for their expert editorial guidance. Furthermore, we would like to express our thanks to the Swiss government excellence scholarship program for financially supporting our project.

\section{References}

Affolter, T., Gratier, J.-P., 2004. Map view retrodeformation of an arcuate fold-and-thrust belt: The Jura case. Journal of Geophysical Research 109 (B3), B03404. https://doi. org/10.1029/2002JB002270. 
Allmendinger, R.W., Cardozo, N., Fisher, D.M., 2011. Structural Geology Algorithms: Vectors and Tensors. Cambridge University Press.

Alves, F.C., Rossetti, D.F., Valeriano, M.M., Filho, C.O.A., 2018. Neotectonics in the South American passive margin: evidence of Late Quaternary uplifting in the northern Paraiba Basin (NE Brazil). Geomorphology 325 (2019), 1-16. https://doi.org/10. 1016/j.geomorph.2018.09.028.

Anders, N.S., Seijmonsbergen, A.C., Bouten, W., 2009. Modelling channel incision and alpine hillslope development using laser altimetry data. Geomorphology 113 (1-2), 35-46. https://doi.org/10.1016/j.geomorph.2009.03.022.

Ariza-Villaverde, A.B., Jiménez-Hornero, F.J., Gutiérrez de Ravé, E., 2013. Multifractal analysis applied to the study of the accuracy of DEM-based stream derivation. Geomorphology 197, 85-95. https://doi.org/10.1016/j.geomorph.2013.04.040.

Ariza-Villaverde, A.B., Jiménez-Hornero, F.J., Gutiérrez de Ravé, E., 2015. Influence of DEM resolution on drainage network extraction: a multifractal analysis. Geomorphology 241, 243-254. https://doi.org/10.1016/j.geomorph.2015.03.040.

Armitage, J.J., Duller, R.A., Whittaker, A.C., Allen, P.A., 2011. Transformation of tectonic and climatic signals from source to sedimentary archive. Nat. Geosci. 4 (4), 231-235. https://doi.org/10.1038/ngeo1087.

Becker, A., Davenport, C.A., Giardini, D., 2002. Palaeoseismicity studies on endPleistocene and Holocene lake deposits around Basle, Switzerland. Geophys. J. Int. 149 (1), 659-678. https://doi.org/10.1046/j.1365-246X.2002.01678.x.

Becker, A., Ferry, M., Monecke, K., Schnellmann, M., Giardini, D., 2005. Multiarchive paleoseismic record of late Pleistocene and Holocene strong earthquakes in Switzerland. Tectonophysics 400 (1-4), 153-177. https://doi.org/10.1016/j.tecto. 2005.03.001.

Becker, J.J., Sandwell, D.T., Smith, W.H.F., Braud, J., Binder, B., Depner, J., et al., 2009. Global bathymetry and elevation data at 30 arc seconds resolution: SRTM30_PLUS. Mar. Geod. 32 (4), 355-371. https://doi.org/10.1080/01490410903297766.

Beyer, H.L., 2004. Hawth's Analysis Tools for ArcGIS. Retrieved April 24, 2018, from. http://www.spatialecology.com/htools/tooldesc.php.

Bini, A., Buoncristiani, F., Couterrand, S., Ellwanger, D., Fleber, M., Florineth, D., Graf, H.R., Keller, O., Kelly, M., Schlüchter, C., Schoeneich, P., 2009. La Suisse durant le denier maximum glaciaire (LGM). Map 1:500000. Federal Office of Topography Swisstopo, Switzerland.

Bishop, M.P., Shroder, J.F, 2000. Remote sensing and geomorphometric assessment of topographic complexity and erosion dynamics in the Nanga Parbat massif. In: Khan, M.A., Treloar, P.J., Searle, M.P., Jan, M.Q. (Eds.), Tectonics of the Nanga Parbat Syntaxis and the Western Himalaya. vol. 170. Geological Society, London, Special Publications, pp. 181-200

Bishop, P., Hoey, T.B., Jansen, J.D., Artza, LL., 2005. Knickpoint recession rate and catchment area: the case of uplifted rivers in Eastern Scotland. Earth Surf. Process. Landf. 30 (6), 767-778. https://doi.org/10.1002/esp.1191.

Borradaile, G., 2003. Statistics of Earth Science Data: Their Distribution in Time, Space, and Orientation. Springer, Berlin, Heidelberg.

Bournas, N., Bake, H.A., 2001. Interpretation of magnetic anomalies using the horizontal gradient analytic signal. Ann. Geophys. 44 (3), 505-526. https://doi.org/10.4401/ ag-3572.

Boyce, J.I., Morris, W.A., 2002. Basement-controlled faulting of Paleozoic strata in southern Ontario, Canada: new evidence from geophysical lineament mapping. Tectonophysics 353 (1-4), 151-171. https://doi.org/10.1016/S0040-1951(02) 00280-9.

Brocard, G.Y., van Der Beek, P.A., 2006. Influence of incision rate, rock strength, and bedload supply on bedrock river gradients and valley-flat widths: Field-based evidence and calibrations from western Alpine rivers (southeast France). In: Willett, S.D., Hovius, N., Brandon, M.T., Fisher, D. (Eds.), Tectonics, Climate, and Landscape Evolution. vol. 398. Geological Society of America, pp. 101-126.

Brocklehurst, S.H., Whipple, K.X., 2001. Glacial erosion and relief production in the Eastern Sierra Nevada, California. Geomorphology 42 (1-2), 1-24. https://doi.org/ 10.1016/S0169-555X(01)00069-1.

Brocklehurst, S.H., Whipple, K., 2004. Hypsometry of glaciated landscapes. Earth Surf. Process. Landf. 29 (7), 907-926. https://doi.org/10.1002/esp.1083.

Brocklehurst, S.H., Whipple, K.X., 2007. Response of glacial landscapes to spatial variations in rock uplift rate. Journal of Geophysical Research 112 (F2). https://doi.org/ 10.1029/2006JF000667.

Brookfield, M.E., 1998. The evolution of the great river systems of southern Asia during the Cenozoic India-Asia collision: rivers draining southwards. Geomorphology 22 (3-4), 285-312. https://doi.org/10.1016/S0169-555X(97)00082-2.

Burbank, D.W., Anderson, R.S., 2001. Tectonic Geomorphology. Blackwell, Oxford, UK.

Burbank, D.W., Anderson, R.S., 2011. Tectonic Geomorphology. John Wiley, Chichester, UK.

Burberry, C.M., Cosgrove, J.W., Liu, J.-G., 2010. A study of fold characteristics and deformation style using the evolution of the land surface: Zagros Simply Folded Belt, Iran. In: Leturmy, P., Robin, C. (Eds.), Tectonic and Stratigraphic Evolution of Zagros and Makran during the Mesozoic-Cenozoic. 330. Geological Society, London, Special Publications, pp. 139-154. https://doi.org/10.1144/SP330.8.

Burkhard, M., 1990. Aspects of the large-scale Miocene deformation in the most external part of the Swiss Alps (sub-Alpine molasse to Jura fold belt). Eclogae Geol. Helv. 83 (3), 559-583. https://doi.org/10.5169/seals-166602.

Burkhard, M., Sommaruga, A., 1998. Evolution of the western Swiss Molasse basin: structural relations with the Alps and the Jura belt. Geol. Soc. Lond., Spec. Publ. 134 (1), 279-298. https://doi.org/10.1144/GSL.SP.1998.134.01.13.

Buxtorf, A., 1907. Zur Tektonik des Kettenjura. Berichte U'ber Die Versammlungen Des Oberrheinischen Geologischen Vereins. 40, 97-111.

Cardozo, N., Allmendinger, R.W., 2013. Spherical projections with OSXStereonet. Comput. Geosci. 51, 193-205. https://doi.org/10.1016/j.cageo.2012.07.021.

Champagnac, J.-D., Schlunegger, F., Norton, K., von Blanckenburg, F., Abbühl, L.M.,
Schwab, M., 2009. Erosion-driven uplift of the modern Central Alps. Tectonophysics 474 (1-2), 236-249. https://doi.org/10.1016/j.tecto.2009.02.024.

Champagnac, J.-D., Molnar, P., Sue, C., Herman, F., 2012. Tectonics, climate, and mountain topography. Journal of Geophysical Research: Solid Earth 117 (B2). https://doi.org/10.1029/2011JB008348.

Chen, Y.-C., Sung, Q., Cheng, K.-Y., 2003. Along-strike variations of morphotectonic features in the Western Foothills of Taiwan: tectonic implications based on streamgradient and hypsometric analysis. Geomorphology 56 (1-2), 109-137. https://doi. org/10.1016/S0169-555X(03)00059-X.

Chittenden, H., Delunel, R., Schlunegger, F., Akçar, N., Kubik, P., 2013. The influence of bedrock orientation on the landscape evolution, surface morphology and denudation $(10 \mathrm{Be})$ at the Niesen, Switzerland. Surface Processes and Landforms 39 (9), 1153-1166. https://doi.org/10.1002/esp.3511.

Clark, M.K., Schoenbohm, L.M., Royden, L.H., Whipple, K.X., Burchfiel, B.C., Zhang, X., et al., 2004. Surface uplift, tectonics, and erosion of eastern Tibet from large-scale drainage patterns. Tectonics 23 (1), TC1006. https://doi.org/10.1029/ 2002 TC001402.

Claude, A., Akçar, N., Ivy-Ochs, S., Schlunegger, F., Kubik, P.W., Christl, M., Vockenhuber, C., Kuhlemann, J., Rahn, M., Schlüchter, C., 2019. Changes in landscape evolution patterns in the northern Swiss Alpine Foreland during the midPleistocene revolution. Geol. Soc. Am. Bull. 2019. https://doi.org/10.1130/ B31880.1.

Cloetingh, S., Cornu, T., Ziegler, P.A., Beekman, F., 2006. Neotectonics and intraplate continental topography of the northern Alpine Foreland. Earth Sci. Rev. 74 (3-4), 127-196. https://doi.org/10.1016/j.earscirev.2005.06.001.

Cooper, G.R.J., Cowan, D.R., 2007. Enhancing linear features in image data using horizontal orthogonal gradient ratios. Comput. Geosci. 33 (7), 981-984. https://doi.org/ 10.1016/j.cageo.2006.12.002.

Cox, R.T., 1994. Analysis of drainage-basin symmetry as a rapid technique to identify areas of possible Quaternary tilt-block tectonics: an example from the Mississippi Embayment. Geol. Soc. Am. Bull. 106 (5), 571-581. https://doi.org/10.1130/00167606(1994)106<0571:AODBSA > 2.3.CO;2.

Cox, R.T., Van Arsdale, R.B., Harris, J.B., 2001. Identification of possible Quaternary deformation in the northeastern Mississippi Embayment using quantitative geomorphic analysis of drainage-basin asymmetry. Geol. Soc. Am. Bull. 113 (5), 615-624. https://doi.org/10.1130/0016-7606(2001)113<0615:IOPQDI > 2.0.CO;2.

Cyr, A.J., Granger, D.E., Olivetti, V., Molin, P., 2010. Quantifying rock uplift rates using channel steepness and cosmogenic nuclide-determined erosion rates: examples from northern and southern Italy. Geological Society of America, Lithosphere 2 (3), 188-198. https://doi.org/10.1130/L96.1.

Delcaillau, B., 2001. Geomorphic response to growing fault-related folds: example from the foothills of central Taiwan. Geodin. Acta 14 (5), 265-287. https://doi.org/10. 1016/S0985-3111(01)01071-3.

Delcaillau, B., Deffontaines, B., Floissac, L., Angelier, J., Deramond, J., Souquet, P., et al., 1998. Morphotectonic evidence from lateral propagation of an active frontal fold; Pakuashan anticline, foothills of Taiwan. Geomorphology 24 (4), 263-290. https:// doi.org/10.1016/S0169-555X(98)00020-8.

Delcaillau, B., Carozza, J.-M., Laville, E., 2006. Recent fold growth and drainage development: the Janauri and Chandigarh anticlines in the Siwalik foothills, northwest India. Geomorphology 76 (3-4), 241-256. https://doi.org/10.1016/j.geomorph. 2005.11.005.

Delcaillau, B., Amrhar, M., Namous, M., Laville, E., Pedoja, K., Dugué, O., 2011. Transpressional tectonics in the Marrakech High Atlas: insight by the geomorphic evolution of drainage basins. Geomorphology 134 (3-4), 344-362. https://doi.org/ 10.1016/j.geomorph.2011.07.010.

Delunel, R., van der Beek, P.A., Bourlès, D.L., Carcaillet, J., Schlunegger, F., 2014. Transient sediment supply in a high-altitude Alpine environment evidenced through a 10Be budget of the Etages catchment (French Western Alps). Earth Surf. Process. Landf. 39 (7), 890-899. https://doi.org/10.1002/esp.3494.

Demoulin, A., 2010. Basin and river profile morphometry: a new index with a high potential for relative dating of tectonic uplift. Geomorphology 126 (1-2), 97-107. https://doi.org/10.1016/j.geomorph.2010.10.033.

van Der Beek, P., Bourbon, P., 2007. A quantification of the glacial imprint on relief development in the French western Alps. Geomorphology 97 (1-2), 52-72. https:// doi.org/10.1016/j.geomorph.2007.02.038.

Diehl, T., Clinton, J., Deichmann, N., Cauzzi, C., Kästli, P., Kraft, T., Molinari, I., Böse, M., Michel, C., Hobiger, M., Haslinger, F., Fäh, D., Wiemer, S., 2018. Earthquakes in Switzerland and surrounding regions during 2015 and 2016. Swiss J. Geosci. 111 (1-2), 221-244. https://doi.org/10.1007/s00015-017-0295-y.

Dilts, T., 2015. Polygon to Centerline Tool for ArcGIS. Retrieved April 24, 2018, from. http://www.arcgis.com/home/item.html?id = bc642731870740aabf48134f90aa6165.

Dortch, J.M., Owen, L.A., Schoenbohm, L.M., Caffee, M.W., 2011. Asymmetrical erosion and morphological development of the central Ladakh Range, northern India. Geomorphology 135 (1-2), 167-180. https://doi.org/10.1016/j.geomorph.2011.08. 014.

Dürst-Stucki, M., Schlunegger, F., 2013. Identification of erosional mechanisms during past glaciations based on a bedrock surface model of the central European Alps. Earth Planet. Sci. Lett. 384, 57-70. https://doi.org/10.1016/j.epsl.2013.10.009.

Duvall, A., Kirby, E., Burbank, D., 2004. Tectonic and lithologic controls on bedrock channel profiles and processes in coastal California. J. Geophys. Res. 109 (F3). https://doi.org/10.1029/2003JF000086.

El Hamdouni, R., Irigaray, C., Fernández, T., Chacón, J., Keller, E.A., 2007. Assessment of relative active tectonics, southwest border of the Sierra Nevada (southern Spain). Geomorphology 96 (1-2), 150-173. https://doi.org/10.1016/j.geomorph.2007.08. 004. 
El Hamdouni, R., Irigaray, C., Jiménez-Perálvarez, J.D., Chacón, J., 2010. Correlations analysis between landslides and stream length-gradient (SL) index in the southern slopes of Sierra Nevada (Granada, Spain). In: Williams, A.L., Pinches, G.M., Chin, C.Y., McMorran, T.J., Massey, C.Y. (Eds.), Geologically Active. Taylor and Francis Group, London, pp. 141-149.

Elo, S., Lanne, E., Ruotoistenmäki, T., Sindre, A., 1989. Interpretation of gravity anomalies along the POLAR Profile in the northern Baltic Shield. Tectonophysics 162 (1-2), 135-150. https://doi.org/10.1016/0040-1951(89)90360-0.

ESRI, 2011. Arc Hydro Geoprocessing Tools v. 2.0 (Tutorial). Environmental Systems Research Institute, Redlands, California, United States.

Evans, I.S., 1998. What do terrain statistics really mean? In: Lane, S.N., Richards, K.S., Chandler, J.H. (Eds.), Landform Monitoring, Modelling and Analysis. John Wiley, Chichester, UK, pp. 119-138.

Fairfield, J., Leymarie, P., 1991. Drainage networks from grid digital elevation models. Water Resour. Res. 27 (5), 709-717. https://doi.org/10.1029/90WR02658.

Ferraccioli, F., Bozzo, E., Damaske, D., 2001. Aeromagnetic signatures over western Marie Byrd Land provide insight into magmatic arc basement, mafic magmatism and structure of the Eastern Ross Sea Rift flank. Tectonophysics 347 (1-3), 139-165. https://doi.org/10.1016/S0040-1951(01)00242-6.

Fiebig, M., Preusser, F., 2008. Pleistocene glaciations of the northern Alpine Foreland. Geographica Helvetica 63 (3), 145-150. https://doi.org/10.5194/gh-63-145-2008.

Figueiredo, P.M., Rockwell, T.K., Cabral, J., Ponte, L.C., 2018. Morphotectonics in a low tectonic rate area: analysis of the southern Portuguese Atlantic coastal region. Geomorphology 326, 132-151. https://doi.org/10.1016/j.geomorph.2018.02.019.

Fiore, J., 2007. Quaternary Subglacial Processes in Switzerland: Geomorphology of the Plateau and Seismic Stratigraphy of Western Lake Geneva. PhD thesis In: Terre \& Environnement. vol. 69. Université de Genève, Switzerland, pp. 169. https://doi. org/10.13097/archive-ouverte/unige:714.

Florineth, D., 1998. Surface geometry of the Last Glacial Maximum (LGM) in the southeastern Swiss Alps (Graubünden) and its paleoclimatological significance. E\&GQuaternary Science Journal 48 (1), 23-37. https://doi.org/10.23689/fidgeo-1401.

Florineth, D., Schlüchter, C., 1998. Reconstructing the last Glacial Maximum (LGM) ice surface geometry and flowlines in the Central Swiss Alps. Eclogae Geol. Helv. 91, 391-407. https://doi.org/10.5169/seals-168431.

Font, M., Amorese, D., Lagarde, J.-L, 2010. DEM and GIS analysis of the stream gradient index to evaluate effects of tectonics: the Normandy intraplate area (NW France). Geomorphology 119 (3-4), 172-180. https://doi.org/10.1016/j.geomorph.2010.03. 017.

Fraefel, M., 2008. Geomorphic Response to Neotectonic Activity in the Jura Mountain and in the Southern Upper Rhine Graben (Doctoral dissertation). Retrieved from edoc. http://edoc.unibas.ch/diss/DissB_8560University of Basel, Switzerland.

Gao, M., Zeilinger, G., Xu, X., Tan, X., Wang, Q., Hao, M., 2016. Active tectonics evaluation from geomorphic indices for the central and the southern Longmenshan range on the Eastern Tibetan Plateau, China. Tectonics 35 (8), 1812-1826. https://doi.org/ $10.1002 / 2015$ TC004080.

García-Tortosa, F.J., Alfaro, P., Galindo-Zaldívar, J., Gibert, L., López-Garrido, A.C., Sanz de Galdeano, C., Ureña, M., 2007. Geomorphologic evidence of the active Baza Fault (Betic Cordillera, South Spain). Geomorphology 97 (3-4), 374-391. https://doi.org/ 10.1016/j.geomorph.2007.08.007.

Gardner, T.W., 1983. Experimental study of knickpoint and longitudinal profile evolution in cohesive, homogeneous material. Geol. Soc. Am. Bull. 94 (5), 664-672. https:// doi.org/10.1130/0016-7606(1983)94<664:ESOKAL > 2.0.CO;2.

Garrote, J., Cox, R.T., Swann, C., Ellis, M., 2006. Tectonic geomorphology of the southeastern Mississippi Embayment in northern Mississippi, USA. Geol. Soc. Am. Bull. 118 (9-10), 1160-1170. https://doi.org/10.1130/B25721.1.

Gasparini, N.M., Whipple, K.X., 2014. Diagnosing climatic and tectonic controls on topography: eastern flank of the northern Bolivian Andes. Lithosphere 6 (4), 230-250. https://doi.org/10.1130/L322.1.

Ghassemi, M.R., 2005. Drainage evolution in response to fold growth in the hanging-wall of the Khazar fault, north-eastern Alborz, Iran. Basin Res. 17 (3), 425-436. https:// doi.org/10.1111/j.1365-2117.2005.00271.x.

Giaconia, F., Booth-Rea, G., Martínez-Martínez, J.M., Azañón, J.M., Pérez-Peña, J.V., 2012. Geomorphic analysis of the Sierra Cabrera, an active pop-up in the constrictional domain of conjugate strike-slip faults: the Palomares and Polopos fault zones (eastern Betics, SE Spain). Tectonophysics 580, 27-42. https://doi.org/10.1016/j. tecto.2012.08.028.

Giamboni, M., Ustaszewski, K., Schmid, S.M., Schumacher, M.E., Wetzel, A., 2004. PlioPleistocene transpressional reactivation of Paleozoic and Paleogene structures in the Rhine-Bresse transform zone (northern Switzerland and eastern France). Int. J. Earth Sci. 93 (2), 207-223. https://doi.org/10.1007/s00531-003-0375-2.

Girish, G., Kamalamma, A.G., Jesiya, N.P., Lemoon, K., 2016. Hydro-hypsometric analysis of tropical river basins, Southwest Coast of India using geospatial technology. J. Mt Sci. 13 (5), 939-946. https://doi.org/10.1007/s11629-015-3589-4.

Golden, 2002. 2D \& 3D Data Modeling and Analysis Software. Colorado, U.S.A. Retrieved from. http://www.goldensoftware.com.

Goldrick, G., Bishop, P., 2006. Regional analysis of bedrock streamlong profiles: evaluation of Hack's SL form, and formulation and assessment of an alternative (the DS form). Earth Surf. Process. Landf. 32 (5), 649-671. https://doi.org/10.1002/esp. 1413. (2007)

Gori, S., Falcucci, E., Dramis, F., Galadini, F., Galli, P., Giaccio, B., Messina, P., Pizzi, A., Sposato, A., Cosentino, D., 2013. Deep-seated gravitational slope deformation, largescale rock failure, and active normal faulting along Mt. Morrone (Sulmona basin, Central Italy): Geomorphological and paleoseismological analyses. Geomorphology 208 (2014), 88-101. https://doi.org/10.1016/j.geomorph.2013.11.017.

Gorin, G., Signer, C., Amberger, G., 1993. Structural configuration of the western Swiss Molasse Basin as defined by reflection seismic data. Eclogae Geol. Helv. 86 (3),
693-716. https://doi.org/10.5169/seals-167259.

Grauch, V.J.S., Drenth, B.J., 2009. High-resolution aeromagnetic survey to image shallow faults, Poncha Springs and vicinity. In: Open-File Report 2009-1156. U.S. Geological Survey, Chaffee County, Colorado.

Gruber, M., 2017. Structural Investigations of the Western Swiss Molasse Basin -From 2D Seismic Interpretation to a 3D Geological Model (Doctoral dissertation). University of Fribourg, Switzerland.

Gudmundsson, G.H., 1994. An order-of-magnitude estimate of the current uplift-rates in Switzerland caused by the Würm Alpine deglaciation. Eclogae Geol. Helv. 87 (2), 545-557. https://doi.org/10.5169/seals-167470.

Guy, A., Schulmann, K., Munschy, M., Miehe, J., Edel, J., Lexa, O., Fairhead, D., 2014 Geophysical constraints for terrane boundaries in southern Mongolia. Journal of Geophysical Research: Solid Earth 119 (10), 7966-7991. https://doi.org/10.1002/ 2014JB011026.

Hack, J.T., 1973. Stream-profile analysis and stream-gradient index. Journal of Research of the U.S. Geological Survey 1 (4), 421-429. Retrieved from. http://pubs.er.usgs. gov/publication/70161653.

Harkins, N.W., Anastasio, D.J., Pazzaglia, F.J., 2005. Tectonic geomorphology of the Red Rock fault, insights into segmentation and landscape evolution of a developing range front normal fault. J. Struct. Geol. 27 (11), 1925-1939. https://doi.org/10.1016/j. jsg. 2005.07.005.

Harlin, J.M., 1978. Statistical moments of the hypsometric curve and its density function. J. Int. Assoc. Math. Geol. 10 (1), 59-72. https://doi.org/10.1007/BF01033300.

Hartley, R.A., Roberts, G.G., White, N., Richardson, C., 2011. Transient convective uplift of an ancient buried landscape. Nat. Geosci. 4 (8), 562-565. https://doi.org/10. 1038/ngeo1191.

Harvey, J.E., Burbank, D.W., Bookhagen, B., 2015. Along-strike changes in Himalayan thrust geometry: topographic and tectonic discontinuities in western Nepal. Lithosphere 7 (5), 511-518. https://doi.org/10.1130/L444.1.

Hayakawa, Y.S., Oguchi, T., 2006. DEM-based identification of fluvial knickzones and its application to Japanese mountain rivers. Geomorphology 78 (1-2), 90-106. https:// doi.org/10.1016/j.geomorph.2006.01.018.

Hoke, G.D., Isacks, B.L., Jordan, T.E., Blanco, N., Tomlinson, A.J., Ramezani, J., 2007. Geomorphic evidence for post-10 Ma uplift of the western flank of the central Andes $18^{\circ} 30^{\prime}-22^{\circ}$ S. Tectonics 26 (5), TC5021. https://doi.org/10.1029/2006TC002082.

Hurtrez, J.-E., Lucazeau, F., 1999. Lithological control on relief and hypsometry in the Hérault drainage basin (France). Comptes Rendus de l'Académie Des Sciences - Series IIA- Earth and Planetary Science 328 (10), 687-694. https://doi.org/10.1016/S12518050(99)80178-5.

Hurtrez, J., Lucazeau, F., Lavé, J., Avouac, J., 1999a. Investigation of the relationships between basin morphology, tectonic uplift, and denudation from the study of an active fold belt in the Siwalik Hills, central Nepal. Journal of Geophysical Research: Solid Earth 104 (B6), 12779-12796. https://doi.org/10.1029/1998JB900098.

Hurtrez, J.-E., Sol, C., Lucazeau, F., 1999b. Effect of drainage area on hypsometry from an analysis of small-scale drainage basins in the Siwalik Hills (Central Nepal). Earth Surf. Process. Landf. 24 (9), 799-808. https://doi.org/10.1002/(SICI)1096-9837(199908) 24:9<799::AID-ESP12>3.0.CO;2-4

Ibanez, D.M., Riccomini, C., de Miranda, F.P., 2014. Geomorphological evidence of recent tilting in the Central Amazonia Region. Geomorphology 214, 378-387. https://doi. org/10.1016/j.geomorph.2014.02.019.

Ibele, T., 2011. Tectonics of the Western Swiss Molasse Basin During Cenozoic Time (Doctoral dissertation). Retrieved from digital library rero doc. https://doc.rero.ch/ record/28382University of Fribourg, Switzerland.

Ivy-Ochs, S., Kerschner, H., Schlüchter, C., 2006. Cosmogenic nuclides and the dating of Lateglacial and Early Holocene glacier variations: the Alpine perspective. Quat. Int. 164-165 (2007), 53-63. https://doi.org/10.1016/j.quaint.2006.12.008.

Jackson, J., Van Dissen, R., Berryman, K., 1998. Tilting of active folds and faults in the Manawatu region, New Zealand: evidence from surface drainage patterns. N. Z. J. Geol. Geophys. 41 (4), 377-385. https://doi.org/10.1080/00288306.1998.9514817.

Jibson, R.W., 1996. Use of landslides for paleoseismic analysis. Eng. Geol. 43 (4), 291-323. https://doi.org/10.1016/S0013-7952(96)00039-7.

Kahle, H.-G., Geiger, A., Buerki, B., Gubler, E., Marti, U., Wirth, B., Rothacher, M. Gurtner, W., Beutler, G., Bauersima, I., Pfiffner, O.A., 1997. Recent crustal movements, geoid and density distribution; contribution from integrated satellite and terrestrial measurements. In: Pfiffner, O.A. (Ed.), Results of NRP 20; Deep Structure of the Swiss Alps. Birkhaeuser, Basel, Switzerland, pp. 251-259.

Kale, V.S., Sengupta, S., Achyuthan, H., Jaiswal, M.K., 2013. Tectonic controls upon Kaveri River drainage, cratonic Peninsular India: Inferences from longitudinal profiles, morphotectonic indices, hanging valleys and fluvial records. Geomorphology 227, 153-165. https://doi.org/10.1016/j.geomorph.2013.07.027.

Keller, E.A., Pinter, N., 2002. Active Tectonics: Earthquakes, Uplift and Landscape. Active Tectonics: Earthquakes, Uplift and Landscape. Prentice Hall, Upper Saddle River, New Jersey.

Kelly, M.A., Buoncristiani, J.-F., Schlüchter, C., 2004. A reconstruction of the last glacial maximum (LGM) ice-surface geometry in the western Swiss Alps and contiguous Alpine regions in Italy and France. Eclogae Geol. Helv. 97 (1), 57-75. https://doi org/10.1007/s00015-004-1109-6.

Kirby, E., Whipple, K.X., 2012. Expression of active tectonics in erosional landscapes. J. Struct. Geol. 44, 54-75. https://doi.org/10.1016/j.jsg.2012.07.009.

Kirby, E., Whipple, K.X., Tang, W., Chen, Z., 2003. Distribution of active rock uplift along the eastern margin of the Tibetan Plateau: inferences from bedrock channel longitudinal profiles. J. Geophys. Res. 108 (B4), 2217. https://doi.org/10.1029/ 2001JB000861.

Kley, J., Voigt, T., 2008. Late Cretaceous intraplate thrusting in central Europe: effect of Africa-Iberia-Europe convergence, not Alpine collision. Geology 36 (11), 839-842. https://doi.org/10.1130/G24930A.1. 
Klingelé, E.E., 1992. Gravimetry and aeromagnetics in the Swiss Molasse Basin. Eclogae Geol. Helv. 85 (3), 767. https://doi.org/10.5169/seals-167033.

Klingelé, E., Olivier, R., 1980. La nouvelle carte gravimétrique de la Suisse (anomalie de Bouguer). Geophysique 20 (Commission Swiss de Géophysique).

Klingelé, E.E., Verdun, J., 2003. A new interpretation of the Chasseral magnetic anomaly (Swiss Jura). Eclogae Geol. Helv. 96 (2), 249-259. https://doi.org/10.1007/S00015003-1084-3.

Korup, O., 2006. Rock-slope failure and the river long profile. Geology 34 (1), 45-48. https://doi.org/10.1130/G21959.1.

Korup, O., Schlunegger, F., 2008. Rock-type control on erosion-induced uplift, eastern Swiss Alps. Earth Planet. Sci. Lett. 278 (3-4), 278-285. https://doi.org/10.1016/j. epsl.2008.12.012.

Korup, O., Strom, A.L., Weidinger, J.T., 2006. Fluvial response to large rock-slope failures: examples from the Himalayas, the Tien Shan, and the Southern Alps in New Zealand. Geomorphology 78 (1-2), 3-21. https://doi.org/10.1016/j.geomorph.2006. 01.020 .

Korup, O., Densmore, A.L., Schlunegger, F., 2010. The role of landslides in mountain range evolution. Geomorphology 120 (1-2), 77-90. https://doi.org/10.1016/j. geomorph.2009.09.017.

Kühni, A., Pfiffner, O., 2001. The relief of the Swiss Alps and adjacent areas and its relation to lithology and structure: topographic analysis from a 250-m DEM. Geomorphology 41 (4), 285-307. https://doi.org/10.1016/S0169-555X(01)00060-5.

Larue, J.-P., 2007. Tectonic influences on the Quaternary drainage evolution on the north-western margin of the French Central Massif: the Creuse valley example. Geomorphology 93 (3-4), 398-420. https://doi.org/10.1016/j.geomorph.2006.11. 014. (2008).

Laubscher, H.P., 1986. The eastern Jura: relations between thin-skinned and basement tectonics, local and regional. Geol. Rundsch. 75 (3), 535-553. https://doi.org/10. 1007/BF01820630.

Laubscher, H., 1992. Jura kinematics and the Molasse Basin. Eclogae Geol. Helv. 85 (3), 653-675. https://doi.org/10.5169/seals-167024.

Leeder, M.R., Jackson, J.A., 1993. The interaction between normal faulting and drainage in active extensional basins, with examples from the western United States and central Greece. Basin Res. 5 (2), 79-102. https://doi.org/10.1111/j.1365-2117.1993. tb00059.x.

Lemeille, F., Cushing, M.E., Carbon, D., Grellet, B., Bitterli, T., Fle'hoc, C., Innocent, C., 1999. Co-seismic ruptures and deformations recorded by speleothems in the epicentral zone of the Basle earthquake. Geodin. Acta 12 (3-4), 179-191. https://doi. org/10.1080/09853111.1999.11105341.

Li, Y., Oldenburg, D.W. 1998. Separation of regional and residual magnetic field data. Geophysics 63 (2), 431-439. https://doi.org/10.1190/1.1444343.

Li, Y., Zhou, R., Zhao, G., Li, H., Su, D., Ding, H., Yan, Z., Yan, L., Yun, K., Ma, C., 2014. Tectonic uplift and landslides triggered by the Wenchuan earthquake and constraints on orogenic growth: a case study from Hongchun Gully, Longmen Mountains, Sichuan, China. Quat. Int. 349, 142-152. https://doi.org/10.1016/j.quaint.2014.05. 005.

Lifton, N.A., Chase, C.G., 1992. Tectonic, climatic and lithologic influences on landscape fractal dimension and hypsometry: implications for landscape evolution in the San Gabriel Mountains, California. Geomorphology 5 (1-2), 77-114. https://doi.org/10. 1016/0169-555X(92)90059-W.

Liu, X., Zhang, Z., 2011. Drainage network extraction using LiDAR-derived DEM in volcanic plains. Area 43 (1), 42-52. https://doi.org/10.1111/j.1475-4762.2010. 00955.x.

u, H., Wu, D., Cheng, L., Zhang, T., Xiong, J., Zheng, X., Li, Y., 2017. Late Quaternary drainage evolution in response to fold growth in the northern Chinese Tian Shan foreland. Geomorphology 299, 12-23. https://doi.org/10.1016/j.geomorph.2017. 09.037.

Luo, W., 2000. Quantifying groundwater-sapping landforms with a hypsometric technique. Journal of Geophysical Research: Planets 105 (E1), 1685-1694. https://doi. org/10.1029/1999JE001096.

Luo, W., 2002. Hypsometric analysis of Margaritifer Sinus and origin of valley networks. J. Geophys. Res. 107 (E10), 5071. https://doi.org/10.1029/2001JE001500.

Madritsch, H., Schmid, S.M., Fabbri, O., 2008. Interactions between thin- and thickskinned tectonics at the northwestern front of the Jura fold-and-thrust belt (eastern France). Tectonics 27 (5). https://doi.org/10.1029/2008TC002282.

Madritsch, H., Fabbri, O., Hagedorn, E.-M., Preusser, F., Schmid, S.M., Ziegler, P.A., 2009. Feedback between erosion and active deformation: geomorphic constraints from the frontal Jura fold-and-thrust belt (eastern France). Int. J. Earth Sci. 99 (S1), 103-122. https://doi.org/10.1007/s00531-009-0468-7.

Madritsch, H., Preusser, F., Fabbri, O., Bichet, V., Schlunegger, F., Schmid, S.M., 2010 Late Quaternary folding in the Jura Mountains: evidence from syn-erosional deformation of fluvial meanders. Terra Nova 22 (2), 147-154. https://doi.org/10. 1111/j.1365-3121.2010.00928.x.

Mahmood, S.A., Gloaguen, R., 2011. Appraisal of active tectonics in Hindu Kush: Insights from DEM derived geomorphic indices and drainage analysis. Geosci. Front. 3 (4), 407-428. https://doi.org/10.1016/j.gsf.2011.12.002.

Maidment, D.R., 2002. ArcHydro: GIS for Water Resources. ESRI Press, Redlands, California, USA.

Malik, J.N., Mohanty, C., 2006. Active tectonic influence on the evolution of drainage and landscape: geomorphic signatures from frontal and hinterland areas along the Northwestern Himalaya, India. J. Asian Earth Sci. 29 (5-6), 604-618. https://doi. org/10.1016/j.jseaes.2006.03.010.

Marschall, I., Deichmann, N., Marone, F., 2013. Earthquake focal mechanisms and stress orientations in the eastern Swiss Alps. Swiss J. Geosci. 106 (1), 79-90. https://doi. org/10.1007/s00015-013-0129-5.

Mathew, M.J., Menier, D., Siddiqui, N., Kumar, S.G., Authemayou, C., 2016. Active tectonic deformation along rejuvenated faults in tropical Borneo: inferences obtained from tectono-geomorphic evaluation. Geomorphology 267, 1-15. https://doi.org/10. 1016/j.geomorph.2016.05.016.

Matzenauer, E., 2012. Tectonics of the Préalpes Klippen and the Subalpine Molasse (Canton Fribourg, Switzerland) (Doctoral dissertation). Retrieved from digital library rero doc. http://doc.rero.ch/record/32247University of Fribourg, Switzerland.

Maurer, H.R., Burkhard, M., Deichmann, N., Green, A.G., 1997. Active tectonism in the central Alps: contrasting stress regimes north and south of the Rhone Valley. Terra Nova 9 (2), 91-94. https://doi.org/10.1111/j.1365-3121.1997.tb00010.x.

Mayer, L., 1986. Tectonic geomorphology of escarpments and mountain fronts. In: Wallace, R.E. (Ed.), Active Tectonics, Studies in Geophysics. National Academy Press, Washington, DC, pp. 125-135.

McKeown, F.A., Jones-Cecil, M., Askew, B.L., McGrath, M.B., 1988. In: Geological Survey Bulletin, U.S. (Ed.), Analysis of stream-profile data and inferred tectonic activity, eastern Ozark Mountains region. CO: U.S. Government Printing Office, Denver. https://pubs.er.usgs.gov/publication/b1807.

McMaster, K.J., 2002. Effects of digital elevation model resolution on derived stream network positions. Water Resources Research 38 (4). https://doi.org/10.1029/ 2000WR000150. 13-1-13-8.

Meier, B.P., 2010. Ergänzende Interpretation reflexionsseismischer Linien zwischen dem östlichen und westlichen Molassebecken. NAGRA Arbeitsbericht, pp. 10-40.

Merritts, D., Vincent, K.R., 1989. Geomorphic response of coastal streams to low, intermediate, and high rates of uplift, Medocino triple junction region, northern California. Geol. Soc. Am. Bull. 101 (11), 1373-1388. https://doi.org/10.1130/00167606(1989)101 < 1373:GROCST > 2.3.CO;2.

Mey, J., Scherler, D., Wickert, A.D., Egholm, D.L., Tesauro, M., Schildgen, T.F., Strecker, M.R., 2016. Glacial isostatic uplift of the European Alps. Nat. Commun. 7, 1-9. https://doi.org/10.1038/ncomms13382.

Mickus, K.L., Hinojosa, J.H., 2001. The complete gravity gradient tensor derived from the vertical component of gravity: a Fourier transform technique. J. Appl. Geophys. 46 (3), 159-174. https://doi.org/10.1016/S0926-9851(01)00031-3.

Miller, J.R., 1991. The influence of bedrock geology on knickpoint development and channel-bed degradation along downcutting streams in South-Central Indiana. The Journal of Geology 99 (4), 591-605. https://doi.org/10.1086/629519.

Mock, S., Herwegh, M., 2017. Tectonics of the central Swiss Molasse Basin: post-Miocene transition to incipient thick-skinned tectonics? Tectonics 36 (9), 1699-1723. https:// doi.org/10.1002/2017TC004584.

Mock, S., von Hagke, C., Schlunegger, F., Dunkl, I., Herwegh, M., 2019. Late Miocene thrusting in the North Alpine foreland: driven by a deep-seated process and shaped by the local mechanical stratigraphy. Solid Earth Discussions. https://doi.org/10.5194/ se-2019-56.

Monecke, K., Anselmetti, F.S., Becker, A., Schnellmann, M., Sturm, M., Giardini, D., 2006. Earthquake-induced deformation structures in lake deposits: a Late Pleistocene to Holocene paleoseismic record for Central Switzerland. Eclogae Geol. Helv. 99 (3), 343-362. https://doi.org/10.1007/s00015-006-1193-x.

Montgomery, D.R., Balco, G., Willett, S.D., 2001. Climate, tectonics, and the morphology of the Andes. Geology 29 (7), 579-582. https://doi.org/10.1130/0091-7613(2001) 029<0579:CTATMO > 2.0.CO;2.

Mosar, J., 1999. Present-day and future tectonic underplating in the western Swiss Alps: reconciliation of basement/wrench-faulting and décollement folding of the Jura and Molasse basin in the Alpine foreland. Earth Planet. Sci. Lett. 173 (3), 143-155. https://doi.org/10.1016/S0012-821X(99)00238-1.

Nigel, R., Rughooputh, S.D.D.V., 2010. Soil erosion risk mapping with new datasets: an improved identification and prioritisation of high erosion risk areas. Catena 82 (3), 191-205. https://doi.org/10.1016/j.catena.2010.06.005.

Norton, K.P., Abbühl, L.M., Schlunegger, F., 2010a. Glacial conditioning as an erosional driving force in the Central Alps. Geology 38 (7), 655-658. https://doi.org/10.1130/ G31102.1.

Norton, K.P., von Blanckenburg, F., Kubik, P.W., 2010b. Cosmogenic nuclide-derived rates of diffusive and episodic erosion in the glacially sculpted upper Rhone Valley, Swiss Alps. Earth Surf. Process. Landf. 35 (6), 651-662. https://doi.org/10.1002/esp. 1961.

Nunes, F.C., Delunel, R., Schlunegger, F., Akçar, N., Kubik, P.W., 2015. Bedrock bedding, landsliding and erosional budgets in the Central European Alps. Terra Nova 27 (5), 370-378. https://doi.org/10.1111/ter.12169.

O'Callaghan, J.F., Mark, D.M., 1984. The extraction of drainage networks from digital elevation data. Computer Vision, Graphics, and Image Processing 28 (3), 323-344. https://doi.org/10.1016/S0734-189X(84)80011-0.

Ohmori, H., 1993. Changes in the hypsometric curve through mountain building resulting from concurrent tectonics and denudation. Geomorphology 8 (4), 263-277. https:// doi.org/10.1016/0169-555X(93)90023-U.

Omvir, S., Sarangi, A., 2008. Hypsometric analysis of the lesser Himalayan watersheds using geographical information system. Indian Journal of Soil Conservation 36 (3), 148-154. Retrieved from. http://www.indianjournals.com/ijor.aspx?target $=$ ijor:ijsc\&volume $=36 \&$ issue $=3 \&$ article $=006$.

Ortner, H., Aichholzer, S., Zerlauth, M., Pilser, R., Fügenschuh, B., 2015. Geometry, amount, and sequence of thrusting in the Subalpine Molasse of western Austria and southern Germany, European Alps. Tectonics 34 (1), 1-30. https://doi.org/10.1002/ 2014 TC003550.

Ouchi, S., 1985. Response of alluvial rivers to slow active tectonic movement. Geol. Soc. Am. Bull. 96 (4), 504-515. https://doi.org/10.1130/0016-7606(1985) $96<504$ :ROARTS $>2.0 . \mathrm{CO} ; 2$

Ouimet, W.B., 2009. Landslides associated with the May 12, 2008 Wenchuan earthquake: implications for the erosion and tectonic evolution of the Longmen Shan. Tectonophysics 491 (1-4), 244-252. https://doi.org/10.1016/j.tecto.2009.09.012.

Ouimet, W.B., Whipple, K.X., Granger, D.E., 2009. Beyond threshold hillslopes: channel 
adjustment to base-level fall in tectonically active mountain ranges. Geology 37 (7), 579-582. https://doi.org/10.1130/G30013A.1.

Palacios-Vélez, O.L., Cuevas-Renaud, B., 1986. Automated river-course, ridge and basin delineation from digital elevation data. J. Hydrol. 86 (3-4), 299-314. https://doi. org/10.1016/0022-1694(86)90169-1.

Pedrera, A., Perez-Peña, J.V., Galindo-Zaldivar, J., Azañon, J.M., Azor, A., 2009. Testing the sensitivity of geomorphic indices in areas of low-rate active folding (eastern Betic Cordillera, Spain). Geomorphology 105 (3-4), 218-231. https://doi.org/10.1016/j. geomorph.2008.09.026.

Pérez-Peña, J.V., Azañón, J.M., Azor, A., 2008a. CalHypso: an ArcGIS extension to calculate hypsometric curves and their statistical moments. Applications to drainage basin analysis in SE Spain. Comput. Geosci. 35 (6), 1214-1223. https://doi.org/10. 1016/j.cageo.2008.06.006.

Pérez-Peña, J.V., Azañón, J.M., Azor, A., Delgado, J., González-Lodeiro, F., 2008b. Spatial analysis of stream power using GIS: SLk anomaly maps. Earth Surf. Process. Landf. 34 (1), 16-25. https://doi.org/10.1002/esp.1684.

Pérez-Peña, J.V., Azañón, J.M., Booth-Rea, G., Azor, A., Delgado, J., 2009. Differentiating geology and tectonics using a spatial autocorrelation technique for the hypsometric integral. Journal of Geophysical Research 114 (F2), F02018. https://doi.org/10 1029/2008JF001092.

Persaud, M., Pfiffner, O.A., 2004. Active deformation in the eastern Swiss Alps: postglacial faults, seismicity and surface uplift. Tectonophysics 385 (1-4), 59-84. https:// doi.org/10.1016/j.tecto.2004.04.020.

Persendt, F.C., Gomez, C., 2015. Assessment of drainage network extractions in a lowrelief area of the Cuvelai Basin (Namibia) from multiple sources: LiDAR, topographic maps, and digital aerial orthophotographs. Geomorphology 260, 32-50. https://doi. org/10.1016/j.geomorph.2015.06.047.

Peters, G., van Balen, R.T., 2007. Tectonic geomorphology of the northern Upper Rhine Graben. Germany. Global and Planetary Change 58 (1-4), 310-334. https://doi.org/ 10.1016/j.gloplacha.2006.11.041.

Pfiffner, O.A., 2014. Geology of the Alps, 2nd edition. John Wiley, Chichester, UK.

Pfiffner, O.A., Erard, P.F., Stäuble, M., 1997. Two cross sections through the Swiss Molasse Basin (lines E4-E6, W1, W7-W10). In: Pfiffner, O.A. (Ed.), Deep Structure of the Swiss Alps: Results of NRP. 20. Birkhauser, Basel, Switzerland, pp. 64-72.

Phillips, J.D., 2000. Locating magnetic contacts: a comparison of the horizontal gradient, analytic signal, and local wavenumber methods. In: SEG Technical Program Expanded Abstracts 2000, pp. 402-405. https://doi.org/10.1190/1.1816078.

Phillips, J.D., 2007. Geosoft eXecutables (GX's) Developed by the US Geological Survey, Version 2.0, With Notes on GX Development From Fortran Code. Open-File Report 2007-1355. U.S. Geological Survey, Reston, Virginia Retrieved from. https://pubs. usgs.gov/of/2007/1355/.

Pike, R.J., Wilson, S.E., 1971. Elevation-relief ratio, hypsometric integral, and geomorphic area-altitude analysis. Geol. Soc. Am. Bull. 82 (4), 1079-1084. https://doi. org/10.1130/0016-7606(1971)82[1079:ERHIAG]2.0.CO;2.

Rabin, M., Sue, C., Valla, P.G., Champagnac, J.-D., Carry, N., Bichet, V., et al., 2015. Deciphering neotectonics from river profile analysis in the karst Jura Mountains (northern Alpine foreland). Swiss J. Geosci. 108 (2-3), 401-424. https://doi.org/10. 1007/s00015-015-0200-5.

Radaideh, O.M.A., Grasemann, B., Melichar, R., Mosar, J., 2016. Detection and analysis of morphotectonic features utilizing satellite remote sensing and GIS: an example in SW Jordan. Geomorphology 275, 58-79. https://doi.org/10.1016/j.geomorph.2016.09. 033.

Ramsey, L.A., Walker, R.T., Jackson, J., 2008. Fold evolution and drainage development in the Zagros mountains of Fars province, south-east Iran. Basin Res. 20 (1), 23-48. https://doi.org/10.1111/j.1365-2117.2007.00342.x.

Rigassi, D.A., Jaccard, M., 1995. Geological Atlas of Switzerland 1:25000, Ste-Croix CN 1182. Map 95. Federal Office of Topography swisstopo, Bern.

Riquelme, R., Martinod, J., Hérail, G., Darrozes, J., Charrier, R., 2002. A geomorphological approach to determining the Neogene to Recent tectonic deformation in the Coastal Cordillera of northern Chile (Atacama). Tectonophysics 361 (3-4), 255-275. https://doi.org/10.1016/S0040-1951(02)00649-2.

Safran, E.B., Bierman, P.R., Aalto, R., Dunne, T., Whipple, K.X., Caffee, M., 2005. Erosion rates driven by channel network incision in the Bolivian Andes. Earth Surf. Process. Landf. 30 (8), 1007-1024. https://doi.org/10.1002/esp.1259.

Salcher, B.C., Kober, F., Kissling, E., Willett, S.D., 2014. Glacial impact on short-wavelength topography and long-lasting effects on the denudation of a deglaciated mountain range. Glob. Planet. Chang. 115 (2014), 59-70. https://doi.org/10.1016/j. gloplacha.2014.01.002.

Salvany, J.M., 2004. Tilting neotectonics of the Guadiamar drainage basin, SW Spain. Earth Surf. Process. Landf. 29 (2), 145-160. https://doi.org/10.1002/esp.1005.

Sboras, S., Ganas, A., Pavlides, S., 2010. Morphotectonic analysis of the neotectonic and active faults of Beotia (Central Greece), using G.I.S. techniques. Bull. Geol. Soc. Greece 43 (3), 1607-1618. https://doi.org/10.12681/bgsg.11335.

Schlatter, A., Schneider, D., Geiger, A., Kahle, H., 2004. Recent vertical movements from precise levelling in the vicinity of the city of Basel, Switzerland. Int. J. Earth Sci. 94 (4), 507-514. https://doi.org/10.1007/s00531-004-0449-9.

Schlunegger, F., 2002. Impact of hillslope-derived sediment supply on drainage basin development in small watersheds at the northern border of the central Alps of Switzerland. Geomorphology 46 (3-4), 285-305. https://doi.org/10.1016/S0169555X(02)00081-8.

Schlunegger, F., Hinderer, M., 2002. Crustal uplift in the Alps: why the drainage pattern matters. Terra Nova 13 (6), 425-432. https://doi.org/10.1046/j.1365-3121.2001. 00374.x.

Schlunegger, F., Hinderer, M., 2003. Pleistocene/Holocene climate change, re-establishment of fluvial drainage network and increase in relief in the Swiss Alps. Terra Nova 15 (2), 88-95. https://doi.org/10.1046/j.1365-3121.2003.00469.x.
Schlunegger, F., Norton, K.P., 2013. Water versus ice: the competing roles of modern climate and Pleistocene glacial erosion in the Central Alps of Switzerland. Tectonophysics 602, 370-381. https://doi.org/10.1016/j.tecto.2013.03.027.

Schlunegger, F., Jordan, T.E., Klaper, E.M., 1997a. Controls of erosional denudation in the orogen on foreland basin evolution: the Oligocene central Swiss Molasse Basin as an example. Tectonics 16 (5), 823-840. https://doi.org/10.1029/97TC01657.

Schlunegger, F., Matter, A., Burbank, D.W., Klaper, E.M., 1997b. Magnetostratigraphic constraints on relationships between evolution of the central Swiss Molasse basin and Alpine orogenic events. Geol. Soc. Am. Bull. 109 (2), 225-241. https://doi.org/10. 1130/0016-7606(1997)109<0225:MCORBE > 2.3.CO;2.

Schlunegger, F., Norton, K., Zeilinger, G., 2011. Climate forcing on channel profiles in the Eastern Cordillera of the Coroico region, Bolivia. J. Geol. 119 (1), 97-107. https:// doi.org/10.1086/657407.

Schmid, S.M., Pfiffner, O.A., Froitzheim, N., Schönborn, G., Kissling, E., 1996 Geophysical-geological transect and tectonic evolution of the Swiss- Italian Alps. Tectonics 15 (5), 1036-1064. https://doi.org/10.1029/96TC00433.

Seeber, L., Gornitz, V., 1983. River profiles along the Himalayan arc as indicators of active tectonics. Tectonophysics 92 (4), 335-367. https://doi.org/10.1016/00401951(83)90201-9.

Selvakumar, R., Ramasamy, S., 2014. Evaluating influence of active tectonics on spatial distribution pattern of floods along eastern Tamil Nadu, India. Geomorphology 226 (1), 25-34. https://doi.org/10.1016/j.geomorph.2014.07.024.

Signer, C., Gorin, G.E., 1995. New geological observations between the Jura and the Alps in the Geneva area, as derived from reflection seismic data. Eclogae Geol. Helv. 88 (2), 235-265. https://doi.org/10.5169/seals-167674.

Snyder, N.P., Whipple, K.X., Tucker, G.E., Merritts, D.J., 2000. Landscape response to tectonic forcing: digital elevation model analysis of stream profiles in the Mendocino triple junction region, northern California. Geol. Soc. Am. Bull. 112 (8), 1250-1263. https://doi.org/10.1130/0016-7606(2000)112<1250:LRTTFD > 2.0.CO;2.

Sommaruga, A., 1997. Geology of the Central Jura and the Molasse Basin. Doctoral dissertation). Retrieved from digital library rero doc. https://doc.rero.ch/record/ 4381 ? ln = enUniversity of Neuchâtel, Switzerland.

Sommaruga, A., 1999. Décollement tectonics in the Jura foreland fold-and-thrust belt. Mar. Pet. Geol. 16 (2), 111-134. https://doi.org/10.1016/S0264-8172(98)00068-3.

Sommaruga, A., 2011. From the central Jura mountains to the molasse basin (France and Switzerland). Swiss Bulletin Fuer Angewandte Geologie 16 (2), 63-75. https://doi. org $/ 10.5169 /$ seals-327746.

Sternai, P., Herman, F., Fox, M.R., Castelltort, S., 2011. Hypsometric analysis to identify spatially variable glacial erosion. J. Geophys. Res. 116 (F3) https://doi.org/10.1029/ 2010JF001823.

Strahler, A.N., 1952. Hypsometric area-altitude analysis of erosional topography. Geol. Soc. Am. Bull. 63 (11), 1117-1142. https://doi.org/10.1130/0016-7606(1952) 63[1117:HAAOET]2.0.CO;2.

Stutenbecker, L.A., Costa, A., Schlunegger, F., 2015. Patterns of landscape form in the upper Rhône basin, Central Swiss Alps, predominantly show lithologic controls despite multiple glaciations and variations in rock uplift rates. Earth Surface Dynamics Discussions 3 (4), 1061-1105. https://doi.org/10.5194/esurfd-3-1061-2015.

Stutenbecker, L., Costa, A., Schlunegger, F., 2016. Lithological control on the landscape form of the upper Rhône Basin, Central Swiss Alps. Earth Surface Dynamics 4 (1), 253-272. https://doi.org/10.5194/esurf-4-253-2016.

Tarboton, D.G., 1997. A new method for the determination of flow directions and upslope areas in grid digital elevation models. Water Resour. Res. 33 (2), 309-319. https:// doi.org/10.1029/96WR03137.

Thompson, S.D., 1967. Estimation of Regional Trends in Gravity Using Gram Orthogonal Polynomials (Master's thesis). Retrieved from Scholars' Mine. http://scholarsmine. mst.edu/masters_theses/5215University of Missouri at Rolla, Missouri, Rolla.

Trauerstein, M., Norton, K.P., Preusser, F., Schlunegger, F., 2013. Climatic imprint on landscape morphology in the western escarpment of the Andes. Geomorphology 194, 76-83. https://doi.org/10.1016/j.geomorph.2013.04.015.

Troiani, F., Seta, M.D., 2008. The use of the Stream Length-Gradient index in morphotectonic analysis of small catchments: a case study from Central Italy. Geomorphology 102 (1), 159-168. https://doi.org/10.1016/j.geomorph.2007.06. 020 .

Troiani, F., Galve, J.P., Piacentini, D., Seta, M.D., Guerrero, J., 2014. Spatial analysis of stream length-gradient (SL) index for detecting hillslope processes: a case of the Gállego River headwaters (Central Pyrenees, Spain). Geomorphology 214, 183-197. https://doi.org/10.1016/j.geomorph.2014.02.004.

Troiani, F., Piacentini, D., Seta, M.D., Galve, J.P., 2017. Stream Length-gradient Hotspot and Cluster Analysis (SL-HCA) to fine-tune the detection and interpretation of knickzones on longitudinal profiles. Catena 156, 30-41. https://doi.org/10.1016/j. catena.2017.03.015.

Tsodoulos, I.M., Koukouvelas, I.K., Pavlides, S., 2008. Tectonic geomorphology of the easternmost extension of the Gulf of Corinth (Beotia, Central Greece). Tectonophysics 453 (1-4), 211-232. https://doi.org/10.1016/j.tecto.2007.06.015.

Tucker, G.E., Slingerland, R., 1996. Predicting sediment flux from fold and thrust belts. Basin Res. 8 (3), 329-349. https://doi.org/10.1046/j.1365-2117.1996.00238.x.

Turcotte, R., Fortin, J.-P., Rousseau, A., Massicotte, S., Villeneuve, J.-P., 2000. Determination of the drainage structure of a watershed using a digital elevation model and a digital river and lake network. J. Hydrol. 240 (3-4), 225-242. https:// doi.org/10.1016/S0022-1694(00)00342-5.

Ul-Hadi, S., Khan, S.D., Owen, L.A., Khan, A.S., 2012. Geomorphic response to an active transpressive regime: a case study along the Chaman strike-slip fault, western Pakistan. Earth Surf. Process. Landf. 38 (3), 250-264. https://doi.org/10.1002/esp. 3272.

Ustaszewski, M., Pfiffner, O.A., 2008. Neotectonic faulting, uplift and seismicity in the central and western Swiss Alps. In: Siegesmund, S., Fügenschuh, B., Froitzheim, N. 
(Eds.), Tectonic Aspects of the Alpine-Dinaride-Carpathian System. Geological Society, London, Special Publications, vol. 298. pp. 231-249. https://doi.org/10. 1144/SP298.12.

Valla, P.G., Shuster, D.L., van Der Beek, P.A., 2011. Significant increase in relief of the European Alps during mid-Pleistocene glaciations. Nat. Geosci. 4, 688-692. https:// doi.org/10.1038/NGEO1242.

von Hagke, C., Cederbom, C.E., Oncken, O., Stöckli, D.F., Rahn, M.K., Schlunegger, F. 2012. Linking the northern Alps with their foreland: the latest exhumation history resolved by low-temperature thermochronology. Tectonics 31 (5). https://doi.org/ 10.1029/2011TC003078.

Vernon, A.J., van der Beek, P., Sinclair, H.D., 2009. Spatial correlation between long-term exhumation rates and present-day parameters in the western European Alps. Geology 37 (9), 859-862. https://doi.org/10.1130/G25740A.1.

Vojtko, R., Petro, L., Benová, A., Bóna, J., Hók, J., 2011. Neotectonic evolution of the northern Laborec drainage basin (northeastern part of Slovakia). Geomorphology 138 (1), 276-294. https://doi.org/10.1016/j.geomorph.2011.09.012.

Walker, R., Ramsey, L., Jackson, J., 2011. Geomorphic evidence for ancestral drainage patterns in the Zagros Simple Folded Zone and growth of the Iranian plateau. Geol. Mag. 148 (5-6), 901-910. https://doi.org/10.1017/S0016756811000185.

Weidmann, M., Dorthe, J.P., Emmenegger, C., 2002. Geological Atlas of Switzerland 1:25000, Rossens CN 1205. Map 105, Federal Office of Topography swisstopo, Bern.

Whipple, K.X., 2004. Bedrock rivers and the geomorphology of active orogens. Annu. Rev. Earth Planet. Sci. 32 (1), 151-185. https://doi.org/10.1146/annurev.earth.32. 101802.120356.

Whipple, K.X., 2009. Erratum: the influence of climate on the tectonic evolution of mountain belts. Nat. Geosci. 2 (10), 97-104. https://doi.org/10.1038/ngeo638.

Whipple, K.X., Gasparini, N.M., 2014. Tectonic control of topography, rainfall patterns, and erosion during rapid post-12 Ma uplift of the Bolivian Andes. Lithosphere 6 (4), 251-268. https://doi.org/10.1130/L325.1.

Whipple, K.X., Tucker, G.E 1999. Dynamics of the stream-power river incision model: Implications for height limits of mountain ranges, landscape response timescales, and research needs. Journal of Geophysical Research: Solid Earth 104 (B8),
17661-17674. https://doi.org/10.1029/1999JB900120.

Whittaker, A.C., 2012. How do landscapes record tectonics and climate? Lithosphere 4 (2), 160-164. https://doi.org/10.1130/RF.L003.1.

Willett, S.D., Schlunegger, F., Picotti, V., 2006. Messinian climate change and erosional destruction of the central European Alps. Geology 34 (8), 613-616. https://doi.org/ $10.1130 / \mathrm{G} 22280.1$

Willgoose, G., Hancock, G., 1998. Revisiting the hypsometric curve as an indicator of form and process in transport-limited catchment. Earth Surf. Process. Landf. 23 (7), 611-623. https://doi.org/10.1002/(SICI)1096-9837(199807)23:7<611::AIDESP872 > 3.0.CO;2-Y.

Wirsig, C., Zasadni, J., Ivy-Ochs, S., Christl, M., Kober, F., Schlüchter, C., 2016. A deglaciation model of the Oberhasli, Switzerland. J. Quat. Sci. 31 (1), 46-59. https:// doi.org/10.1002/jqs.2831.

Wittmann, H., von Blanckenburg, F., Kruesmann, T., Norton, K. P., \& Kubik, P. W. (2007). Relation between rock uplift and denudation from cosmogenic nuclides in river sediment in the Central Alps of Switzerland. J. Geophys. Res., 112, F04010, https://doi. org/10.1029/2006JF000729.

Wobus, C., Whipple, K., Kirby, E., Snyder, N.P., Johnson, J., Spyropolou, K., Crosby, B., Sheehan, D., 2006. Tectonics from topography: procedure, promise and pitfalls. In: Willett, S.D., Hovius, N., Brandon, M.T., Fisher, D.M. (Eds.), Tectonics, Climate, and Landscape Evolution. 398. Geological Society of America, pp. 55-74. https://doi. org/10.1130/2006.2398(04.

Zeng, H., 1989. Estimation of the degree of polynomial fitted to gravity anomalies and its application. Geophys. Prospect. 37 (8), 959-973. https://doi.org/10.1111/j.13652478.1989.tb02242.x.

Ziegler, P.A., 1987. Late Cretaceous and Cenozoic intra-plate compressional deformations in the Alpine foreland-a geodynamic model. Tectonophysics 137 (1-4), 389-420. https://doi.org/10.1016/0040-1951(87)90330-1.

Ziegler, P.A., Cloetingh, S., van Wees, J.-D., 1995. Dynamics of intra-plate compressional deformation: the Alpine foreland and other examples. Tectonophysics 252 (1-4), 7-59. https://doi.org/10.1016/0040-1951(95)00102-6. 